\title{
TVA Coal-Fired Plant Potential for Advanced Reactor Siting
}

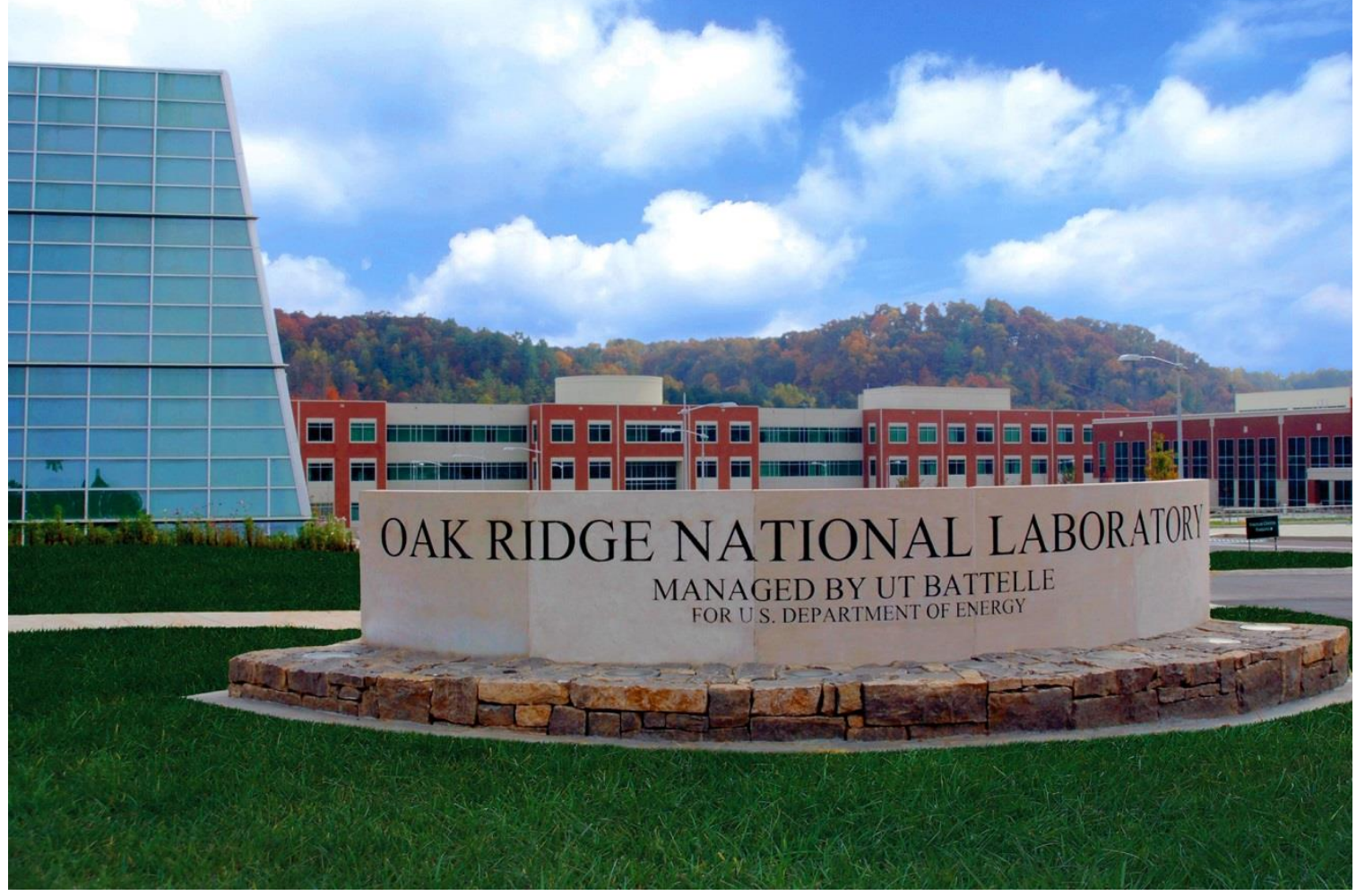
R. Belles
O. Omitaomu
A. Worrall

September 2021 


\title{
DOCUMENT AVAILABILITY
}

Reports produced after January 1, 1996, are generally available free via US Department of Energy (DOE) SciTech Connect.

Website www.osti.gov

Reports produced before January 1, 1996, may be purchased by members of the public from the following source:

\author{
National Technical Information Service \\ 5285 Port Royal Road \\ Springfield, VA 22161 \\ Telephone 703-605-6000 (1-800-553-6847) \\ TDD 703-487-4639 \\ Fax 703-605-6900 \\ E-mail info@ntis.gov \\ Website http://classic.ntis.gov/
}

Reports are available to DOE employees, DOE contractors, Energy Technology Data Exchange representatives, and International Nuclear Information System representatives from the following source:

Office of Scientific and Technical Information

PO Box 62

Oak Ridge, TN 37831

Telephone 865-576-8401

Fax 865-576-5728

E-mail reports@osti.gov

Website https://www.osti.gov/

This report was prepared as an account of work sponsored by an agency of the United States Government. Neither the United States Government nor any agency thereof, nor any of their employees, makes any warranty, express or implied, or assumes any legal liability or responsibility for the accuracy, completeness, or usefulness of any information, apparatus, product, or process disclosed, or represents that its use would not infringe privately owned rights. Reference herein to any specific commercial product, process, or service by trade name, trademark, manufacturer, or otherwise, does not necessarily constitute or imply its endorsement, recommendation, or favoring by the United States Government or any agency thereof. The views and opinions of authors expressed herein do not necessarily state or reflect those of the United States Government or any agency thereof. 
Nuclear Energy and Fuel Cycle Division Computational Sciences and Engineering Division

TVA COAL-FIRED PLANT POTENTIAL FOR ADVANCED REACTOR SITING

R. Belles

O. Omitaomu

A. Worrall

September 2021

Prepared by OAK RIDGE NATIONAL LABORATORY

Oak Ridge, TN 37831-6283

managed by

UT-BATTELLE LLC

for the

US DEPARTMENT OF ENERGY

under contract DE-AC05-00OR22725 



\section{CONTENTS}

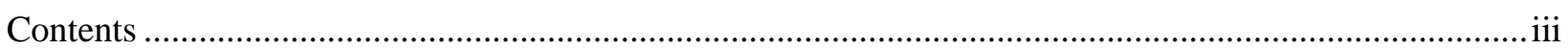

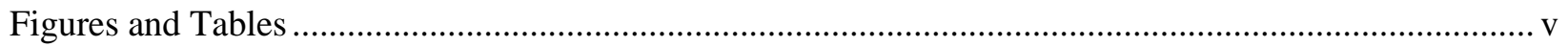

Abbreviations

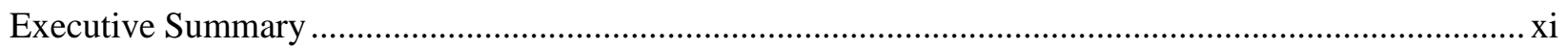

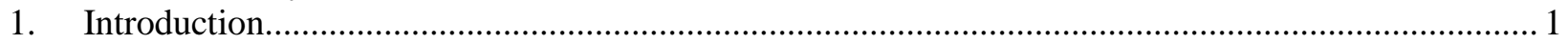

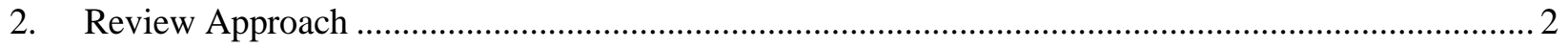

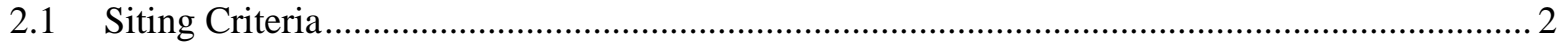

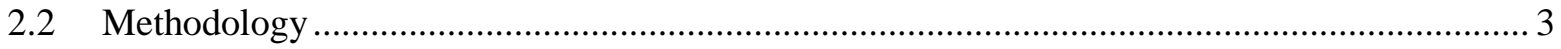

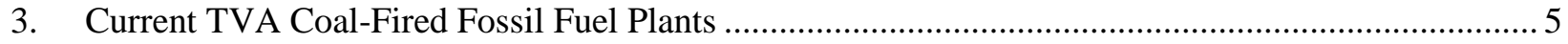

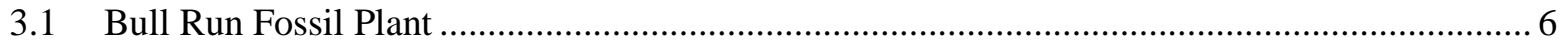

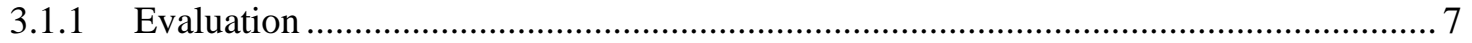

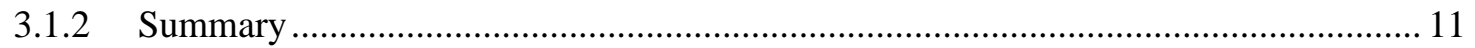

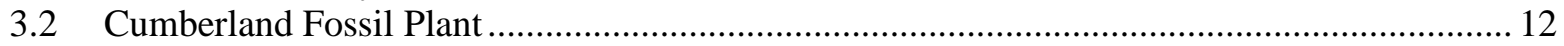

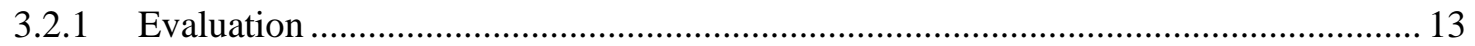

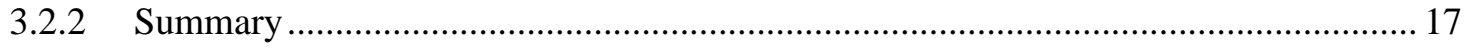

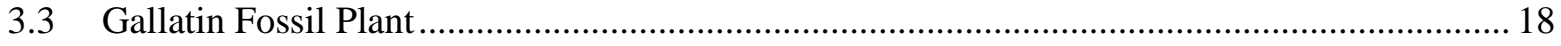

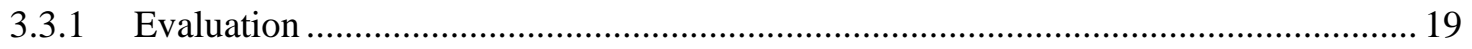

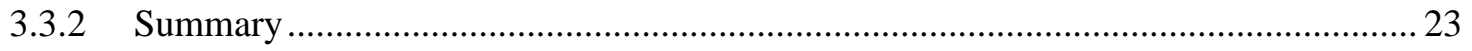

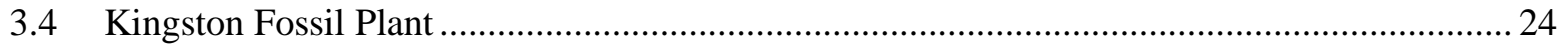

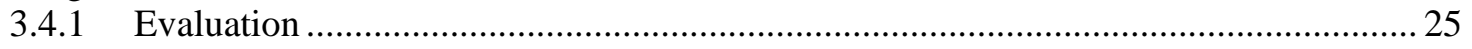

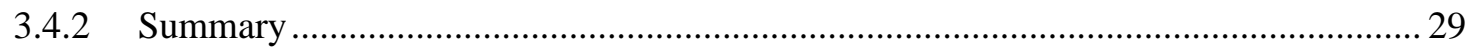

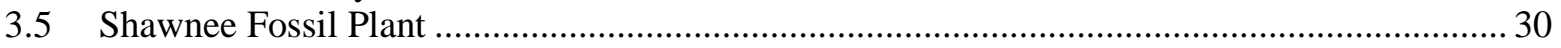

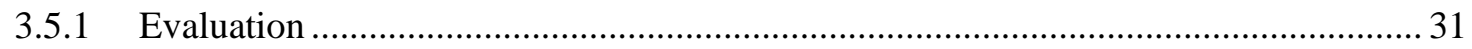

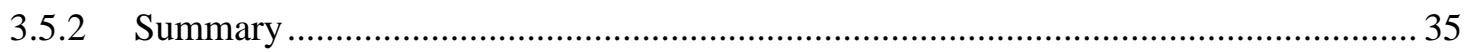

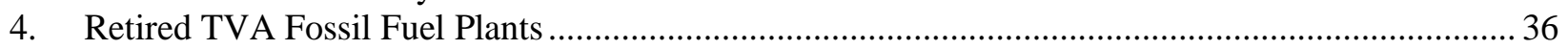

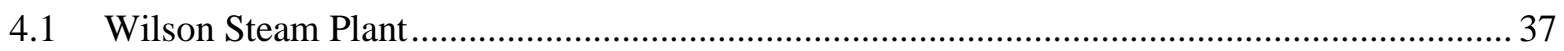

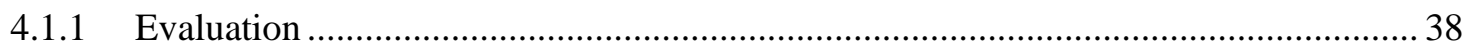

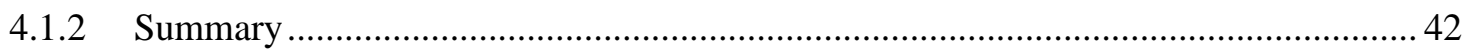

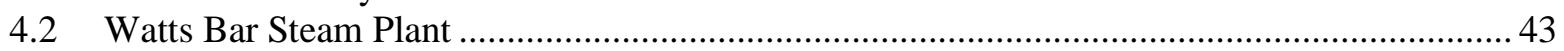

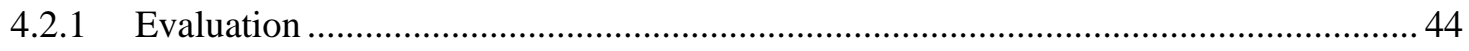

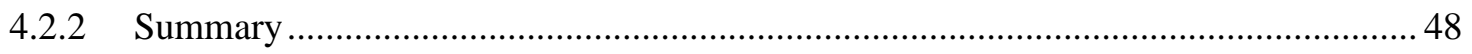

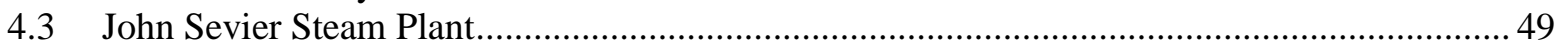

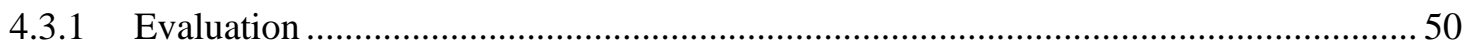

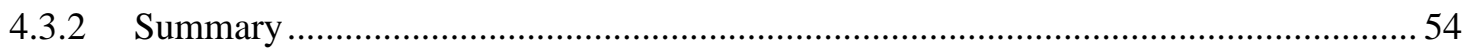

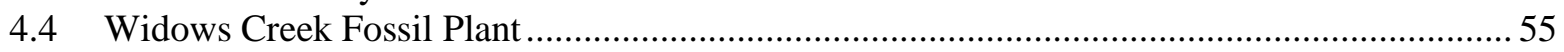

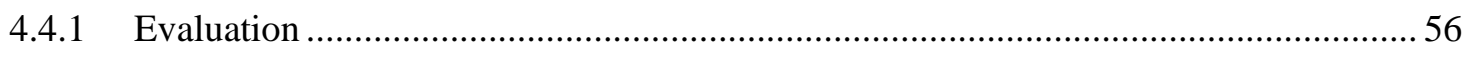

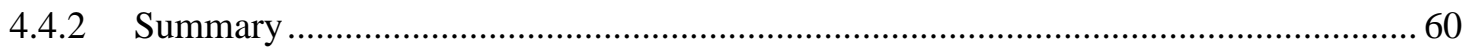

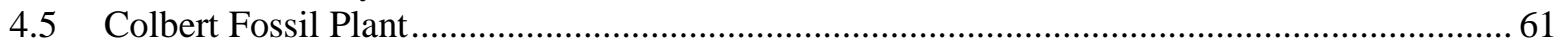

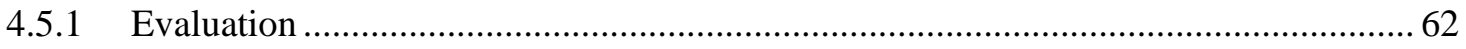

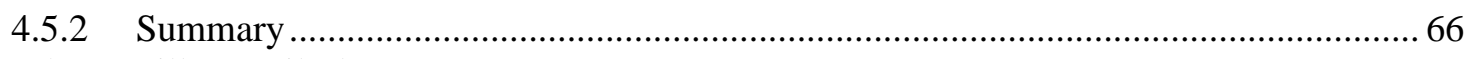

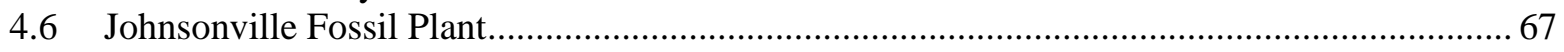

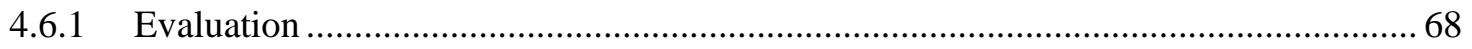

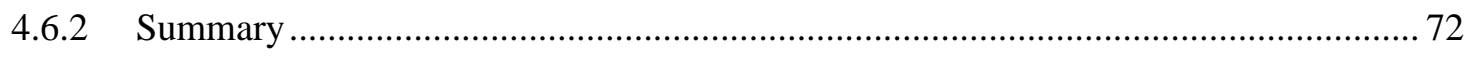

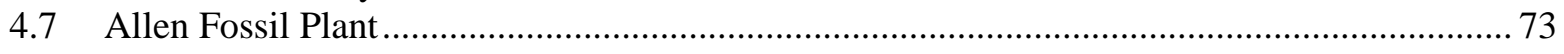

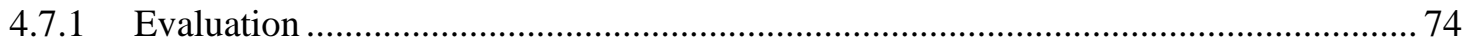

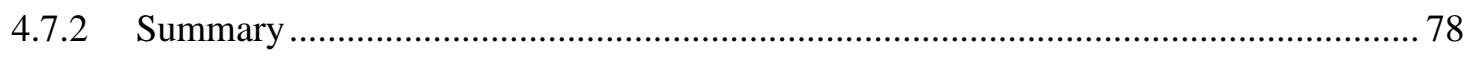

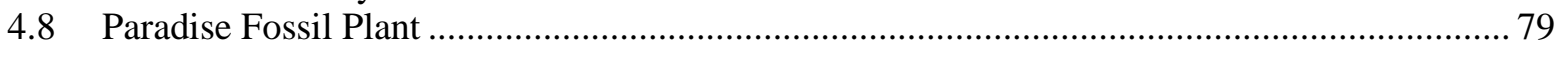

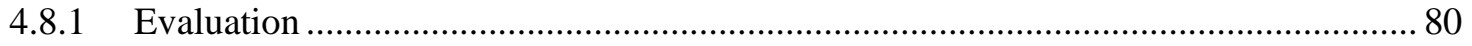


4.8.2 Summary

84

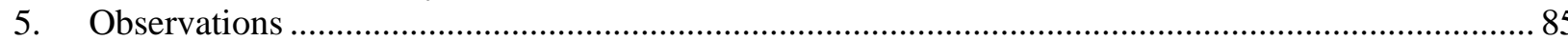

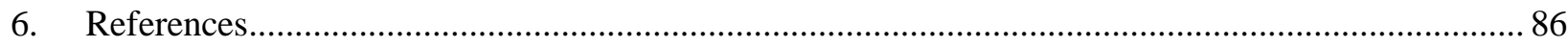

Appendix A. OR-SAGE Algebraic Methodology ……......................................................................... 


\section{FIGURES AND TABLES}

Figure 1. Nominal, bounding SMR composite map detailing siting challenges...................................... 4

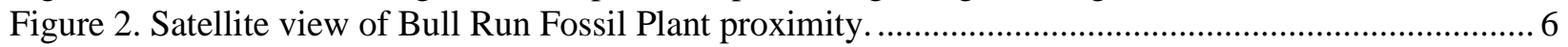

Figure 3. Bull Run Fossil Plant composite map......................................................................... 8

Figure 4. Bull Run Fossil Plant siting criteria maps showing population, wetlands/open water,

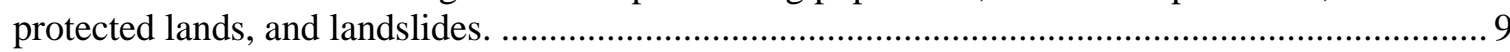

Figure 5. Bull Run Fossil Plant siting criteria maps showing 100-year flood plain, slope,

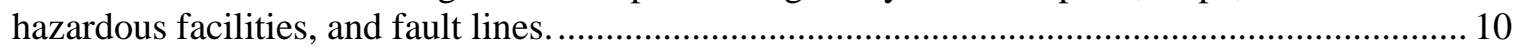

Figure 6. Bull Run Fossil Plant siting criteria maps showing streamflow and SSE............................... 11

Figure 7. Satellite view of Cumberland Fossil Plant proximity .......................................................... 12

Figure 8. Cumberland Fossil Plant composite map. ............................................................................... 14

Figure 9. Cumberland Fossil Plant siting criteria maps showing population, wetlands/open water,

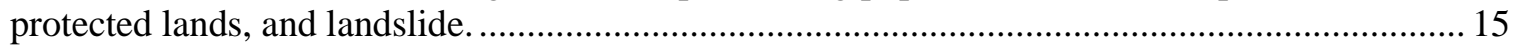

Figure 10. Cumberland Fossil Plant siting criteria maps showing 100-year floodplain, slope,

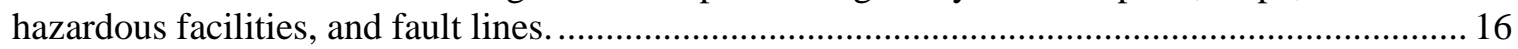

Figure 11. Cumberland Fossil Plant siting criteria maps showing streamflow and SSE ........................ 17

Figure 12. Satellite view of Gallatin Fossil Plant proximity................................................................. 18

Figure 13. Gallatin Fossil Plant composite map. .................................................................................. 20

Figure 14. Gallatin Fossil Plant siting criteria maps showing population, wetlands/open water,

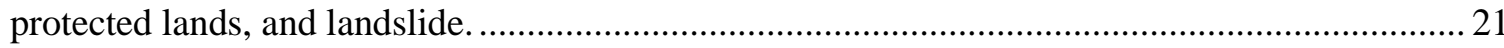

Figure 15. Gallatin Fossil Plant siting criteria maps showing 100-year floodplain, slope,

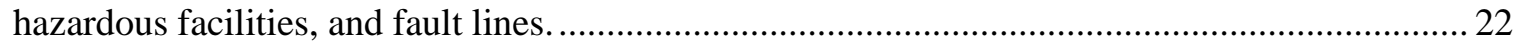

Figure 16. Gallatin Fossil Plant siting criteria maps showing streamflow and SSE .............................. 23

Figure 17. Satellite view of Kingston Fossil Plant proximity .............................................................. 24

Figure 18. Kingston Fossil Plant composite map. .............................................................................. 26

Figure 19. Kingston Fossil Plant siting criteria maps showing population, wetlands/open water,

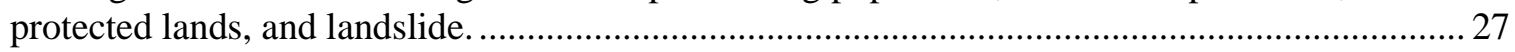

Figure 20. Kingston Fossil Plant siting criteria maps showing 100-year floodplain, slope,

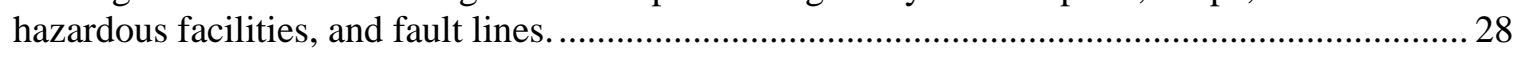

Figure 21. Kingston Fossil Plant siting criteria maps showing streamflow and SSE. ............................29

Figure 22. Satellite view of Shawnee Fossil Plant proximity ............................................................. 30

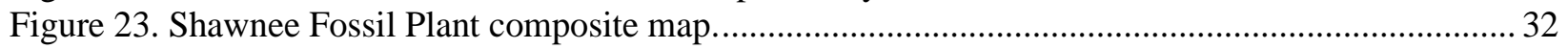

Figure 24. Shawnee Fossil Plant siting criteria maps showing population, wetlands/open water,

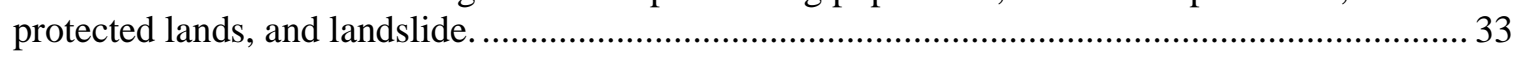

Figure 25. Shawnee Fossil Plant siting criteria maps showing 100-year flood plain, slope,

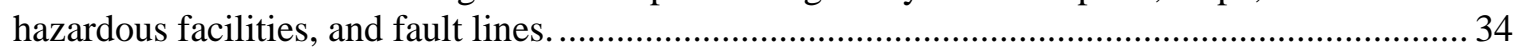

Figure 26. Shawnee Fossil Plant siting criteria maps showing streamflow and SSE. ........................... 35

Figure 27. Satellite view of Wilson Steam Plant proximity................................................................. 37

Figure 28. Wilson Steam Plant composite map. ….............................................................................. 39

Figure 29. Wilson Steam Plant siting criteria maps showing population, wetlands/open water, protected lands, and landslide............................................................................................... 40

Figure 30. Wilson Steam Plant siting criteria maps showing 100-year floodplain, slope,

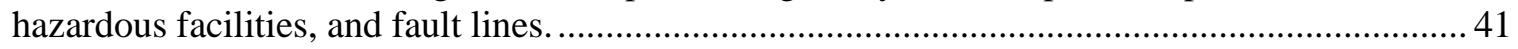

Figure 30. Wilson Steam Plant siting criteria maps showing streamflow and SSE............................... 42

Figure 32. Satellite view of Watts Bar Steam Plant proximity............................................................ 43

Figure 33. Watts Bar Steam Plant composite map................................................................................. 45

Figure 34. Watts Bar Steam Plant siting criteria maps showing population, wetlands/open water, protected lands, and landslide. 
Figure 35. Watts Bar Steam Plant siting criteria maps showing 100-year floodplain, slope, hazardous facilities, and fault lines.

Figure 35. Watts Bar Steam Plant siting criteria maps showing streamflow and SSE. ........................... 48

Figure 37. Satellite view of John Sevier Steam Plant proximity. .............................................................. 49

Figure 38. John Sevier Steam Plant composite map.......................................................................... 51

Figure 39. John Sevier Steam Plant siting criteria maps showing population, wetlands/open water, protected lands, and landslide.

Figure 40. John Sevier Steam Plant siting criteria maps showing 100-year floodplain, slope,

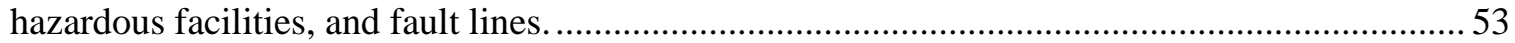

Figure 41. John Sevier Steam Plant siting criteria maps showing streamflow and SSE........................ 54

Figure 42. Satellite view of Widows Creek Fossil Plant proximity.......................................................5

Figure 43. Widows Creek Fossil Plant composite map. ......................................................................5 57

Figure 44. Widows Creek Fossil Plant siting criteria maps showing population, wetlands/open water, protected lands, and landslide ....................................................................................... 58

Figure 45. Widows Creek Fossil Plant siting criteria maps showing 100-year floodplain, slope,

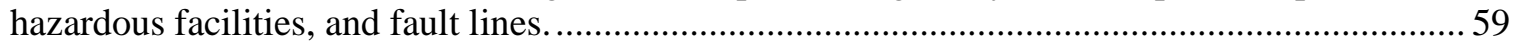

Figure 45. Widows Creek Fossil Plant siting criteria maps showing streamflow and SSE...................... 60

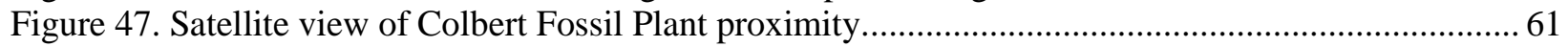

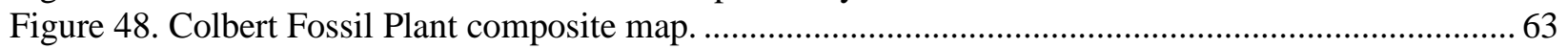

Figure 49. Colbert Fossil Plant siting criteria maps showing population, wetlands/open water,

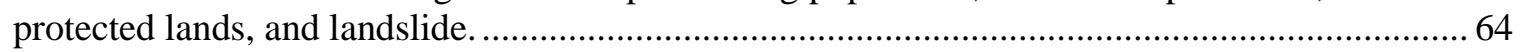

Figure 50. Colbert Fossil Plant siting criteria maps showing 100-year floodplain, slope, hazardous

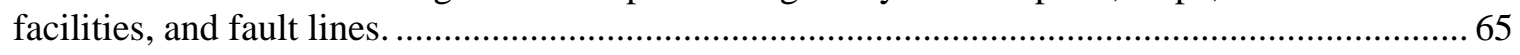

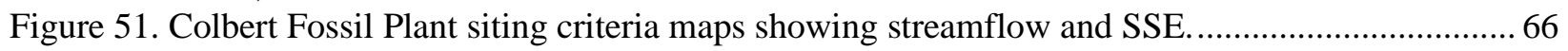

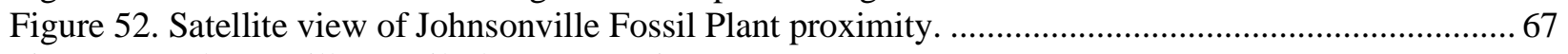

Figure 53. Johnsonville Fossil Plant composite map.......................................................................... 69

Figure 53. Johnsonville Fossil Plant composite maps showing population, wetlands/open water,

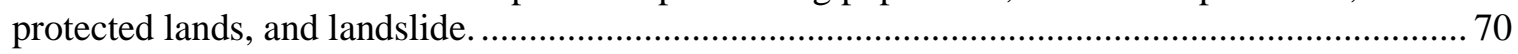

Figure 53. Johnsonville Fossil Plant composite maps showing 100-year floodplain, slope,

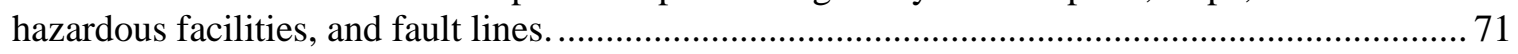

Figure 53. Johnsonville Fossil Plant composite maps showing streamflow and SSE. …....................... 72

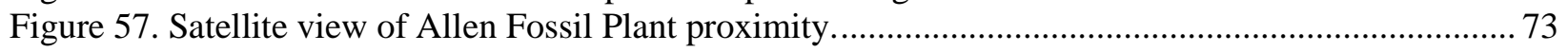

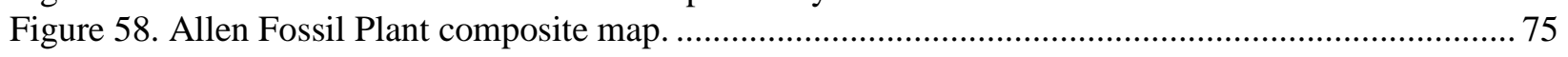

Figure 59. Allen Fossil Plant composite maps showing population, wetlands/open water,

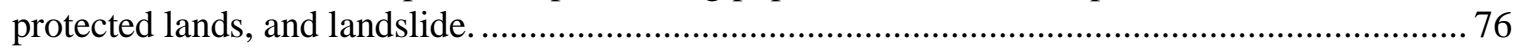

Figure 60. Allen Fossil Plant composite maps showing 100-year floodplain, slope, hazardous

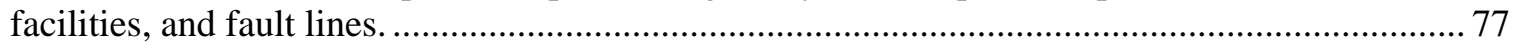

Figure 61. Allen Fossil Plant composite maps showing streamflow and SSE...................................... 78

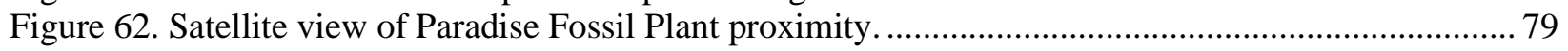

Figure 63. Paradise Fossil Plant composite map................................................................................. 81

Figure 64. Paradise Fossil Plant composite maps showing population, wetlands/open water,

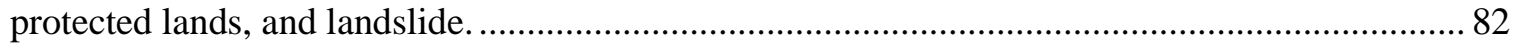

Figure 65. Paradise Fossil Plant composite maps showing 100-year floodplain, slope, hazardous

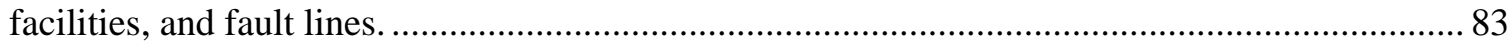

Figure 66. Paradise Fossil Plant composite maps showing streamflow and SSE................................... 84

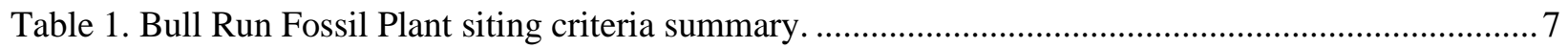

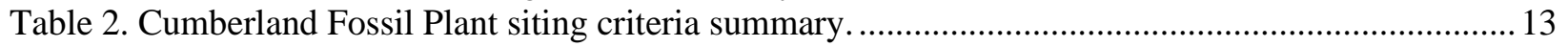

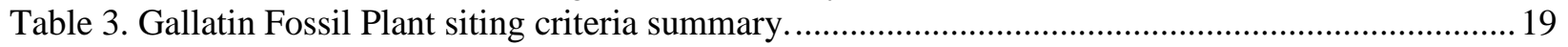

Table 4. Kingston Fossil Plant siting criteria summary......................................................................25 
Table 5. Shawnee Fossil Plant siting criteria summary. .31

Table 6. Wilson Steam Plant siting criteria summary.................................................................... 38

Table 7. Watts Bar Steam Plant siting criteria summary..................................................................... 44

Table 8. John Sevier Steam Plant siting criteria summary ...................................................................50

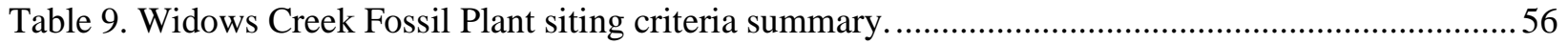

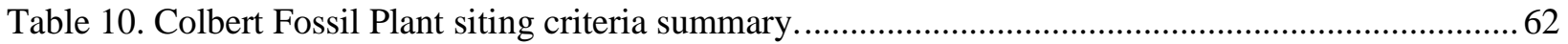

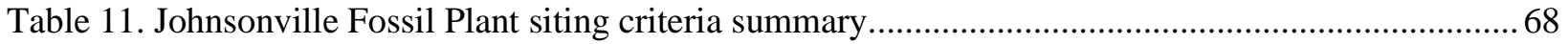

Table 12. Allen Fossil Plant siting criteria summary........................................................................... 74

Table 13. Paradise Fossil Plant siting criteria summary........................................................................ 80 



\section{ABBREVIATIONS}

CFR US Code of Federal Regulations

COVID corona virus disease

DOE US Department of Energy

EIA

US Energy Information Administration

EPRI

Electric Power Research Institute

GIS

geographic information system

IRP integrated resource plan

LWR

light-water reactor

MW

megawatt

NE

Office of Nuclear Energy

Non-LWR

non-light-water reactor

NPP

nuclear power plant

NRC

US Nuclear Regulatory Commission

ORNL

Oak Ridge National Laboratory

OR-SAGE

Oak Ridge Siting Analysis for Power Generation Expansion

PWR

pressurized water reactor

RG

regulatory guide

SA\&I

Systems Analysis and Integration [Campaign]

SMR

small modular reactor

SSE

safe shutdown earthquake

SSEC

site selection evaluation criteria

TVA

Tennessee Valley Authority

USGS

US Geological Survey 



\section{EXECUTIVE SUMMARY}

Various internal stakeholders at Oak Ridge National Laboratory (ORNL) have been addressing key questions related to our national electrical energy supply. Several years ago, this effort led to the development of a tool, the Oak Ridge Siting Analysis for Power Generation Expansion (OR-SAGE), to support power plant siting evaluations. The geographic information system (GIS)-based tool uses industry-accepted approaches to establish appropriate criteria for screening sites based on data sources available at ORNL.

OR-SAGE is essentially a dynamic visualization database that has matured under the US Department of Energy (DOE) Office of Nuclear Energy (NE) Systems Analysis and Integration (SA\&I) Campaign to enable additional functionality, including application to fuel cycle facilities, advanced fuel cycle deployment scenarios, and transportation considerations. The Tennessee Valley Authority (TVA) is the regional electricity supplier to ORNL and is an immediate neighbor, with its corporate headquarters in nearby Knoxville, Tennessee.

This report summarizes the application of the OR-SAGE tool to the potential backfit of a small modular reactor (SMR) or an advanced non-light-water reactor (non-LWR) at a current or former TVA coal plant site to serve as an example in support of the DOE-NE SA\&I Campaign. The OR-SAGE development funded by this campaign has led to additional development and application of the tool.

TVA was created as a public company in 1933 by the TVA Act for flood control, navigation, and electrification of the Tennessee Valley. The most recent TVA integrated resource plan (IRP) specifies how the utility is planning for new technology, aging infrastructure, integration of distributed energy sources, integration of renewable and clean energy sources, energy efficiency, and evolving environmental regulations. OR-SAGE provides information to be used for near- and long-term planning for generation and distribution of electricity to meet anticipated demand for TVA or other utilities. Many utility IRPs indicate a move away from coal-fired electricity generation and a move toward cleaner technology [1,2]. Some utilities are proposing to retire all coal-fired electricity generation in the next 15 years [3]. The most recent TVA IRP indicates that TVA is open to evaluating emerging nuclear technologies, including SMRs, as part of its technology innovation efforts.

There are 13 current and former coal-fired plant sites in the TVA service territory, including sites in Alabama, Kentucky, and Tennessee. This report presents evaluations of these sites using the OR-SAGE siting analysis tool. Along with the banked Clinch River site, most of the current and former TVA coal plant sites are suitable for SMR or advanced non-LWR technology siting based on an OR-SAGE site review. Many sites have alternative energy source uses, including hydroelectric, gas, and nuclear, to be considered for energy planning. Therefore, any future decision to add nuclear SMR or advanced nonLWR capacity will depend on technology economics and regional demand. Furthermore, current interest in electrifying transportation in the region could be a significant factor in any future decision. 



\section{INTRODUCTION}

The Tennessee Valley Authority (TVA) was created as a public company in 1933 by the TVA Act for flood control, navigation, and electrification of the Tennessee Valley. Like most utilities, TVA periodically files an integrated resource plan (IRP) detailing plans for new technology, aging infrastructure, integration of distributed energy sources, integration of renewable and clean energy sources, energy efficiency, and evolving environmental regulations. IRPs inform rate payers, investors, politicians, policy makers, environmentalists, and others about the near- and long-term planning for generation and distribution of electricity to meet anticipated demand. Many current utility IRPs indicate a move away from coal-fired electricity generation toward cleaner technology [1,2]. Some utilities are proposing to retire all coal-fired electricity generation in the next 15 years [3]. In its 2019 IRP [4], TVA noted that it will continue with announced plans to retire the Paradise Fossil Plant in 2020 and the Bull Run Fossil Plant in 2023. TVA will further evaluate retirements of up to 2,200 MW of additional coal capacity over the next 10-20 years if it proves to be cost effective. The 2019 TVA IRP also indicates that TVA will pursue license renewal options for its existing nuclear fleet while evaluating emerging nuclear technologies, including small modular reactors (SMRs) as part of technology innovation efforts.

Based on population growth in the TVA service area and growing electrical demand, the TVA IRP estimated that TVA will add up to $500 \mathrm{MW}$ in demand response by 2038, depending on resource availability and cost. This pre-corona virus disease (COVID) pandemic estimate is now subject to a downward change. The US Department of Energy (DOE) Energy Information Administration (EIA) projects that total US energy consumption will return to 2019 levels between 2029 and 2050, depending on the pace of post-COVID economic recovery [4]. Tennessee strongly supports electrification of the transportation sector, which could significantly increase the region's demand for energy at a rate faster than the demand anticipated from the overall economy.

The 2019 TVA IRP and current conditions indicate that there is an opportunity to implement additional nuclear resources in the TVA region in the form of SMRs and advanced non-light-water reactors (nonLWRs). There is bipartisan support for nuclear energy to be part of the new clean energy supply in the form of SMRs and advanced non-LWRs. Retirement of numerous TVA fossil plant assets provides a government-supported siting opportunity for SMRs and non-LWRs that should be explored. Oak Ridge National Laboratory (ORNL) has developed a geographic information system (GIS)-based tool [5,6], Oak Ridge Siting Analysis for power Generation Expansion (OR-SAGE), to provide an overview of TVA's fossil plant assets. OR-SAGE is used to inform owners, vendors, policymakers, regulators, and other stakeholders on nuclear fuel cycle siting issues, site availability, capacity availability, fuel cycle optimization, transport optimization, coal-fired plant backfits, and other matters.

OR-SAGE is essentially a dynamic visualization database that has evolved under the DOE Office of Nuclear Energy (NE) Systems Analysis and Integration (SA\&I) Campaign to enable additional functionality, including application to fuel cycle facilities, advanced fuel cycle deployment scenarios, and transportation considerations. TVA is the regional electricity supplier to ORNL and is an immediate neighbor with its corporate headquarters in nearby Knoxville, Tennessee. This report summarizes application of the OR-SAGE tool to the potential backfit of an SMR or an advanced non-LWR at a current or former TVA coal plant site to serve as an example in support of the DOE-NE SA\&I Campaign. OR-SAGE provides information to be used in the near- and long-term planning for generation and distribution of electricity to meet the anticipated demand for TVA or other utilities. 


\section{REVIEW APPROACH}

There are 13 current and former coal-fired plant sites in the TVA service territory, including sites in Alabama, Kentucky, and Tennessee, and OR-SAGE will be used to evaluate these sites. OR-SAGE provides a flexible system to (1) evaluate power plant siting options and considerations for a variety of power sources, and (2) identify nuclear waste storage siting options. OR-SAGE provides insights on siting issues such as suitable locations, regional capacity, and population density $[5,6]$.

\subsection{SITING CRITERIA}

Power reactor siting in the United States is based on limiting dose to individuals on the site exclusion area boundary and on the boundary of a low-population zone as defined in Title 10 to the Code of Federal Regulations, Part 100 (10 CFR 100). There is also well-defined regulatory guidance [7] for siting a nuclear power plant (NPP) in the US in US Nuclear Regulatory Commission (NRC) Regulatory Guide 4.7 (RG 4.7), "General Site Suitability Criteria for Nuclear Power Stations.” Furthermore, the Electric Power Research Institute (EPRI) siting guide [8] for NPPs, which is based on obtaining an early site permit, is updated periodically. Approximately 50 potential site selection evaluation criteria (SSEC) are identified in the various sources related to public health and safety, environment, socioeconomic, and engineering factors. The selected SMR siting factors for a nominal small NPP provide a high level of discrimination and readily available data. The default SMR siting criteria are as follows:

- Land with a population density greater than 500 people per square mile (including a

4-mile buffer) is excluded. The cap at 4 miles is based on vendors demonstrating small source terms that meet the 10 CFR 100 dose requirements at or near the NPP exclusion area boundary. Otherwise, the cap per RG 4.7 guidance is set at 20 miles for large LWRs.

- Wetlands and open water are excluded.

- Protected lands (e.g., national parks, historic areas, wildlife refuges) are excluded.

- Land with a moderate or high landslide hazard susceptibility is excluded. This is a flag based on broad-based risk assessments by the US Geological Survey (USGS) and is not a substitute for indepth geological evaluations at the site.

- Land that lies within a 100-year floodplain is excluded.

- Land with a slope greater than $18 \%\left(\sim 10^{\circ}\right)$ is excluded. This is an economic consideration regarding site preparation.

- Land areas that are more than 20 miles from cooling water makeup sources with at least 65,000 gallons per minute are excluded for nominal SMR plant applications. Advanced non-LWRs may not need this resource, but this requirement provides a complete bounding analysis for the coal-fired plants being evaluated.

- Land too close to the identified fault lines is excluded; the length of the fault line determines the required standoff distance per 10 CFR 100, Appendix A.

- Land located in proximity to hazardous facilities (airports, military facilities, missile generating or toxic gas generating facilities) is avoided. This is a flag based on a broad consideration for risk and RG 4.7 guidance. Meeting this avoidance criterion is not a substitute for an in-depth risk assessment. 
- Land with safe shutdown earthquake (SSE) peak ground acceleration (2\% chance in a 50-year return period) greater than $0.5 \mathrm{~g}$ is excluded. This can be adjusted based on individual technology design specifications.

The algebraic approach employed in OR-SAGE is summarized in Appendix A. Based on preliminary design information and expert judgment, it is assumed that an SMR, as defined by multiple vendors, can easily be accommodated on a 50-acre footprint. Many proposed advanced reactor NPP technologies have even smaller proposed footprints. Microreactors may require a footprint of only a few acres.

\subsection{METHODOLOGY}

While OR-SAGE does not replace the required detailed evaluation of candidate NPP sites, the tool is designed to use industry-accepted practices [8] to screen regions and sites for NPP siting opportunities. The tool employs an array of data sources through ORNL's considerable GIS computational capabilities. The screening process divides the contiguous United States into $100 \times 100 \mathrm{~m}$ (1-hectare or $~ 2.5$-acre) squares (cells), applying the successive exclusionary, avoidance, and suitability parameters listed above from over 50 datasets to each of the 700 million individual land cells in the database. Appropriate layered selection queries are generated as associated with each siting criterion, including application of recommended buffer zones. The result of any given set of query values is a static visual output reflecting the relational values stored in the database.

Because OR-SAGE tracks the query parameters for each $100 \times 100 \mathrm{~m}$ cell, the output can be used not only to visually identify the cells clear of all the SSEC layer exclusions, but it can also identify cells that are tripped by one, two, or three or more exclusions. The result is known as the SMR composite map. A sample SMR national composite map is shown in Figure 1. A similar map can be prepared for the detailed area around a site of interest. The composite feature is a powerful feature, because it allows areas with a limited number of siting challenges to also be identified. Engineering solutions may be available for areas with limited siting challenges. 


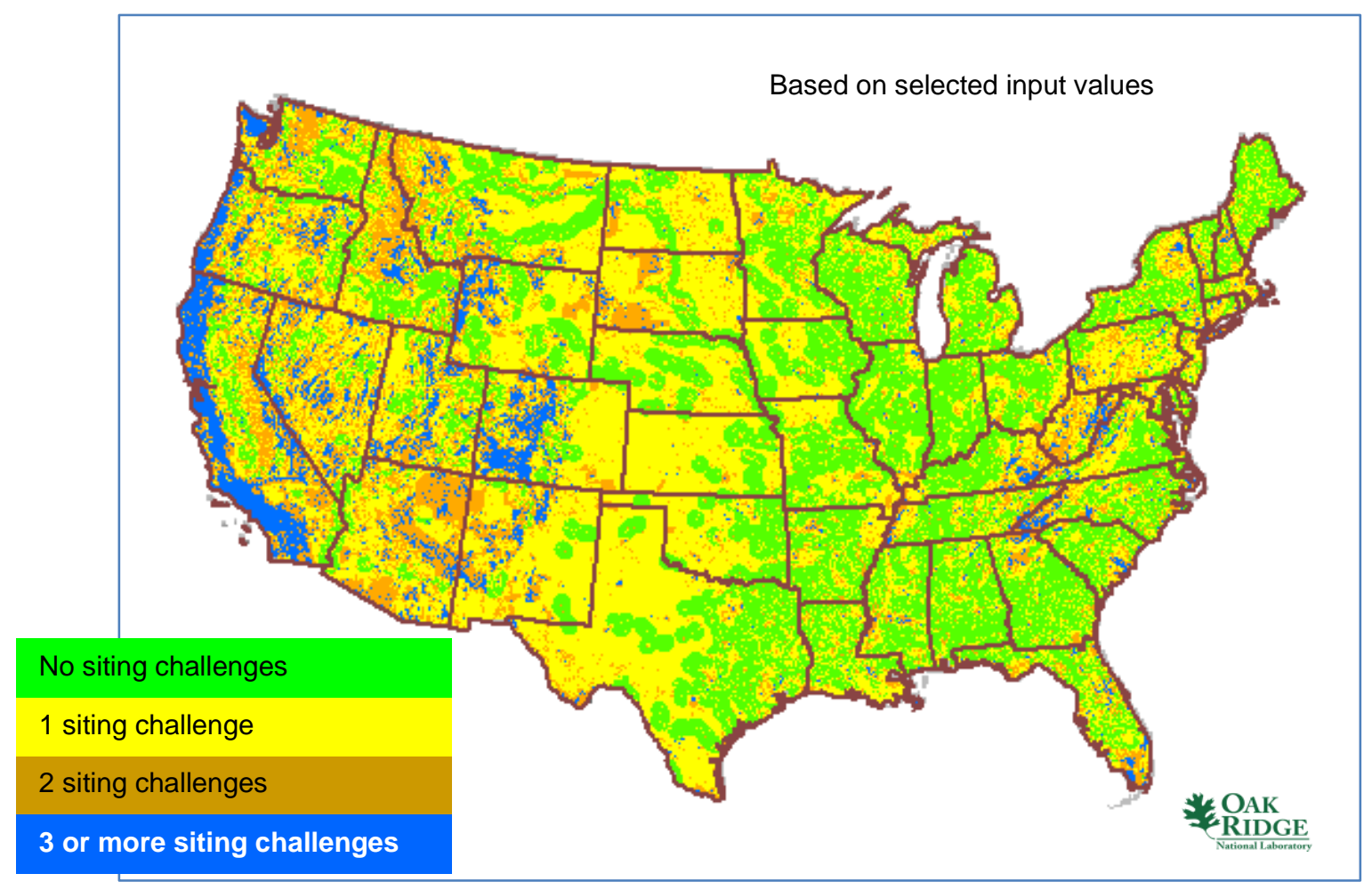

Figure 1. Nominal, bounding SMR composite map detailing siting challenges.

As was done for a previous siting study on a selected group of coal-fired plants [9], a siting analysis summary was performed for each of the 13 current and former coal-fired plant sites in the TVA service territory. In each coal-fired plant summary, a satellite aerial view of the plant with overlaid concentric circles at 0.5 -mile and 1-mile radii provides a convenient look at the area's topography, including major nearby roads, rivers, and population activity such as towns and subdivisions.

Following the satellite view of each TVA coal-fired plant, a screening criteria summary bar or dashboard chart for the 0.5- and 1.0-mile circles provides a quick look at the SMR siting issues for the site. (See Table 1 for an example.) The SMR siting parameters that are not met within each of the 0.5- and 1.0-mile circles are indicated. If an SMR siting parameter box is green, then there is no potential siting issue. Hatched purple and green indicates that only a portion of the area does not meet that parameter and is termed a partial siting issue for some part of one of the circles. A solid purple box indicates that the particular SMR parameter is an issue requiring further evaluation for the entire site at one or both of the 0.5- and 1.0-mile radius circles. The SMR parameters are listed, along with their respective values, below the summary bar for reference.

In each evaluation summary, the coal station screening criteria dashboard is followed by a localized composite map similar to the national composite map shown in Figure 1. At this scale, individual $100 \times 100$ m cells can be identified. The cells are color coded, as shown in Figure 1, to show compounded SMR unmet siting criteria at a glance.

After the coal station composite map, ten smaller individual siting criterion maps are included to indicate the locations where the selected individual parameter values may not be met within the 0.5- and 1.0-mile radius circles. Any areas shown in a magenta color do not meet the individual siting criterion at the value selected for SMR screening. 
The current TVA coal-fired fossil fuel plants are evaluated in Section 3. The retired TVA coal-fired fossil fuel plants are evaluated in Section 4. Some of the plants evaluated in Section 4 have been retired for an extended period of time, so their former plant infrastructures have been removed. In some cases, the land has been repurposed. This may diminish the advantage and potential for siting an SMR at one of these sites. However, all 13 current and former TVA coal plant sites have been evaluated. A summary is provided in Section 5.

\section{CURRENT TVA COAL-FIRED FOSSIL FUEL PLANTS}

Since its inception, TVA has operated 13 coal-fired power plants/stations. At its peak in 1985, TVA's coal fleet included 12 stations, five of which are still active - four in Tennessee, and 1 in Kentucky:

- Bull Run Fossil Plant

- Cumberland Fossil Plant

- Gallatin Fossil Plant

- Kingston Fossil Plant

- Shawnee Fossil Plant

There is a total of 25 generating units at these five power stations [10,11].

TVA plans to retire all of its active coal plants no later than 2035. Replacement power will likely lean toward the use of gas plants because of their flexibility in responding to demand variability [4]. 


\subsection{BULL RUN FOSSIL PLANT}

The Bull Run Fossil Plant is located on 750 acres on the north bank of Bull Run Creek and across the Clinch River from Oak Ridge, Tennessee. It is the only single-unit coal-fired power station in the TVA system. Construction started in 1962, and when the generator went into operation in 1967, it produced the largest volume of steam in the world. The plant has a summer net capability of 865 megawatts [10]. Aerial imagery of the plant's topography is shown in Figure 2, with areas swept by a half-mile circle and a 1-mile circle, as discussed in Section 2.2. State Road 170 runs by the front of the plant.

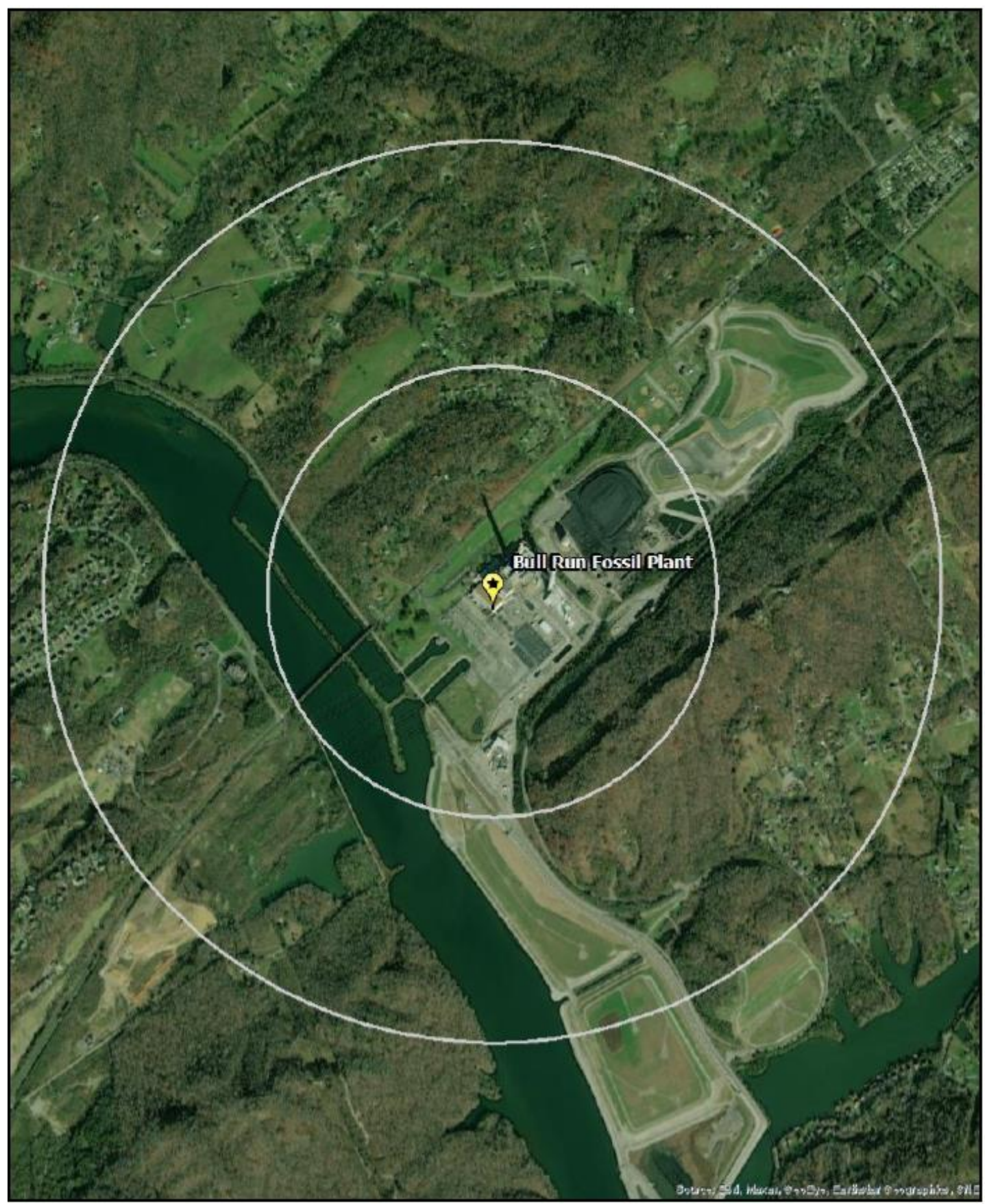

Figure 2. Satellite view of Bull Run Fossil Plant proximity. 


\subsubsection{Evaluation}

The screening results for the Bull Run site are listed in Table 1, and a composite map for the surrounding area is shown in Figure 3. The physical plant structures are located on land, with one siting issue. Maps of the individual SMR siting criteria based on selected input values are also provided below.

Table 1. Bull Run Fossil Plant siting criteria summary

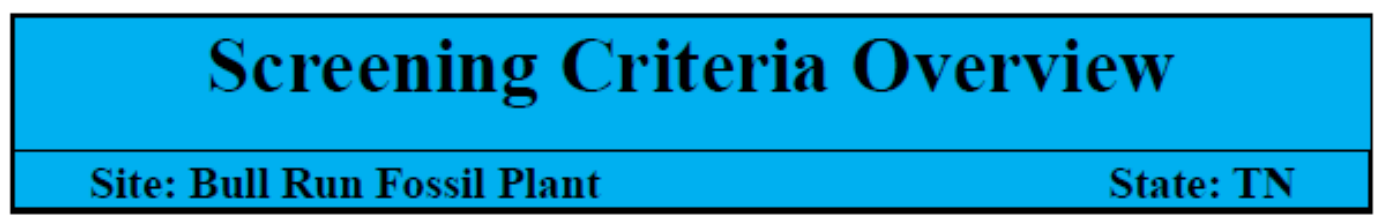

\begin{tabular}{|c|c|c|c|c|c|c|c|c|c|c|}
\hline \multicolumn{11}{|c|}{ Screening Criteria Summary Bar } \\
\hline \multicolumn{3}{|c|}{ No Siting Issue } & \multicolumn{4}{|c|}{ Partial Siting Issue } & & \multicolumn{3}{|c|}{ Full Siting Issue } \\
\hline $\begin{array}{c}\text { Inside } \\
\text { the } 0.5 \\
\text { mile } \\
\text { Radius }\end{array}$ & \begin{tabular}{c|} 
Pop \\
Density
\end{tabular} & $\begin{array}{l}\text { Wet- } \\
\text { lands }\end{array}$ & \begin{tabular}{|c|} 
Protected \\
Lands
\end{tabular} & Landslide & \begin{tabular}{c|}
$100-\mathrm{yr}$ \\
Flood- \\
plain
\end{tabular} & \begin{tabular}{|l|} 
Slope \\
$(18 \%)$
\end{tabular} & \begin{tabular}{|c|} 
Hazardous \\
Facilities
\end{tabular} & $\begin{array}{l}\text { Fault } \\
\text { Lines }\end{array}$ & $\begin{array}{c}\text { Stream- } \\
\text { flow } \\
\text { (30K } \\
\text { GPM) }\end{array}$ & $\begin{array}{c}\text { SSE } \\
(0.5 \mathrm{~g})\end{array}$ \\
\hline $\begin{array}{l}\text { Inside } \\
\text { the } \\
0.6 \text { to } 1- \\
\text { mile } \\
\text { Radius }\end{array}$ & $\begin{array}{c}\text { Pop } \\
\text { Density }\end{array}$ & $\begin{array}{l}\text { Wet- } \\
\text { lands }\end{array}$ & \begin{tabular}{|c|} 
Protected \\
Lands
\end{tabular} & Landslide & \begin{tabular}{c|}
$100-\mathrm{yr}$ \\
Flood- \\
plain
\end{tabular} & \begin{tabular}{|l|} 
Slope \\
$(18 \%)$
\end{tabular} & \begin{tabular}{|c|} 
Hazardous \\
Facilities
\end{tabular} & $\begin{array}{l}\text { Fault } \\
\text { Lines }\end{array}$ & \begin{tabular}{c|} 
Stream- \\
flow \\
(30K \\
GPM)
\end{tabular} & $\begin{array}{c}\mathrm{SSE} \\
(0.5 \mathrm{~g})\end{array}$ \\
\hline \multicolumn{11}{|c|}{ Screening Criteria Table } \\
\hline \multicolumn{7}{|c|}{ Criteria } & \multicolumn{4}{|c|}{ Value } \\
\hline \multicolumn{7}{|c|}{ Population Density within 4 miles } & \multicolumn{4}{|c|}{$>500$ (people/square mile) } \\
\hline \multicolumn{7}{|c|}{ Wetlands and Open water are excluded } & \multicolumn{4}{|c|}{-} \\
\hline \multicolumn{7}{|c|}{ Protected lands are excluded } & \multicolumn{4}{|c|}{-} \\
\hline \multicolumn{7}{|c|}{ Land with moderate/high landslide hazard susceptibility are excluded } & \multicolumn{4}{|c|}{-} \\
\hline \multicolumn{7}{|c|}{ Land that lies within a 100 -year floodplain is excluded } & \multicolumn{4}{|c|}{ - } \\
\hline \multicolumn{7}{|l|}{ Slope } & \multicolumn{4}{|c|}{$>18 \%\left(\sim 10^{\circ}\right)$} \\
\hline \multicolumn{7}{|c|}{$\begin{array}{l}\text { Land located in proximity to hazardous facilities } \\
\text { (Airport - 5mi; Oil Refineries - } 1 \mathrm{mi} \text {; and Military Bases }-1 \mathrm{mi} \text { ) }\end{array}$} & \multicolumn{4}{|c|}{-} \\
\hline \multicolumn{7}{|c|}{ Land too close to identified fault lines is avoided } & \multicolumn{4}{|c|}{-} \\
\hline \multicolumn{7}{|c|}{ Streamflow within 20 miles } & \multicolumn{4}{|c|}{$\geq 30,000 \mathrm{gpm}$} \\
\hline \multicolumn{7}{|c|}{ Safe-shutdown earthquake peak ground acceleration } & \multicolumn{4}{|c|}{$\geq 0.5 \mathrm{~g}$} \\
\hline
\end{tabular}




\section{Site Characterization: Composite Map}

Site: Bull Run Fossil Plant

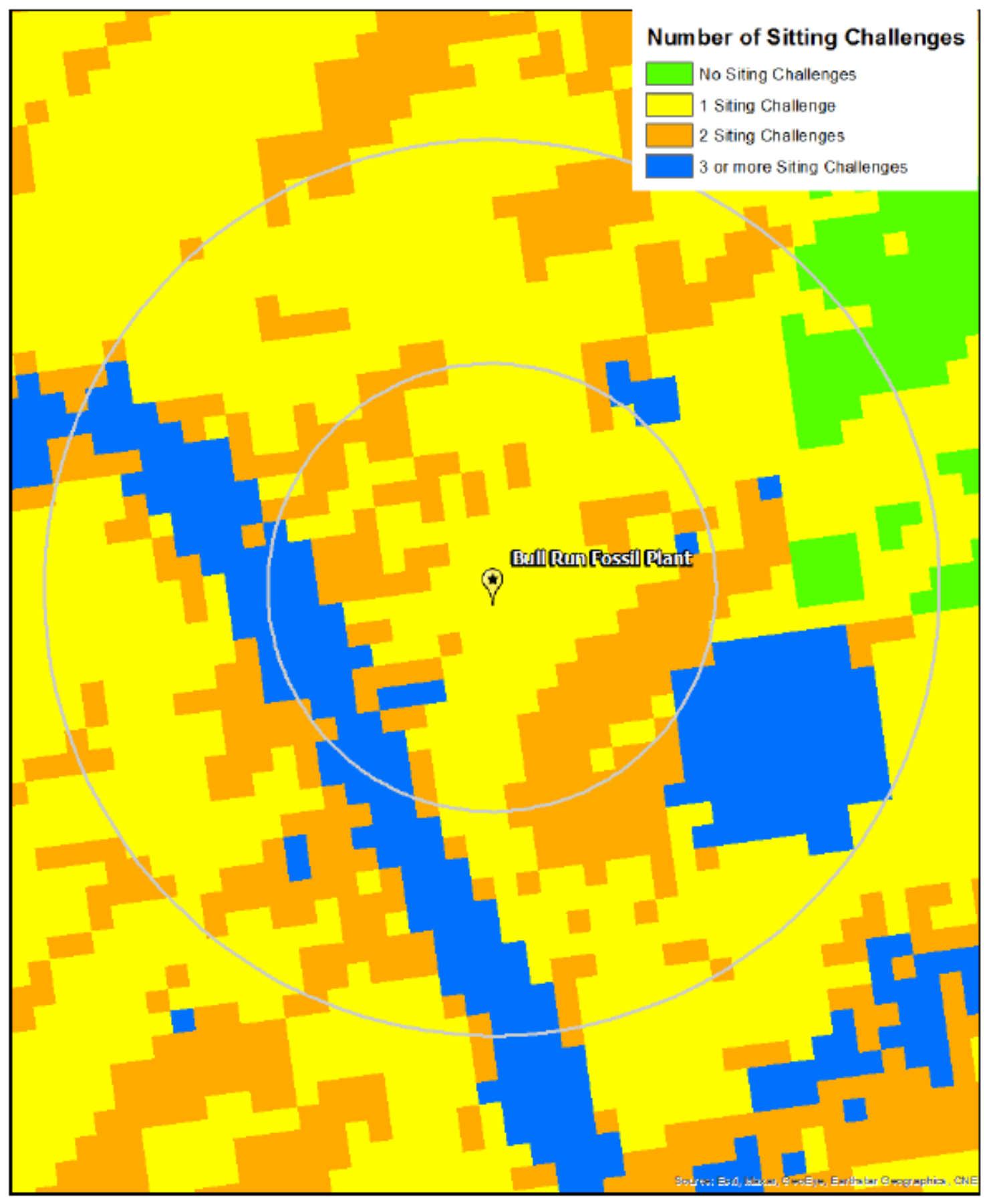

Figure 3. Bull Run Fossil Plant composite map. 

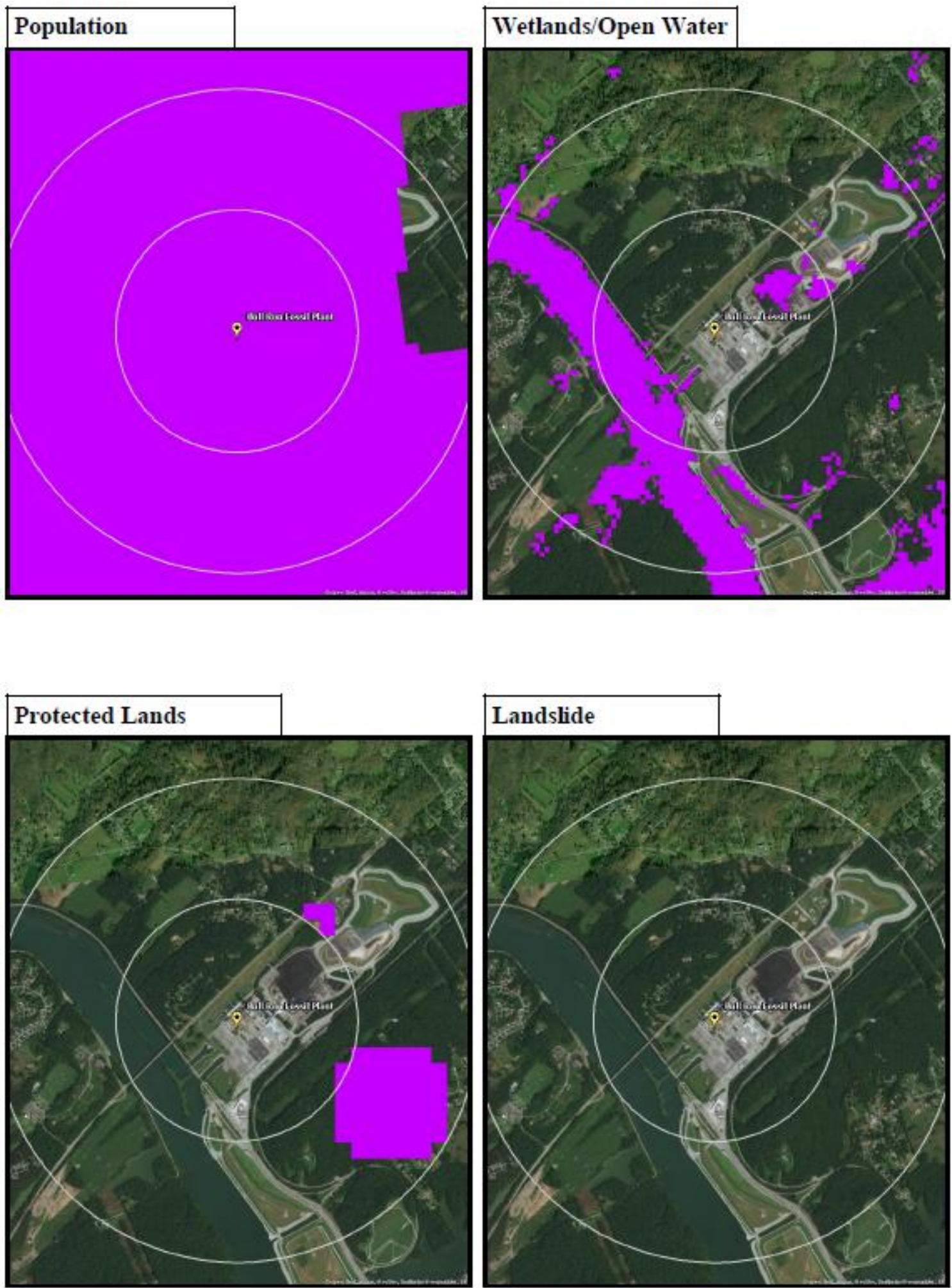

Figure 4. Bull Run Fossil Plant siting criteria maps showing population, wetlands/open water, protected lands, and landslides. 

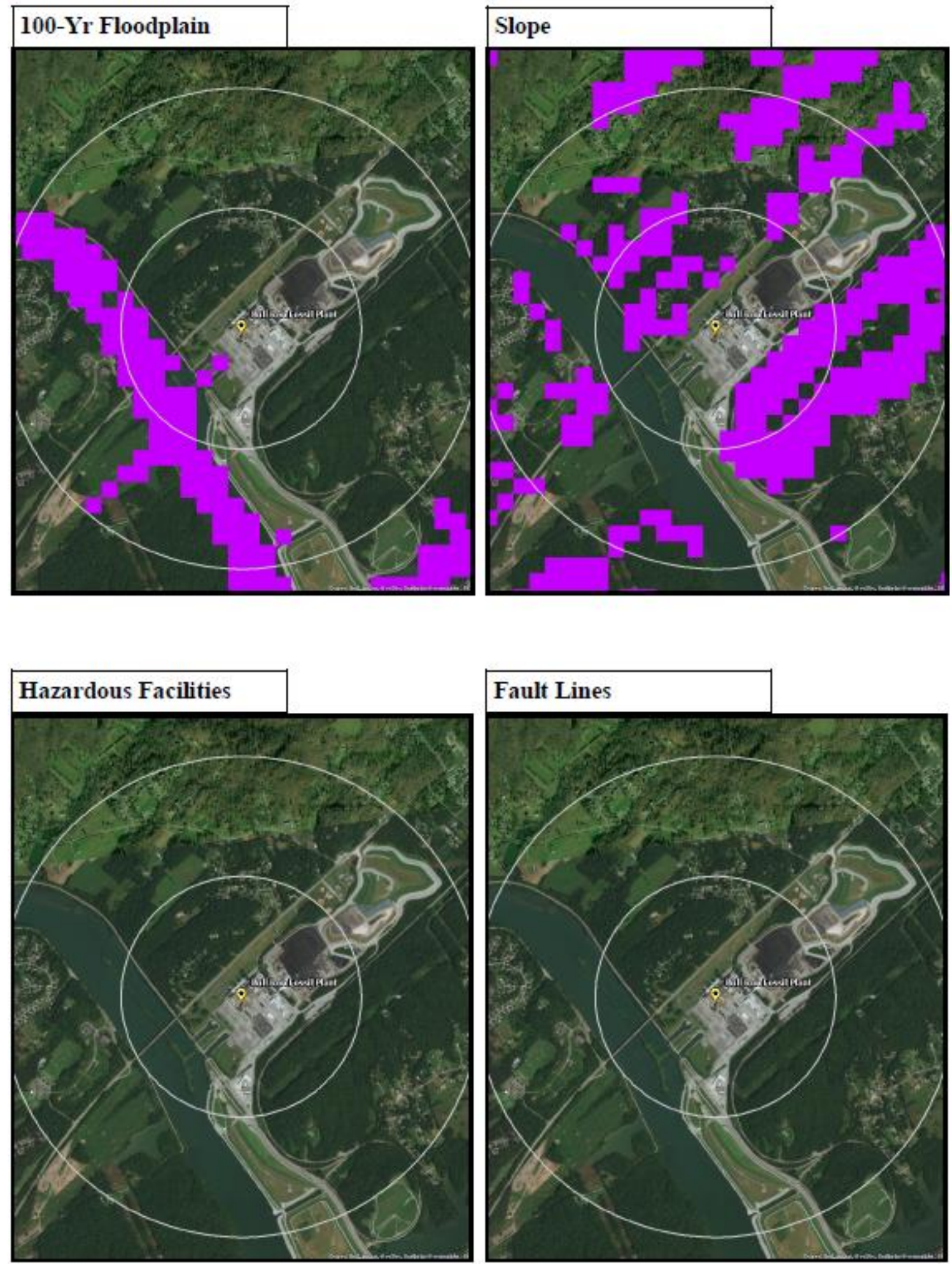

Figure 5. Bull Run Fossil Plant siting criteria maps showing 100-year flood plain, slope, hazardous facilities, and fault lines. 

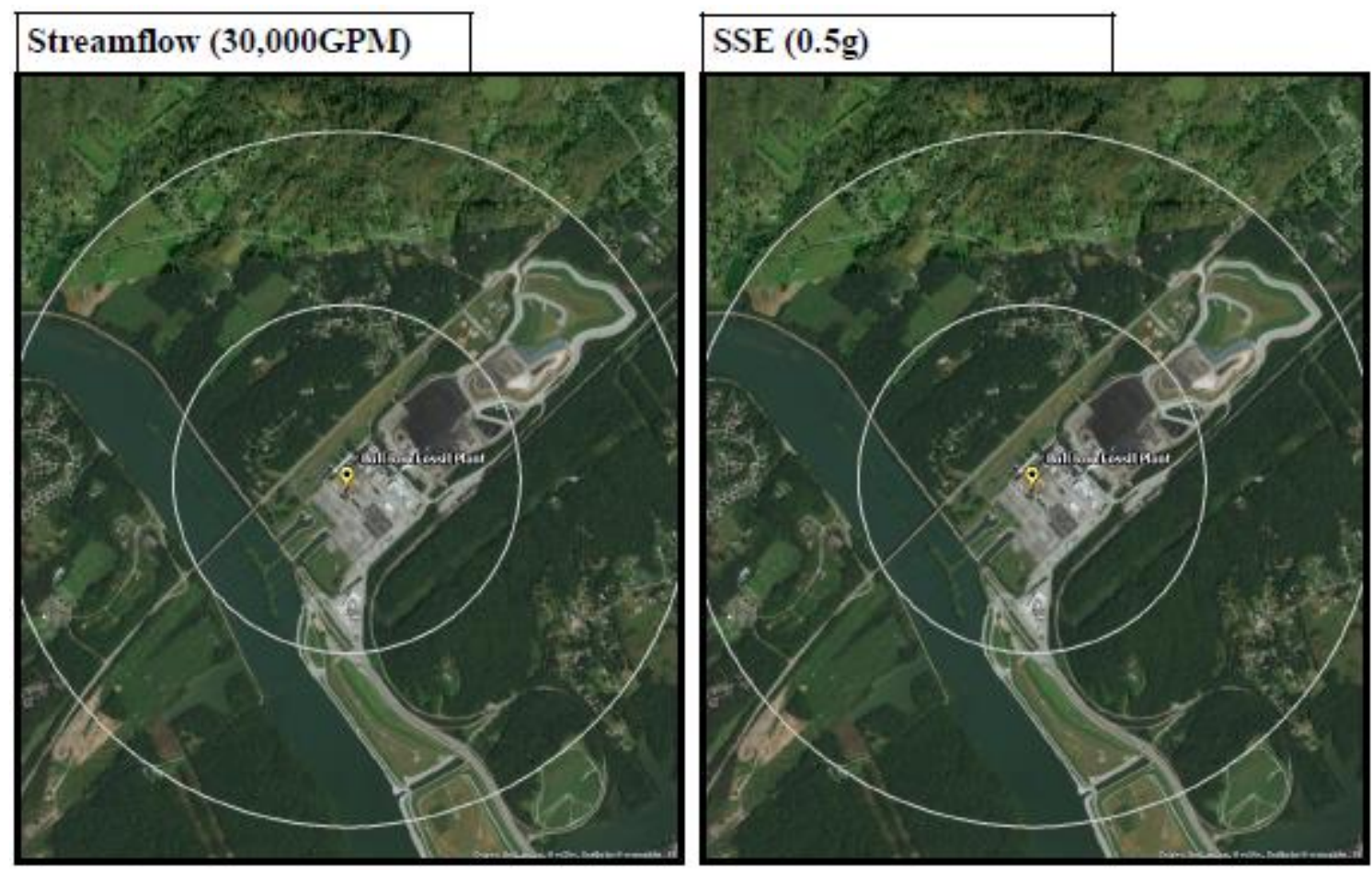

Figure 6. Bull Run Fossil Plant siting criteria maps showing streamflow and SSE.

\subsubsection{Summary}

After a detailed review of fuel, transmission, economic and environmental impacts, as well as reviewing public input, on February 14, 2019, the TVA Board of Directors approved the retirement of Bull Run Fossil Plant by December 2023 [10].

Because of the site's proximity to Oak Ridge, Tennessee and the Solway community, population density is a significant issue for the Bull Run site except for a small area to the northeast of the generator. This accounts for the dominate yellow coloring in Figure 3. Population density restriction calculations were capped at 4 miles. Depending on the nuclear technology selected, closed siting with respect to population density may be possible. This would open some additional area for consideration.

Open water, slope, and floodplain also cross the site, posing issues associated with a plant located on a body of water. In addition, a church to the southeast of the generator and another church to the north of the generator provide some protected land to be considered for SMR siting.

The Bull Run site contains sufficient acreage on TVA property in the green area northeast of the generator (Figure 3) to support siting an SMR. However, TVA already holds an NRC early site permit for the Clinch River Site just 15 miles from the Bull Run site. This permit would probably negate any nearterm consideration of SMR siting at this location. However, longer term power needs using SMR or advanced non-LWR technologies could be considered at the Bull Run site. 


\subsection{CUMBERLAND FOSSIL PLANT}

The Cumberland Fossil Plant is located on approximately 700 acres on the south bank of Barkley Reservoir in Cumberland City, Tennessee. The two-unit station is the largest generating asset in the TVA coal fleet, boasting a maximum rated gross output of 2,470 megawatts ( $11^{\text {th }}$ largest in the United States). Construction on the plant began in 1968, and both units began commercial operation in 1973. Since 2004, both units have been equipped with wet limestone scrubbers capable of removing more than 90 percent of the sulfur dioxide from plant emissions [10]. Aerial imagery of the plant's topography is shown in Figure 7. State Road 233 runs along the waterfront of the plant.

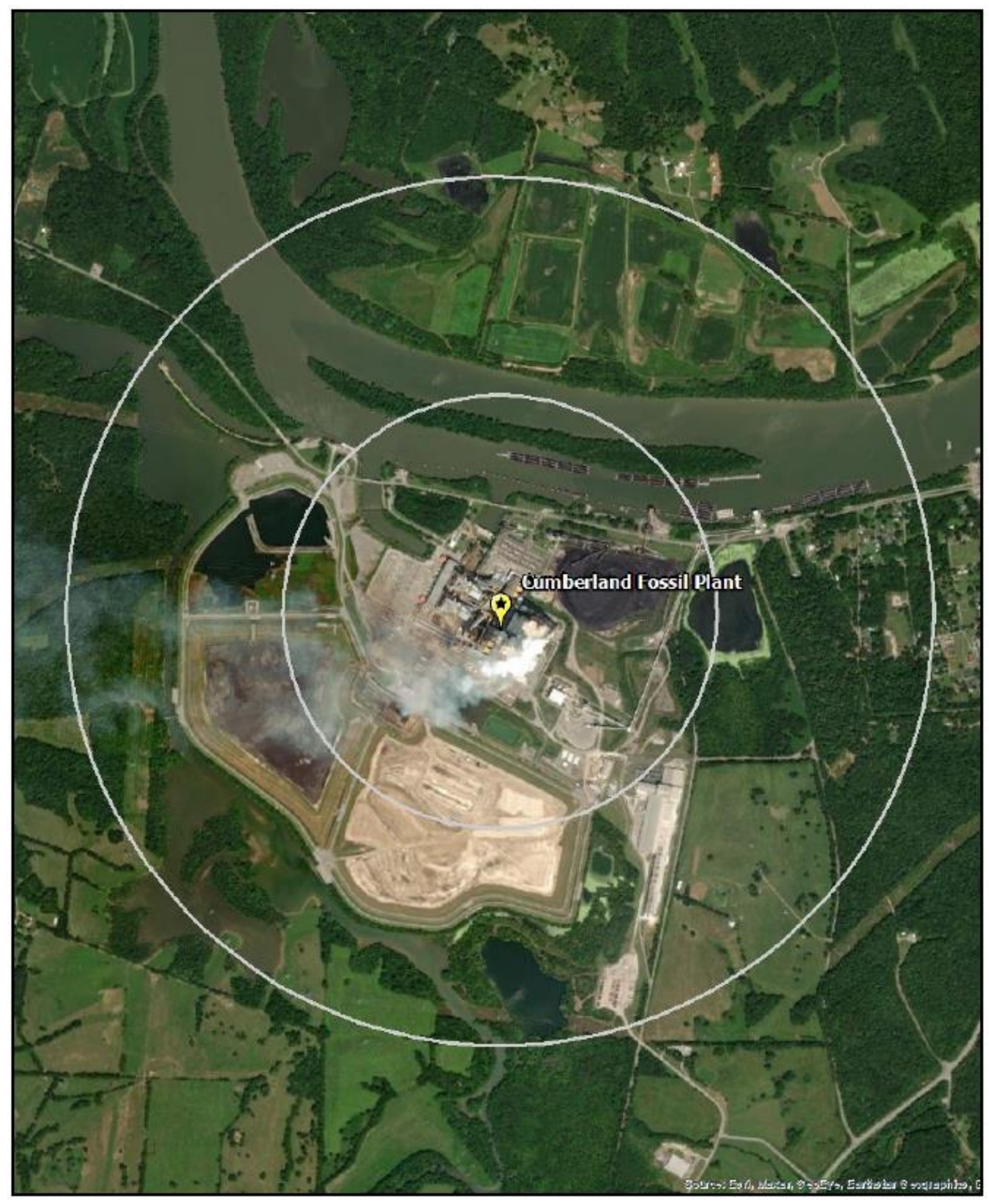

Figure 7. Satellite view of Cumberland Fossil Plant proximity. 


\subsubsection{Evaluation}

The screening results for the Cumberland site are listed in Table 2 and a composite map for the surrounding area is shown in Figure 8. The physical plant structures are located on land with no siting issues. Maps of the individual SMR siting criteria based on selected input values are also provided below.

Table 2. Cumberland Fossil Plant siting criteria summary

\begin{tabular}{|lc|}
\hline \multicolumn{2}{|c|}{ Screening Criteria Overview } \\
\hline Site: Cumberland Fossil Plant & State: TN \\
\hline
\end{tabular}

\begin{tabular}{|c|c|c|c|c|c|c|c|c|c|c|}
\hline \multicolumn{11}{|c|}{$\underset{\text { (Colored Boxes indicate Screening Results) }}{\text { Screening Criteria Summary }}$} \\
\hline \multicolumn{3}{|c|}{ No Siting Issue } & \multicolumn{4}{|c|}{ Partial Siting Issue } & \multicolumn{4}{|c|}{ Full Siting Issue } \\
\hline $\begin{array}{c}\text { Inside } \\
\text { the } 0.5 \\
\text { mile } \\
\text { Radius } \\
\end{array}$ & \begin{tabular}{|c|} 
Pop \\
Density
\end{tabular} & $\begin{array}{l}\text { Wet- } \\
\text { lands }\end{array}$ & $\begin{array}{c}\text { Protected } \\
\text { Lands }\end{array}$ & Landslide & \begin{tabular}{c|}
$100-$ yr \\
Flood- \\
plain
\end{tabular} & \begin{tabular}{|l|} 
Slope \\
$(18 \%)$
\end{tabular} & $\begin{array}{c}\text { Hazardous } \\
\text { Facilities }\end{array}$ & $\begin{array}{l}\text { Fault } \\
\text { Lines }\end{array}$ & 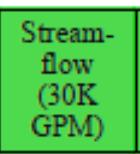 & $\begin{array}{c}\text { SSE } \\
(0.5 \mathrm{~g})\end{array}$ \\
\hline $\begin{array}{c}\text { Inside } \\
\text { the } \\
0.6 \text { to } 1- \\
\text { mile } \\
\text { Radius } \\
\end{array}$ & \begin{tabular}{|c|} 
Pop \\
Density
\end{tabular} & $\begin{array}{l}\text { Wet- } \\
\text { lands }\end{array}$ & $\begin{array}{c}\text { Protected } \\
\text { Lands }\end{array}$ & Landslide & \begin{tabular}{c|} 
100-yr \\
Flood- \\
plain
\end{tabular} & \begin{tabular}{|l|} 
Slope \\
$(18 \%)$
\end{tabular} & \begin{tabular}{|c|} 
Hazardous \\
Facilities
\end{tabular} & $\begin{array}{l}\text { Fault } \\
\text { Lines }\end{array}$ & $\begin{array}{l}\text { Stream- } \\
\text { flow } \\
(30 \mathrm{~K} \\
\text { GPM) }\end{array}$ & $\begin{array}{l}\text { SSE } \\
(0.5 \mathrm{~g})\end{array}$ \\
\hline \multicolumn{11}{|c|}{ Screening Criteria Table } \\
\hline \multicolumn{7}{|c|}{ Criteria } & \multicolumn{4}{|c|}{ Value } \\
\hline \multicolumn{7}{|c|}{ Population Density within 4 miles } & \multicolumn{4}{|c|}{$>500$ (people/square mile) } \\
\hline \multicolumn{7}{|c|}{ Wetlands and Open water are excluded } & \multicolumn{4}{|c|}{-} \\
\hline \multicolumn{7}{|c|}{ Protected lands are excluded } & \multicolumn{4}{|c|}{ - } \\
\hline \multicolumn{7}{|c|}{ Land with moderate/high landslide hazard susceptibility are excluded } & \multicolumn{4}{|c|}{-} \\
\hline \multicolumn{7}{|c|}{ Land that lies within a 100 -year floodplain is excluded } & \multicolumn{4}{|c|}{-} \\
\hline \multicolumn{7}{|l|}{ Slope } & \multicolumn{4}{|c|}{$>18 \%\left(\sim 10^{\circ}\right)$} \\
\hline \multicolumn{7}{|c|}{$\begin{array}{l}\text { Land located in proximity to hazardous facilities } \\
\text { (Airport - 5mi; Oil Refineries - } 1 \mathrm{mi} \text {; and Military Bases - } 1 \mathrm{mi} \text { ) }\end{array}$} & \multicolumn{4}{|c|}{-} \\
\hline \multicolumn{7}{|c|}{ Land too close to identified fault lines is avoided } & \multicolumn{4}{|c|}{ - } \\
\hline \multicolumn{7}{|c|}{ Streamflow within 20 miles } & \multicolumn{4}{|c|}{$\geq 30,000 \mathrm{gpm}$} \\
\hline \multicolumn{7}{|c|}{ Safe-shutdown earthquake peak ground acceleration } & \multicolumn{4}{|c|}{$\geq 0.5 \mathrm{~g}$} \\
\hline
\end{tabular}




\section{Site Characterization: Composite Map}

Site: Cumberland Fossil Plant

State: TN

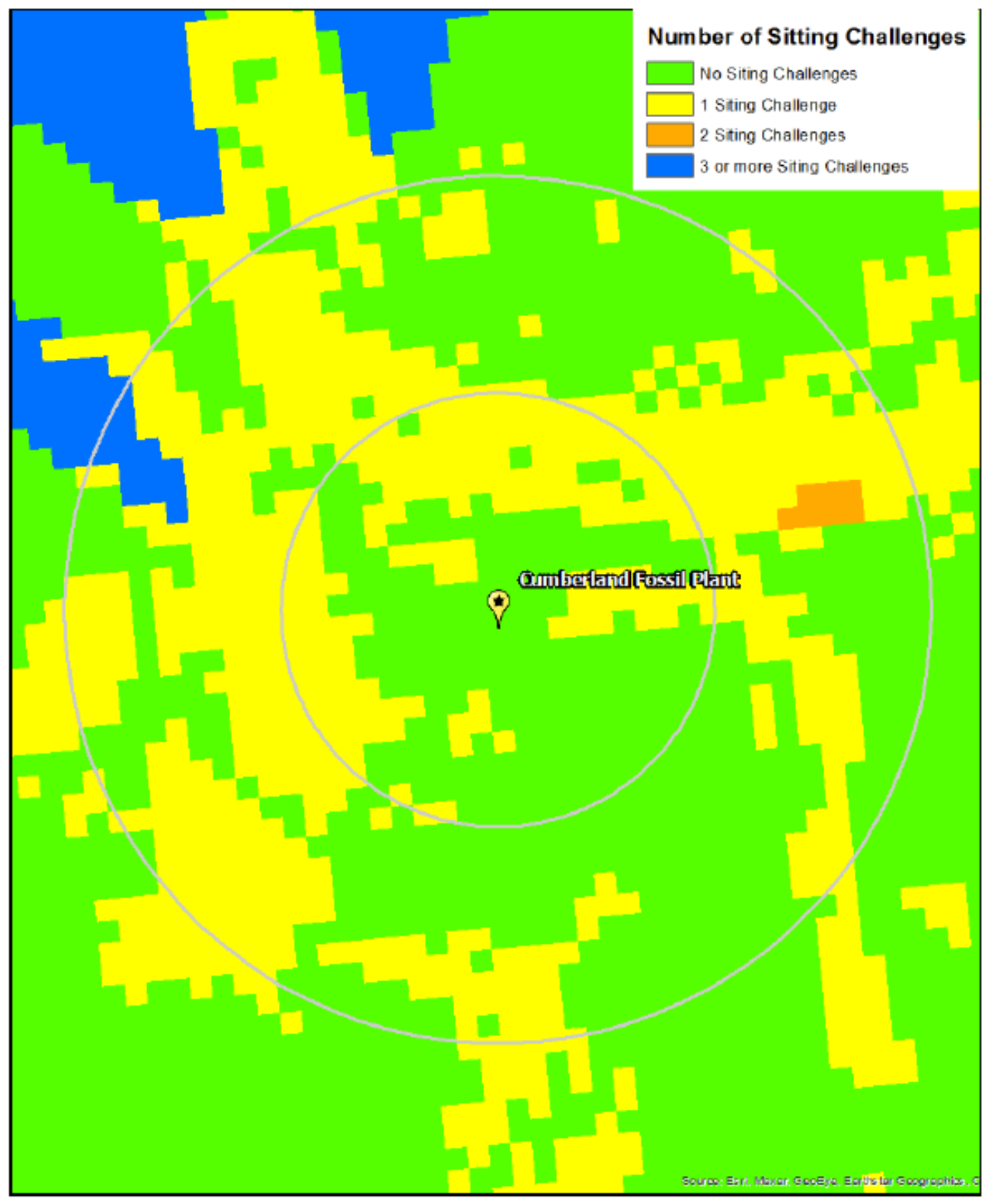

Figure 8. Cumberland Fossil Plant composite map. 

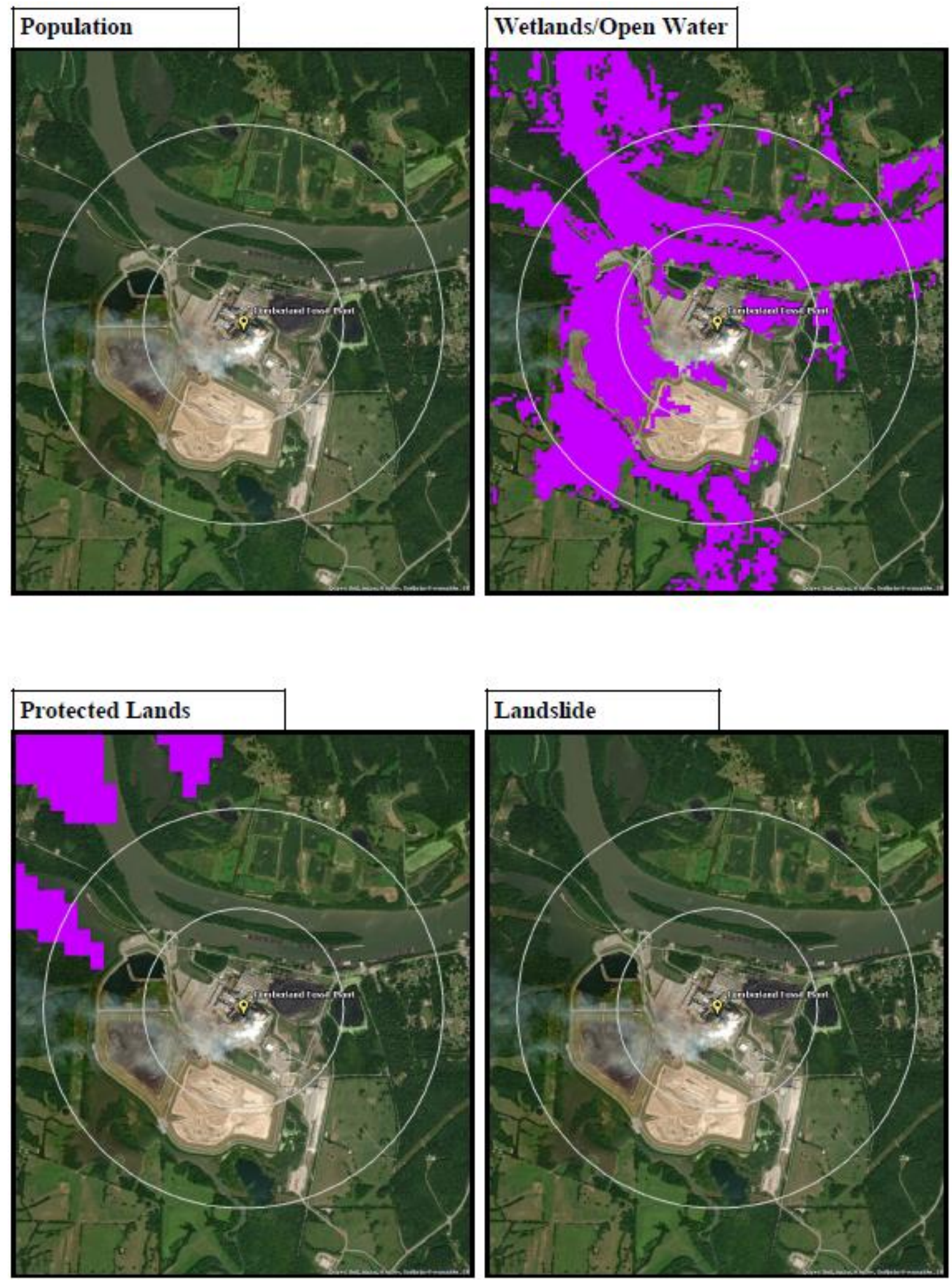

Figure 9. Cumberland Fossil Plant siting criteria maps showing population, wetlands/open water, protected lands, and landslide. 

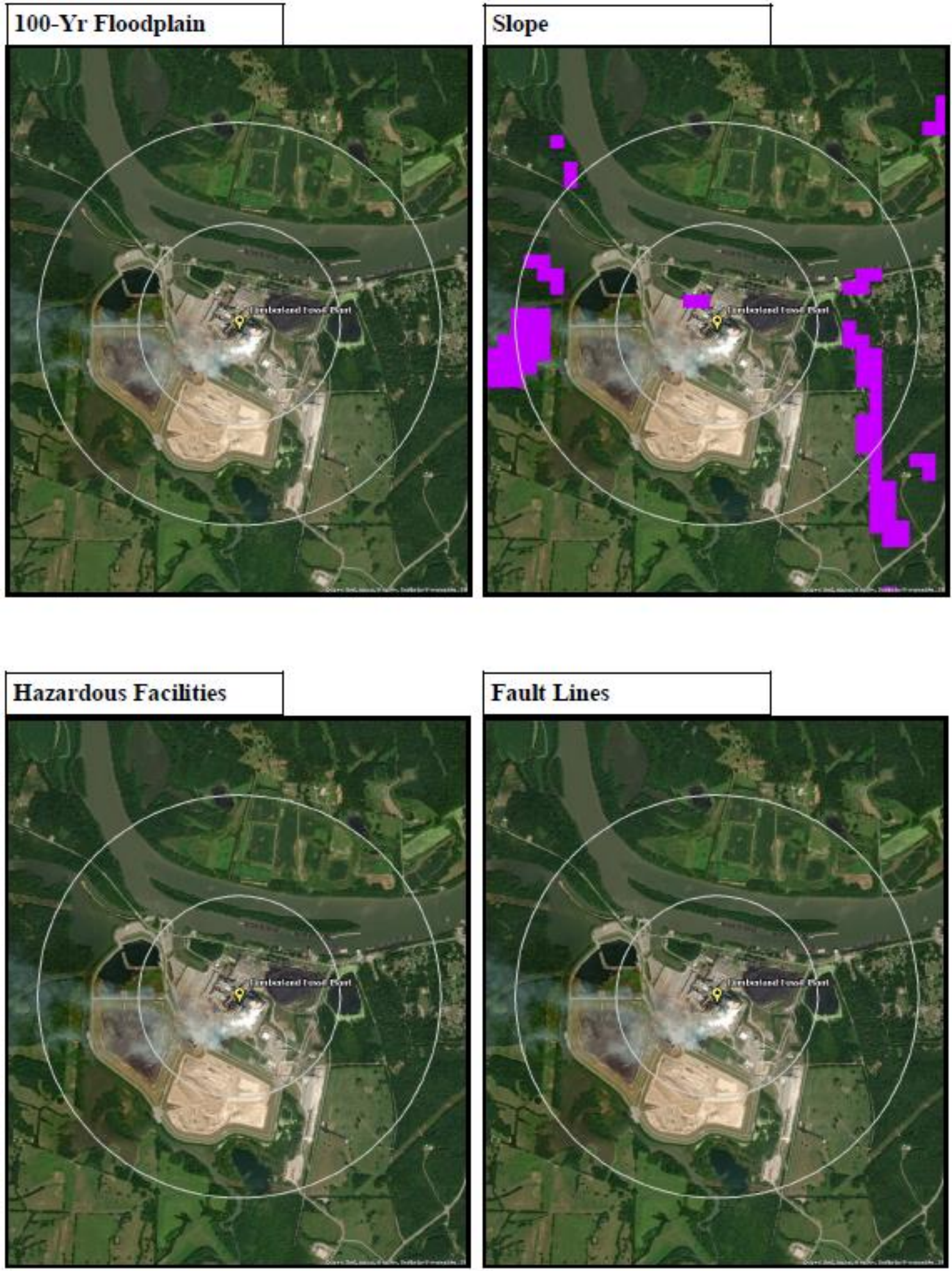

Figure 10. Cumberland Fossil Plant siting criteria maps showing 100-year floodplain, slope, hazardous facilities, and fault lines. 

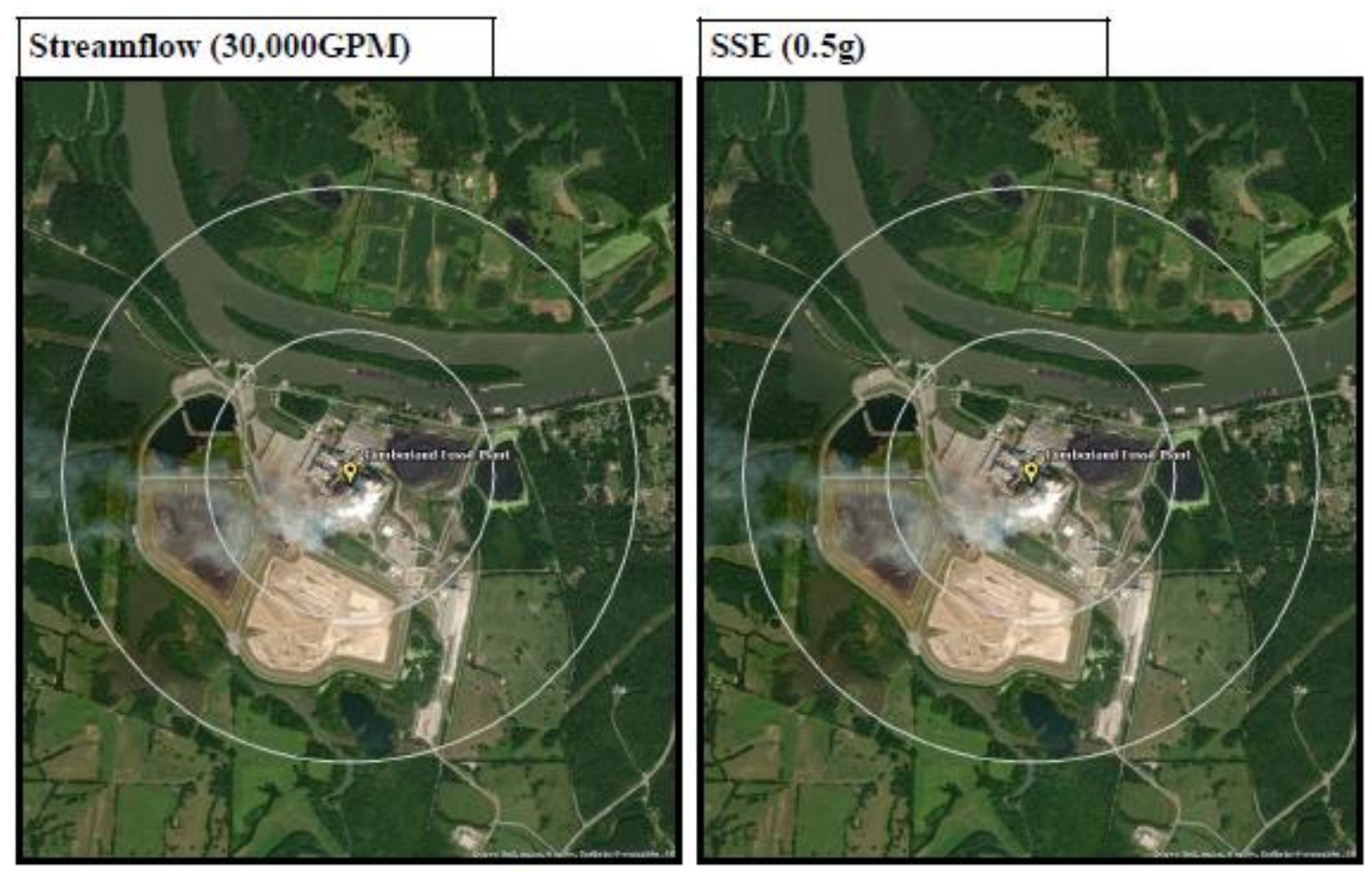

Figure 11. Cumberland Fossil Plant siting criteria maps showing streamflow and SSE.

\subsubsection{Summary}

According to ClarksvilleNow.com, ${ }^{1}$ TVA is considering retiring the two coal-fired units at Cumberland and replacing them with natural gas or a combination of gas, solar, and storage facilities, on the same location or at an alternate site. Replacement facilities could require a natural gas pipeline and transmission upgrades, depending on the facilities.

The Cumberland Fossil Plant is about one mile west of Cumberland City, Tennessee. The small population of Cumberland City poses no population density concerns to the plant site for an advanced reactor technology with a small source term.

Open water and slope also cross the site, posing issues associated with a plant on a body of water. In addition, the Riverbend Recreation Area and some other protected lands lie northwest of the Cumberland site.

As shown in in Figure 8, the Cumberland site contains significant acreage (indicated in green) on TVA property to support siting an SMR. When future environmental concerns dictate removing the Cumberland Fossil Plant from the grid, TVA could easily make the case for siting an advanced reactor technology at this location. The site appears reasonably isolated, and it meets multiple conventional standards for consideration of siting an SMR at the coal station location. There are no foreseeable current or near-term SMR siting parameter issues that would preclude this site from further SMR siting consideration.

\footnotetext{
${ }^{1}$ https://clarksvillenow.com/local/tva-considers-plan-to-retire-replace-cumberland-fossil-plant-southwest-of-clarksville/
} 


\subsection{GALLATIN FOSSIL PLANT}

The Gallatin Fossil Plant is located on 1,950 acres on the north bank of the Cumberland River in Sumner County, Tennessee. Construction on the four turbo-generating units started in 1953, and the generators went into operation between 1956 and 1959. The coal-fired portion of the station has a combined summer net generating capacity of 976 megawatts. A selective catalytic reduction system to reduce nitrogen oxide emissions and scrubbers to reduce sulfur dioxide emissions were installed on all four Gallatin units in 2016. Four gas-fired units were added to the site in 1975, and an additional four gas-fired units were added in 2000 [10]. Aerial imagery of the plant's topography is shown in Figure 12.

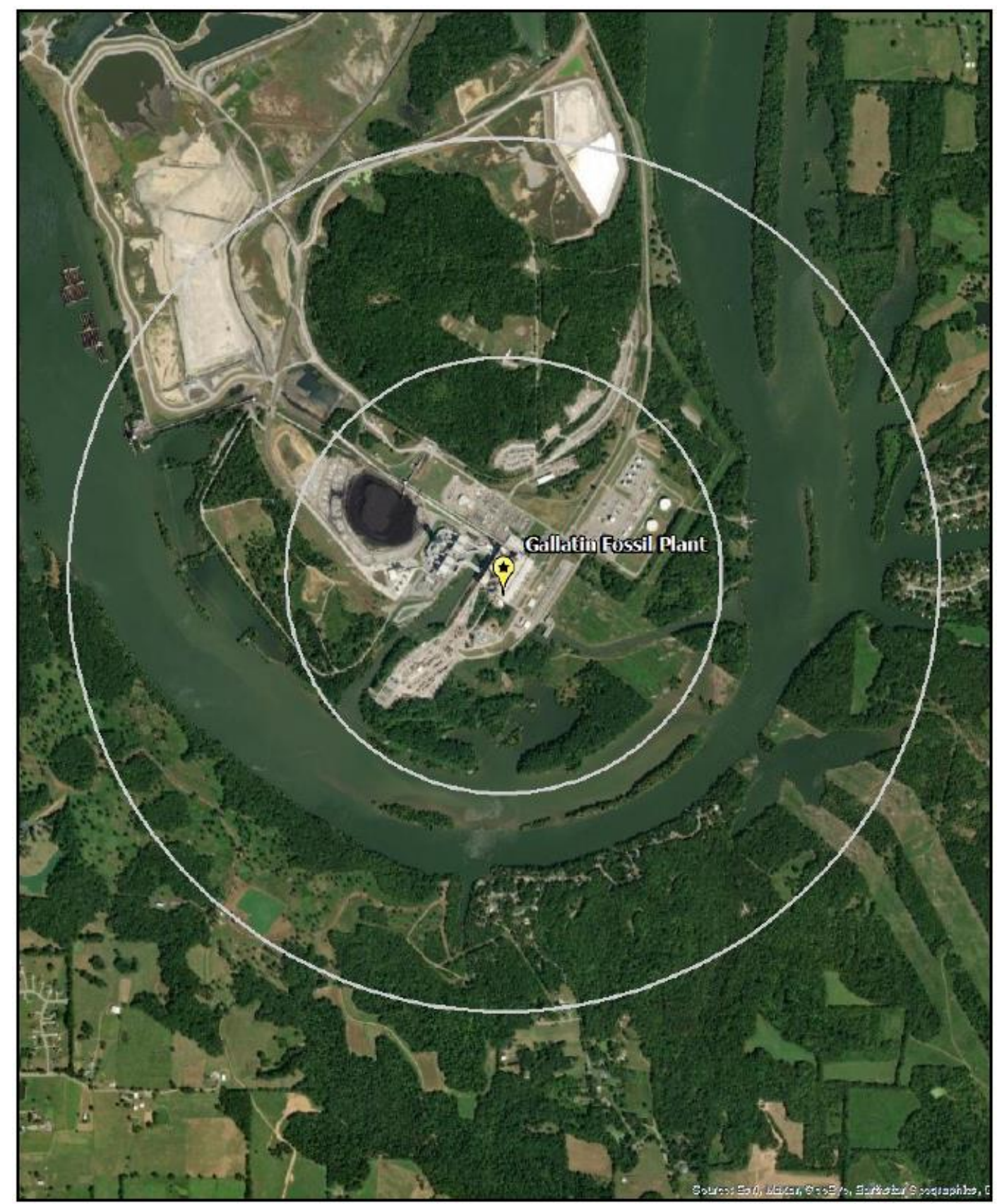

Figure 12. Satellite view of Gallatin Fossil Plant proximity. 


\subsubsection{Evaluation}

The screening results for the Gallatin site are listed in Table 3, and a composite map for the surrounding area is shown in Figure 13. The physical plant structures are located on land, with no siting issues. Maps of the individual SMR siting criteria based on selected input values are also provided below.

Table 3. Gallatin Fossil Plant siting criteria summary

\section{Screening Criteria Overview}

Site: Gallatin Fossil Plant

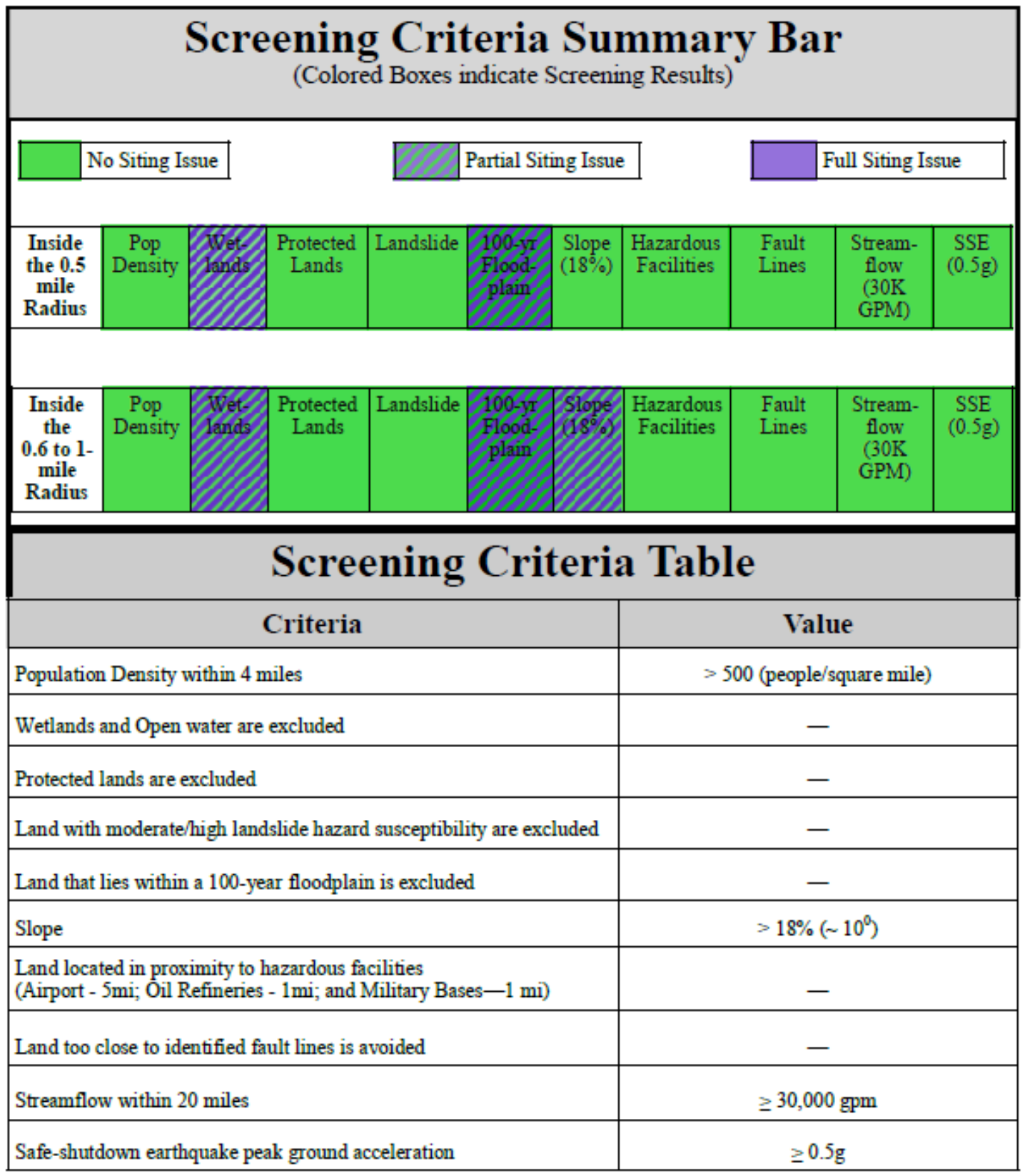




\section{Site Characterization: Composite Map}

Site: Gallatin Fossil Plant

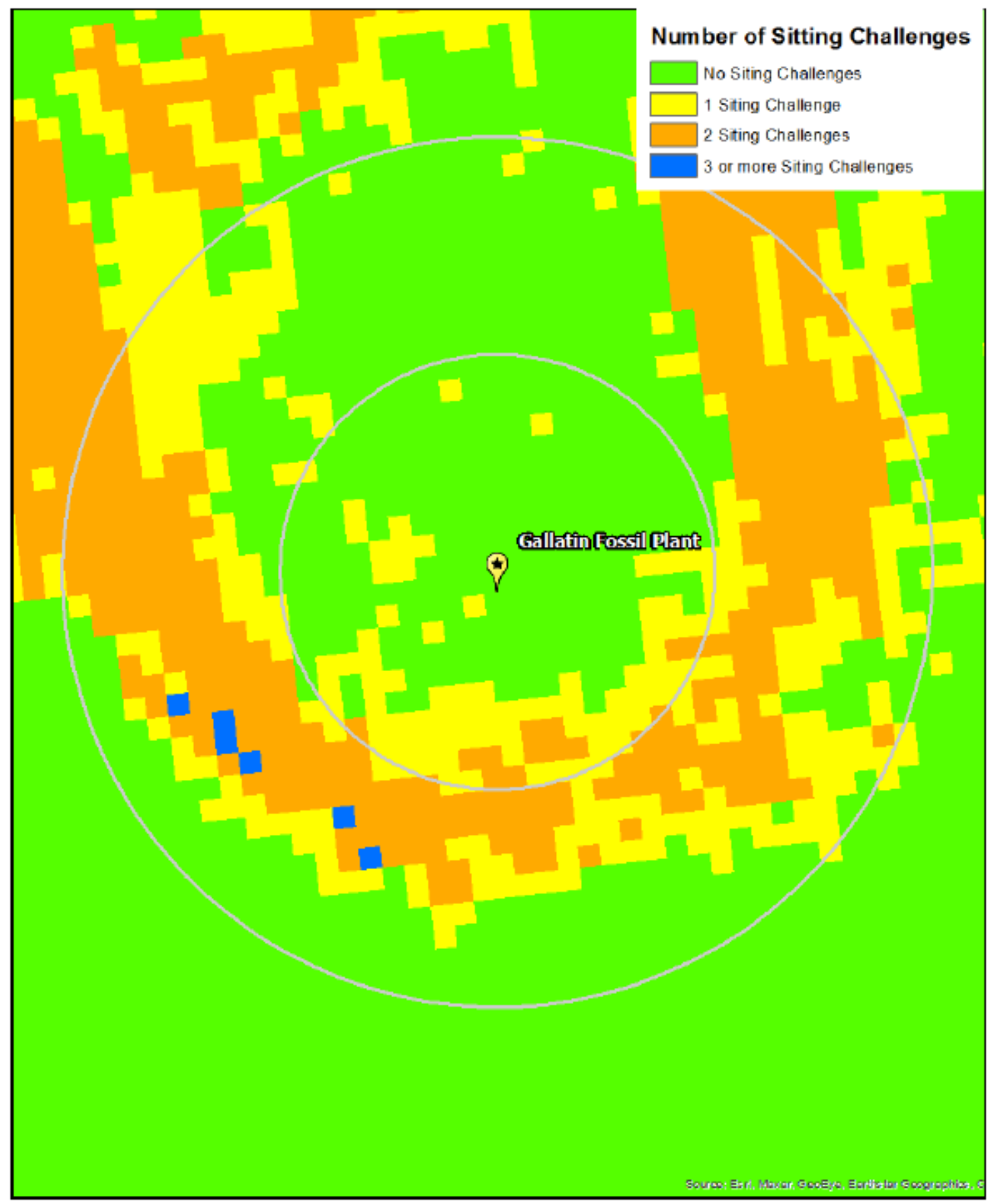

Figure 13. Gallatin Fossil Plant composite map. 

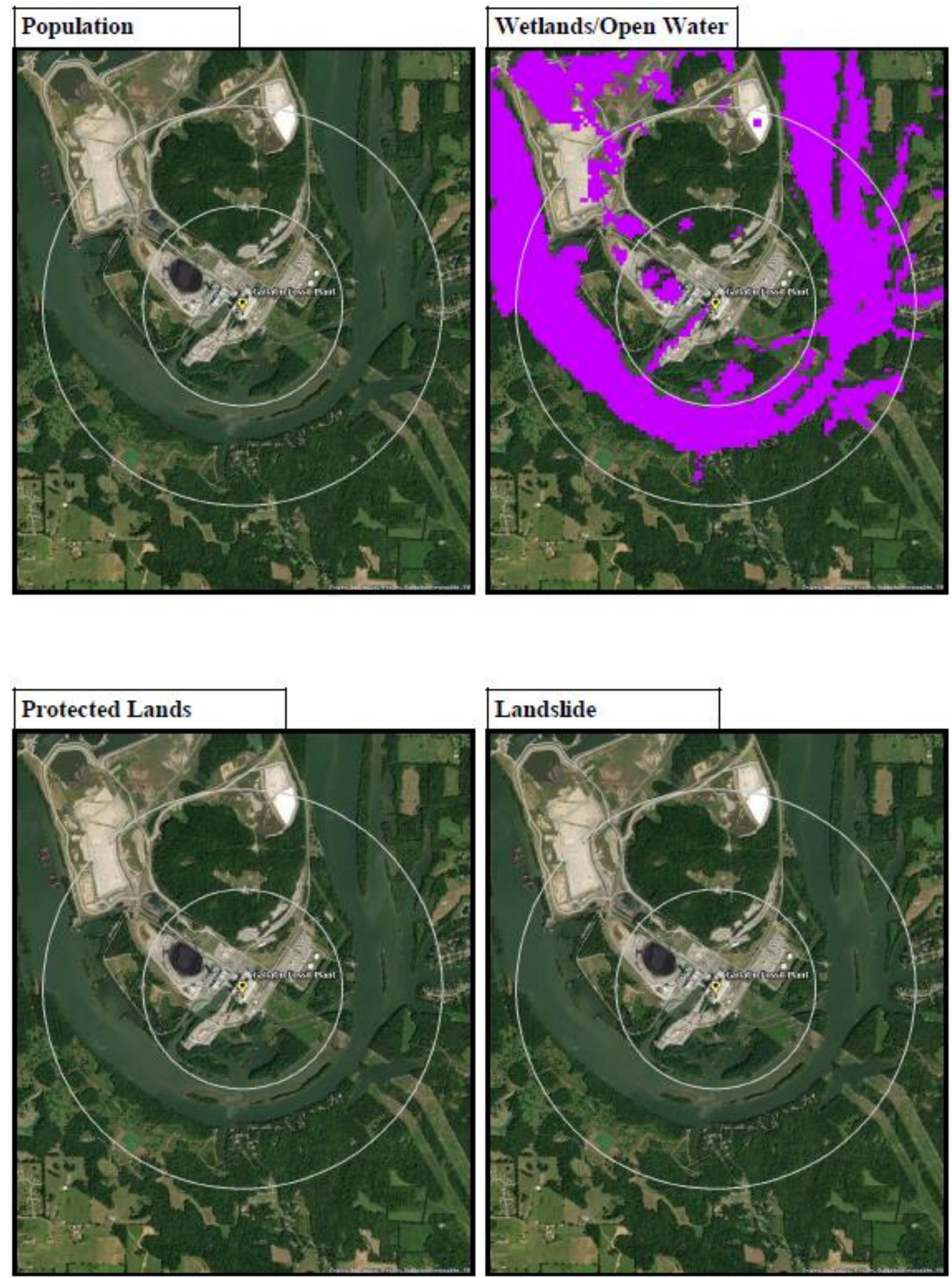

Figure 14. Gallatin Fossil Plant siting criteria maps showing population, wetlands/open water, protected lands, and landslide. 

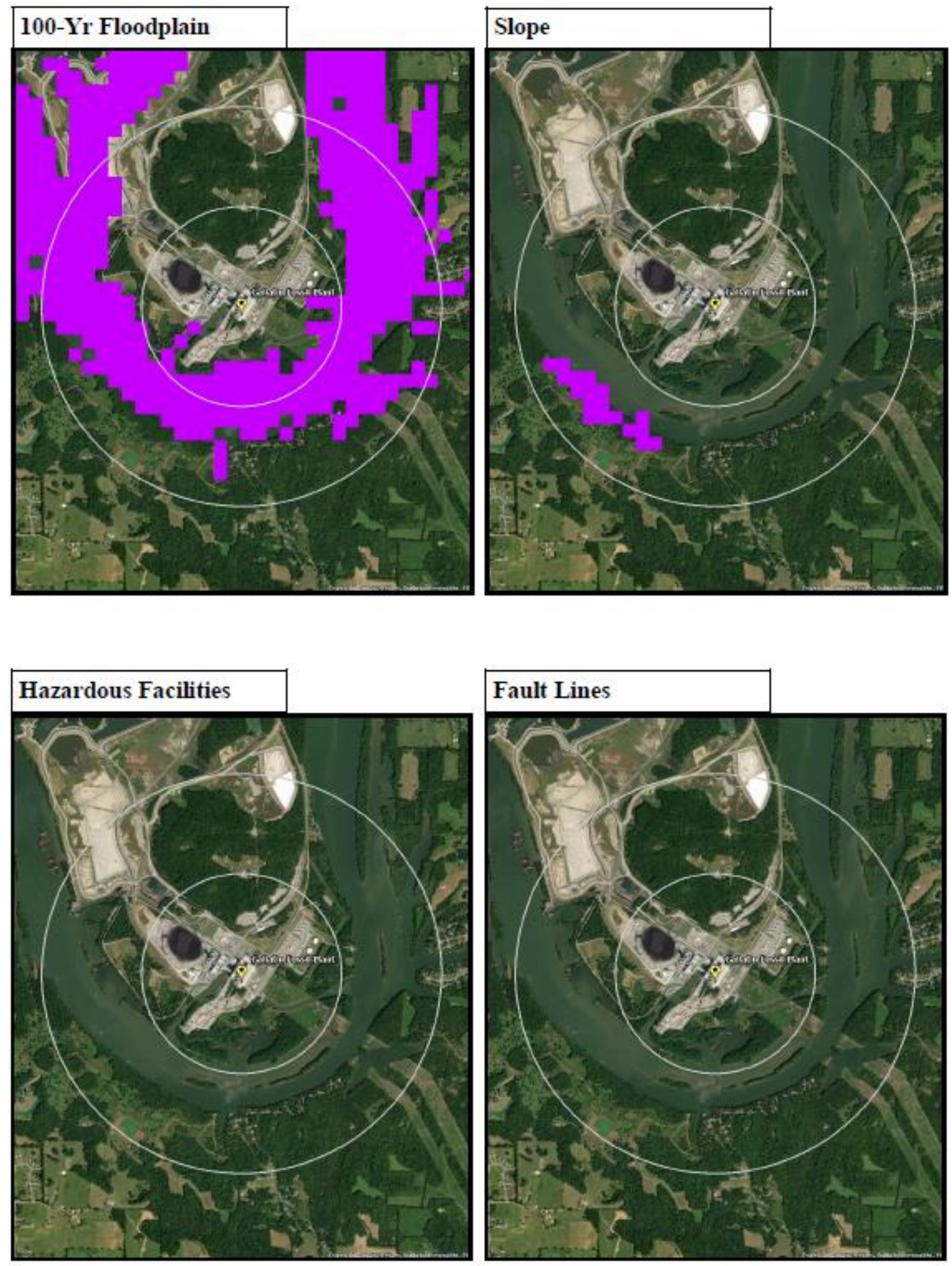

Figure 15. Gallatin Fossil Plant siting criteria maps showing 100-year floodplain, slope, hazardous facilities, and fault lines. 

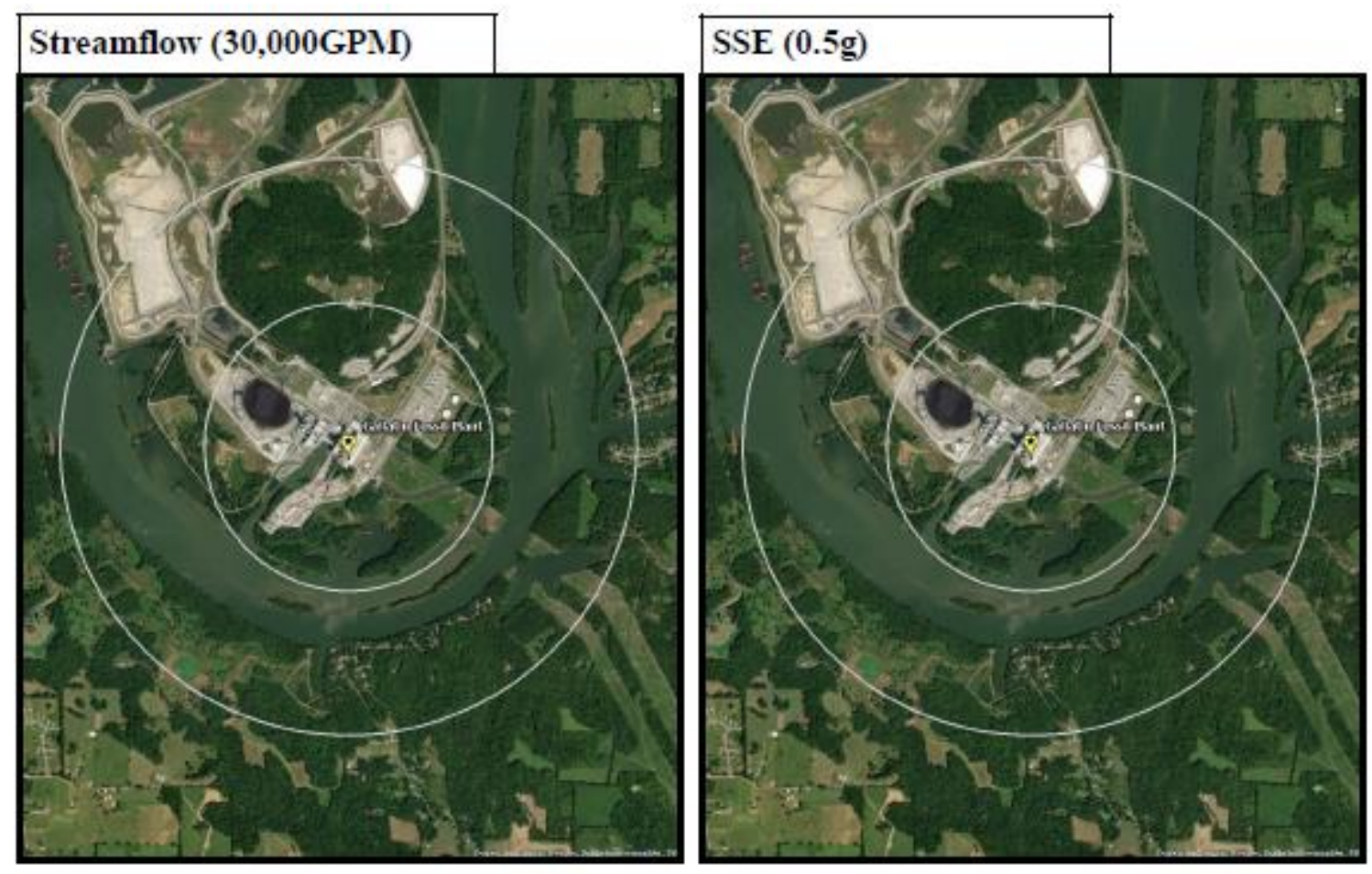

Figure 16. Gallatin Fossil Plant siting criteria maps showing streamflow and SSE.

\subsubsection{Summary}

The Gallatin Fossil Plant is about 5 miles south of Gallatin, Tennessee. The small rural population of the area poses no population density concerns to the plant site for an advanced reactor technology with a small source term.

Although it is not shown as a hazard on the hazardous facilities criteria map, the Sumner County Regional Airport is approximately 4 miles north of the Gallatin site. The single runway is aligned with the plant site. Since the airport is classified as a general aviation airport, it does not require specific analysis per RG 4.7. However, the proximity and runway alignment make it prudent to gather and analyze data on flight frequency and typical plane size.

The site sits on a horseshoe bend in the Cumberland River. With the exception of the floodplain area along the river's edge, as shown in Figure 13, the Gallatin site contains significant acreage (indicated in green) on TVA property to support siting an SMR. Despite the airport's location, when future environmental concerns dictate removing the Gallatin Fossil Plant from the grid, TVA could easily make the case for siting an advanced reactor technology there. The site appears reasonably isolated, and it meets multiple conventional standards for consideration of siting an SMR at the coal station location. There are no foreseeable current or near-term SMR siting parameter issues that would preclude this site from further SMR siting consideration. 


\subsection{KINGSTON FOSSIL PLANT}

The Kingston Fossil Plant is located on 1,700 acres on the Watts Bar Reservoir on the Tennessee River near Kingston, Tennessee. Construction on the nine generating units started in 1951, and the last of the generators went into operation in 1955, ostensibly to provide power to the nearby Oak Ridge National Laboratory. It was the largest coal-fired power plant in the world at the time of its completion. The station has a combined summer net generating capacity of 1,398 megawatts. A selective catalytic reduction system to reduce nitrogen oxide emissions and scrubbers to reduce sulfur dioxide emissions were installed on all nine Kingston units in 2007 [10]. Aerial imagery of the plant's topography is shown in Figure 17. Interstate 40 runs within 0.75 miles of the plant.

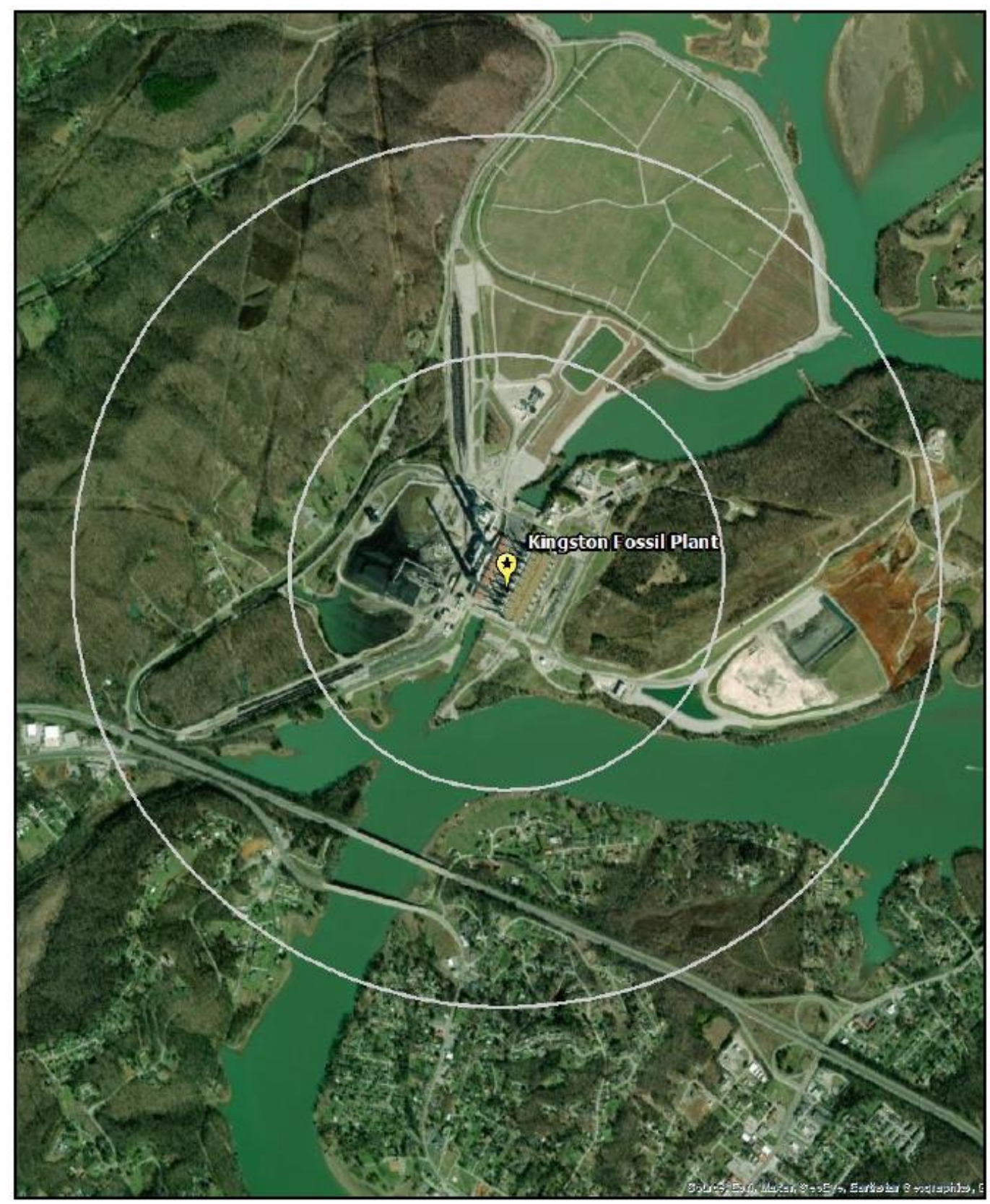

Figure 17. Satellite view of Kingston Fossil Plant proximity. 


\section{Site Characterization: Composite Map}

\section{Site: Kingston Fossil Plant}

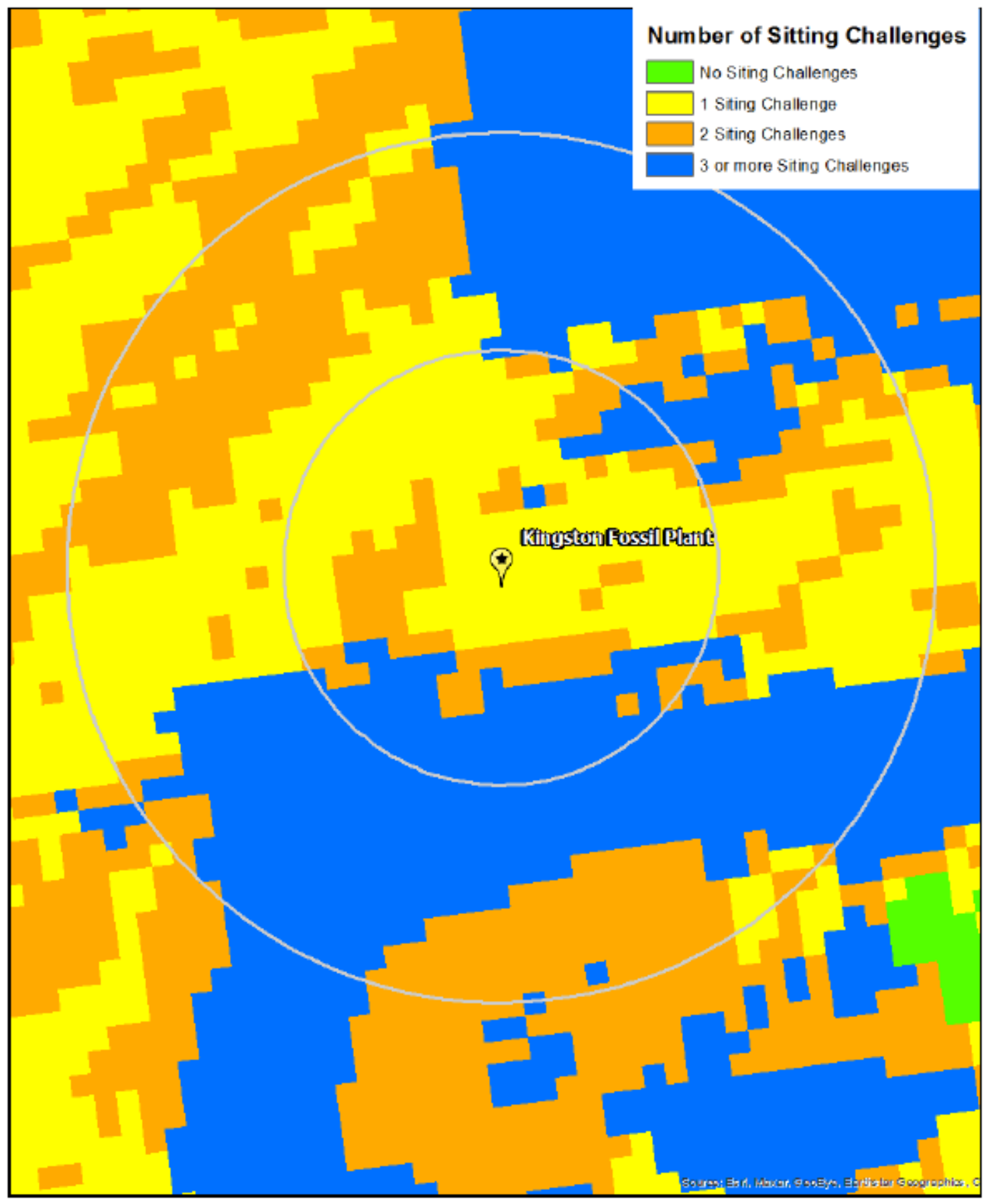

Figure 18. Kingston Fossil Plant composite map.
State: TN 

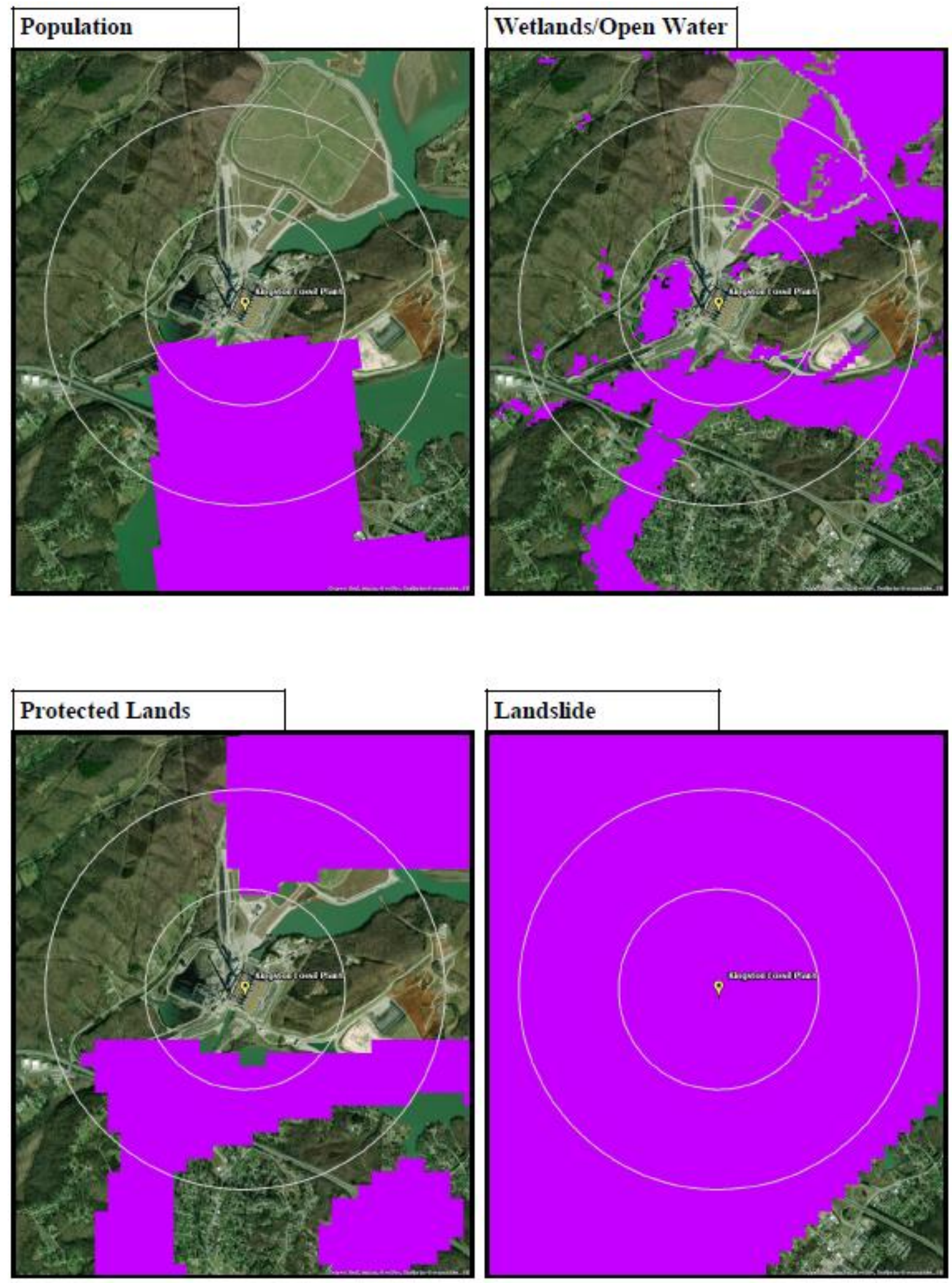

Figure 19. Kingston Fossil Plant siting criteria maps showing population, wetlands/open water, protected lands, and landslide. 

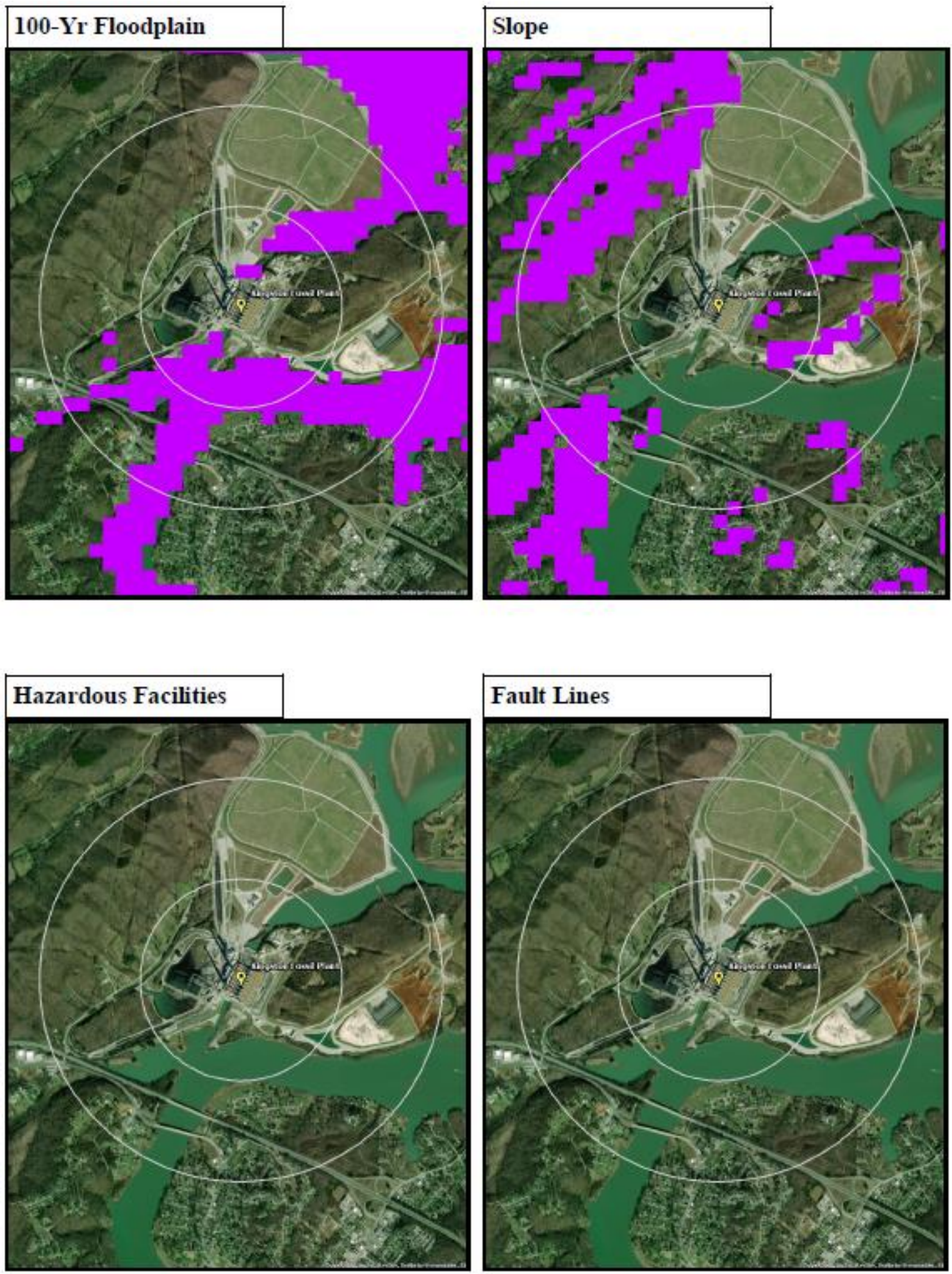

Figure 20. Kingston Fossil Plant siting criteria maps showing 100-year floodplain, slope, hazardous facilities, and fault lines. 


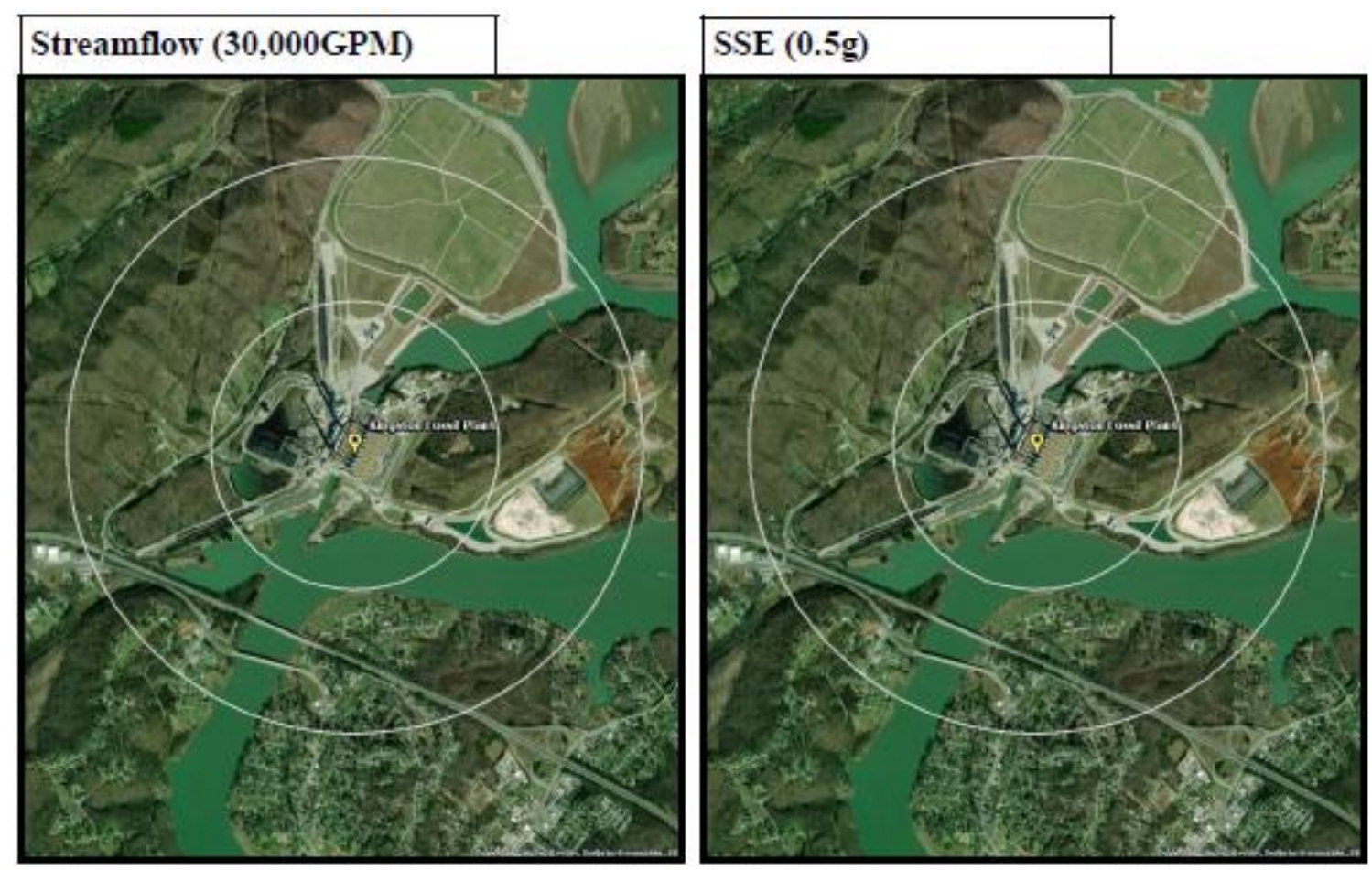

Figure 21. Kingston Fossil Plant siting criteria maps showing streamflow and SSE.

\subsubsection{Summary}

The Kingston Fossil Plant is about one mile north of Kingston, Tennessee, and 3 miles southeast of Harriman, Tennessee. The population of Kingston creates a population density concern relative to the query setpoint on the south side of the plant site.

Open water, slope, and floodplain around the borders of the site pose issues associated with a plant on a body of water. In addition, churches north and south of the generator, as well as the Watts Bar Reservoir, provide some protected land to be considered for SMR siting.

The most prominent SMR siting flag is for landslide risk. As noted in Section 2.1, landslide is a flag based on broad-based risk assessments conducted by the USGS. This analysis simply highlights the need for in-depth geological evaluations at the site. Some evaluation may already be available from the environmental qualification of the coal plant.

If the landslide hazard flag can be eliminated based on more informed geological data, then the Kingston site does contain sufficient acreage on TVA property to support siting an SMR. Without the landslide flag, most of the yellow area shown in Figure 18 becomes suitable for an SMR siting. However, TVA already holds an NRC early site permit for the Clinch River Site just 8 miles from the Kingston site. This would probably negate any near-term consideration of SMR siting at this location. However, longer term power needs using SMR or advanced non-LWR technology could be considered at the Kingston site. 


\subsection{SHAWNEE FOSSIL PLANT}

The Shawnee Fossil Plant is located on 1,696 acres on the south bank of the Ohio River northwest of Paducah, Kentucky, and across the river from Metropolis, Illinois, and the Honeywell Uranium Conversion Plant. Construction on the 10 generating units started in 1951, and they went into operation between 1953 and 1956. The station has a combined summer net generating capacity of 1,206 megawatts. A selective catalytic reduction system to reduce nitrogen oxide emissions and scrubbers to reduce sulfur dioxide emissions are currently being installed on units 1-4 [10]. Aerial imagery of the plant's topography is shown in Figure 22.

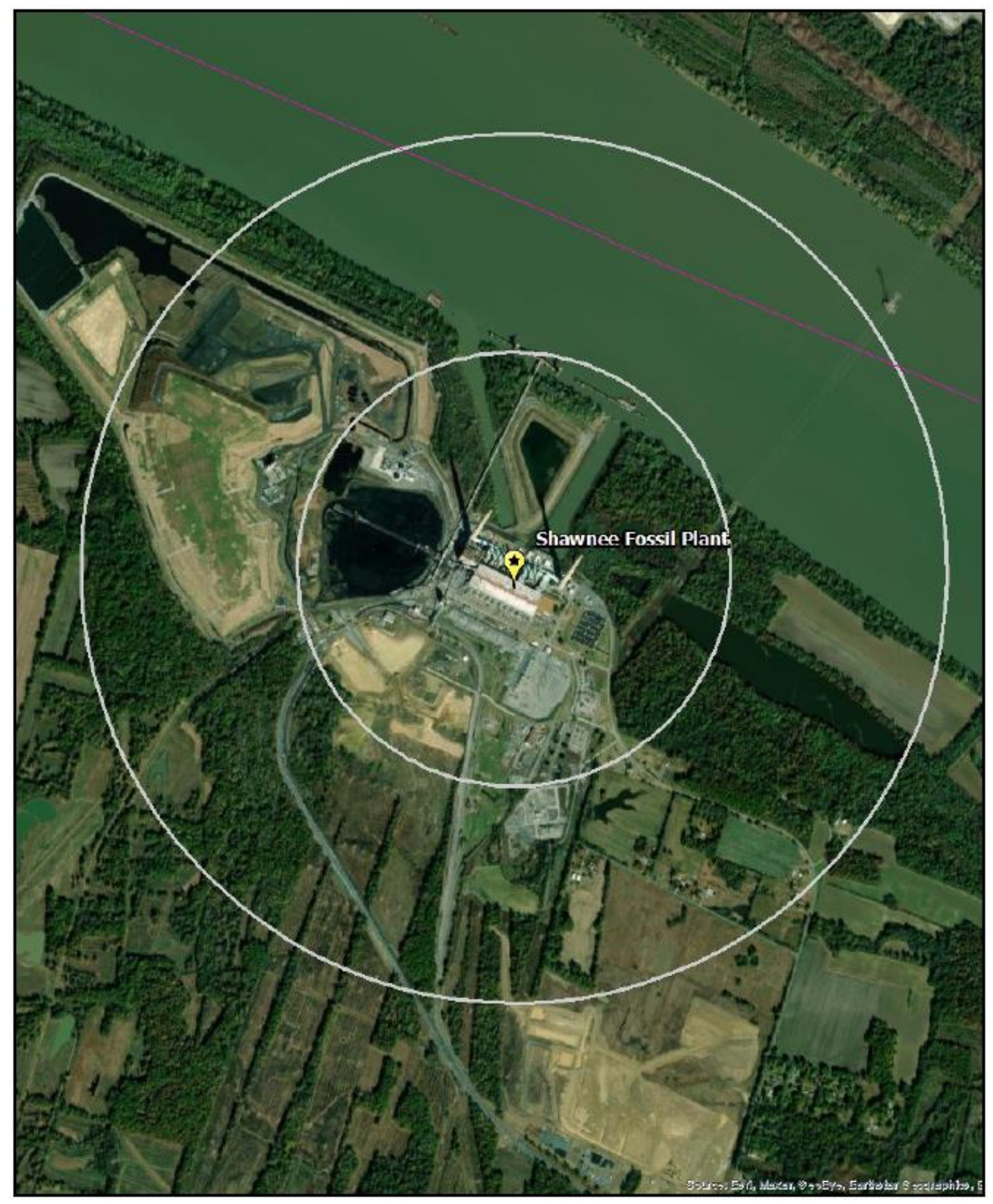

Figure 22. Satellite view of Shawnee Fossil Plant proximity. 


\subsubsection{Evaluation}

The screening results for the Shawnee site are listed in Table 5, and a composite map for the surrounding area is shown in Figure 23. The physical plant structures are located on land, with one siting issue. Maps of the individual SMR siting criteria based on selected input values are also provided below.

Table 5. Shawnee Fossil Plant siting criteria summary

\begin{tabular}{|l|}
\hline \multicolumn{2}{|c|}{ Screening Criteria Overview } \\
\hline Site: Shawnee Fossil Plant $\quad$ State: $\mathrm{KY}$ \\
\hline
\end{tabular}

\begin{tabular}{|c|c|c|c|c|c|c|c|c|c|c|}
\hline \multicolumn{11}{|c|}{ Screening Criteria Summary Bar } \\
\hline \multicolumn{3}{|c|}{ No Siting Issue } & \multicolumn{4}{|c|}{ Partial Siting Issue } & \multicolumn{4}{|c|}{ Full Siting Issue } \\
\hline $\begin{array}{c}\text { Inside } \\
\text { the } 0.5 \\
\text { mile } \\
\text { Radius } \\
\end{array}$ & \begin{tabular}{|c|} 
Pop \\
Density
\end{tabular} & \begin{tabular}{|l|} 
Wet- \\
lands \\
\end{tabular} & \begin{tabular}{|c|} 
Protected \\
Lands
\end{tabular} & Landslide & \begin{tabular}{c|}
$100-y 1$ \\
Flood- \\
plain
\end{tabular} & $\begin{array}{l}\text { Slope } \\
(18 \%)\end{array}$ & \begin{tabular}{|c|} 
Hazardous \\
Facilities
\end{tabular} & $\begin{array}{l}\text { Fault } \\
\text { Lines }\end{array}$ & $\begin{array}{c}\text { Stream- } \\
\text { flow } \\
\text { (30K } \\
\text { GPM) } \\
\end{array}$ & $\begin{array}{l}\text { SSE } \\
(0.5 \mathrm{~g})\end{array}$ \\
\hline \begin{tabular}{|c} 
Inside \\
the \\
0.6 to $1-$ \\
mile \\
Radius \\
\end{tabular} & \begin{tabular}{|c|} 
Pop \\
Density
\end{tabular} & $\begin{array}{l}\text { Wet- } \\
\text { lands }\end{array}$ & \begin{tabular}{c|} 
Protected \\
Lands
\end{tabular} & Landslide & $\begin{array}{l}\text { 100-yr } \\
\text { Flood- } \\
\text { plain }\end{array}$ & $\begin{array}{l}\text { Slope } \\
(18 \%)\end{array}$ & \begin{tabular}{|c|} 
Hazardous \\
Facilities
\end{tabular} & $\begin{array}{l}\text { Fault } \\
\text { Lines }\end{array}$ & $\begin{array}{l}\text { Stream- } \\
\text { flow } \\
\text { (30K } \\
\text { GPM) }\end{array}$ & $\begin{array}{c}\text { SSE } \\
(0.5 \mathrm{~g})\end{array}$ \\
\hline \multicolumn{11}{|c|}{ Screening Criteria Table } \\
\hline \multicolumn{7}{|c|}{ Criteria } & \multicolumn{4}{|c|}{ Value } \\
\hline \multicolumn{7}{|c|}{ Population Density within 4 miles } & \multicolumn{4}{|c|}{$>500$ (people/square mile) } \\
\hline \multicolumn{7}{|c|}{ Wetlands and Open water are excluded } & \multicolumn{4}{|c|}{-} \\
\hline \multicolumn{7}{|c|}{ Protected lands are excluded } & \multicolumn{4}{|c|}{-} \\
\hline \multicolumn{7}{|c|}{ Land with moderate/high landslide hazard susceptibility are excluded } & \multicolumn{4}{|c|}{-} \\
\hline \multicolumn{7}{|c|}{ Land that lies within a 100 -year floodplain is excluded } & \multicolumn{4}{|c|}{-} \\
\hline \multicolumn{7}{|l|}{ Slope } & \multicolumn{4}{|c|}{$>18 \%\left(\sim 10^{\circ}\right)$} \\
\hline \multicolumn{7}{|c|}{$\begin{array}{l}\text { Land located in proximity to hazardous facilities } \\
\text { (Airport - } 5 \mathrm{mi} \text {; Oil Refineries - } 1 \mathrm{mi} \text {; and Military Bases }-1 \mathrm{mi} \text { ) }\end{array}$} & \multicolumn{4}{|c|}{-} \\
\hline \multicolumn{7}{|c|}{ Land too close to identified fault lines is avoided } & \multicolumn{4}{|c|}{-} \\
\hline \multicolumn{7}{|c|}{ Streamflow within 20 miles } & \multicolumn{4}{|c|}{$\geq 30,000 \mathrm{gpm}$} \\
\hline \multicolumn{7}{|c|}{ Safe-shutdown earthquake peak ground acceleration } & \multicolumn{4}{|c|}{$\geq 0.5 \mathrm{~g}$} \\
\hline
\end{tabular}




\section{Site Characterization: Composite Map}

Site: Shawnee Fossil Plant

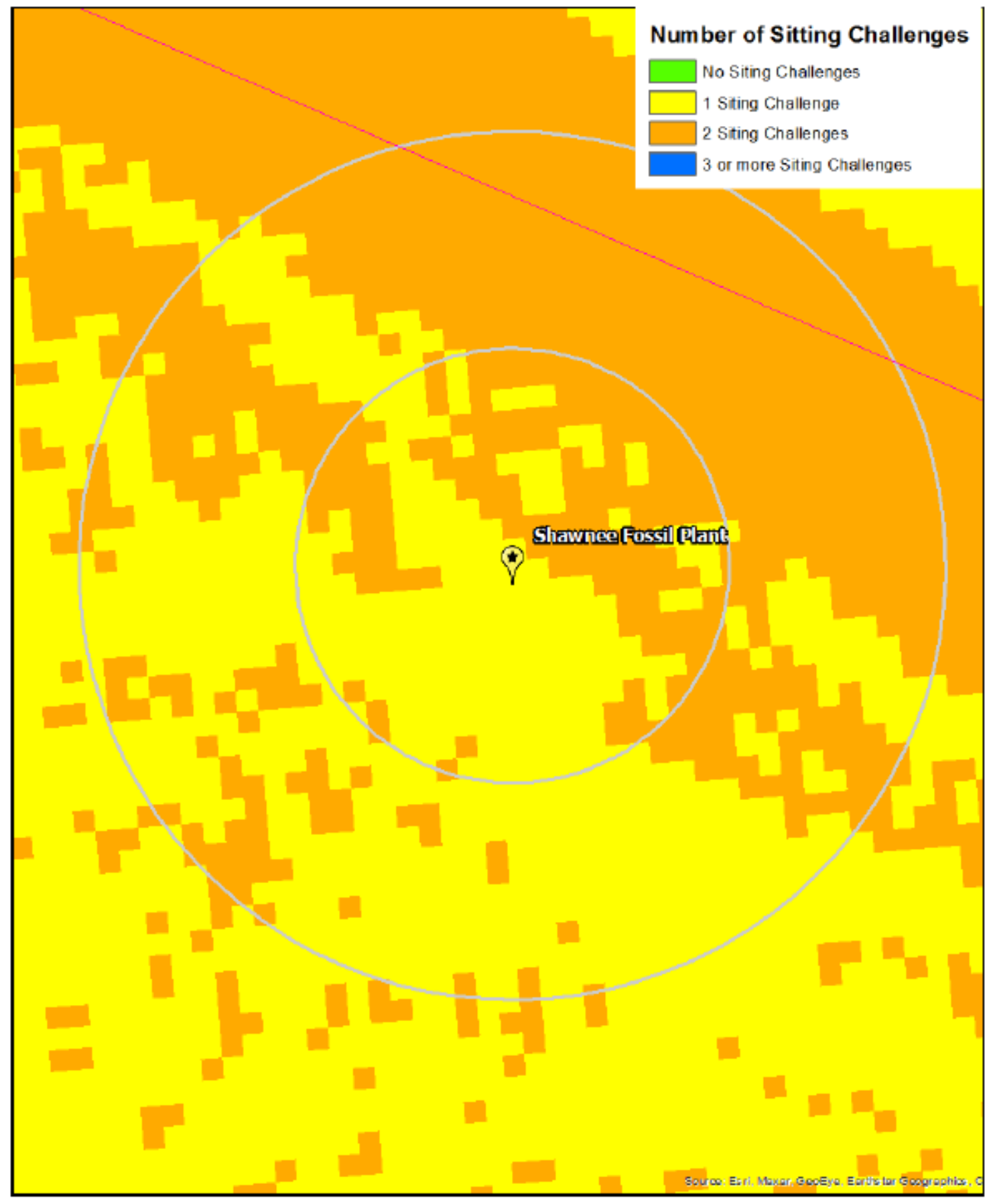

Figure 23. Shawnee Fossil Plant composite map.
State: KY 

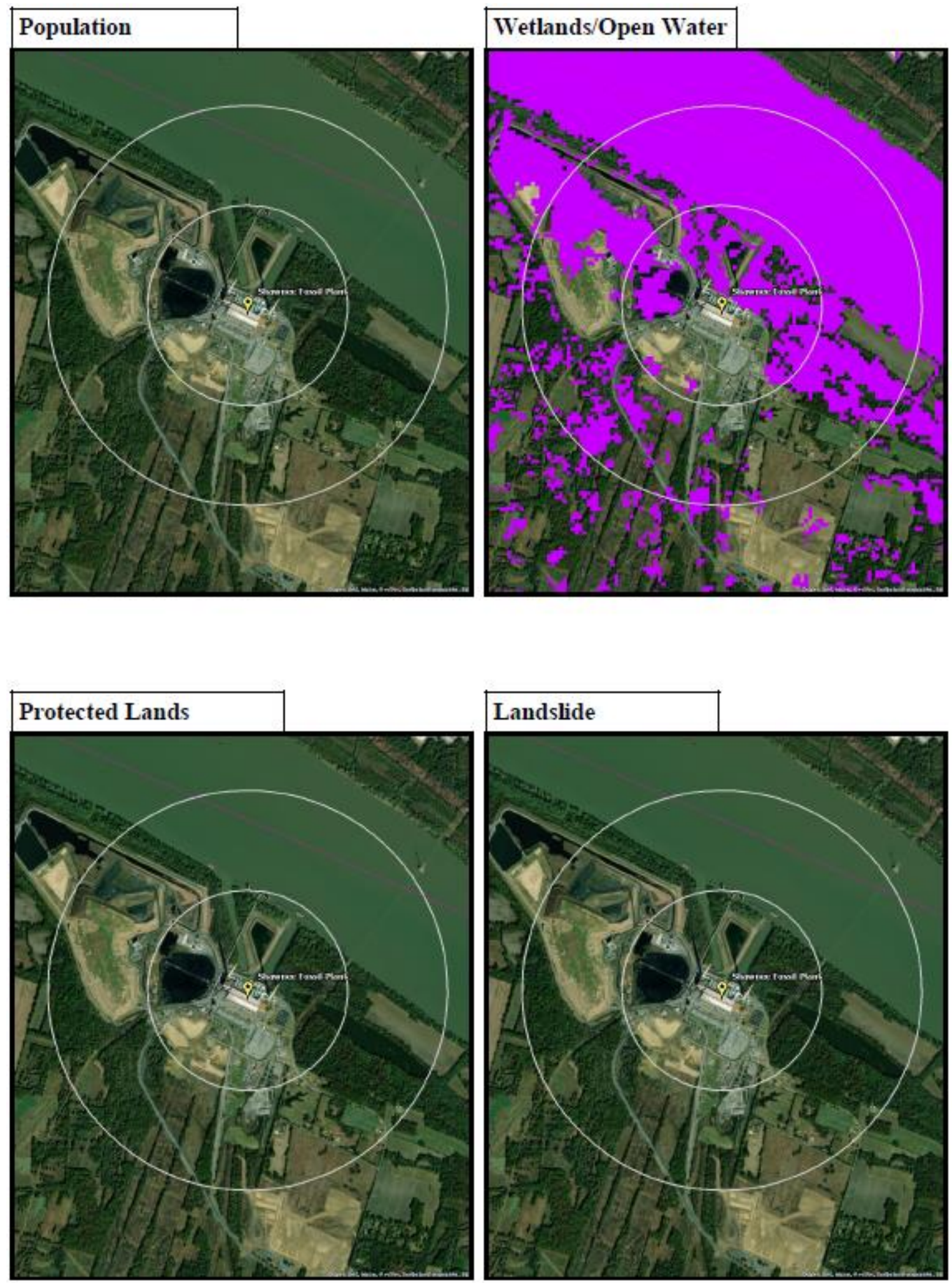

Figure 24. Shawnee Fossil Plant siting criteria maps showing population, wetlands/open water, protected lands, and landslide. 

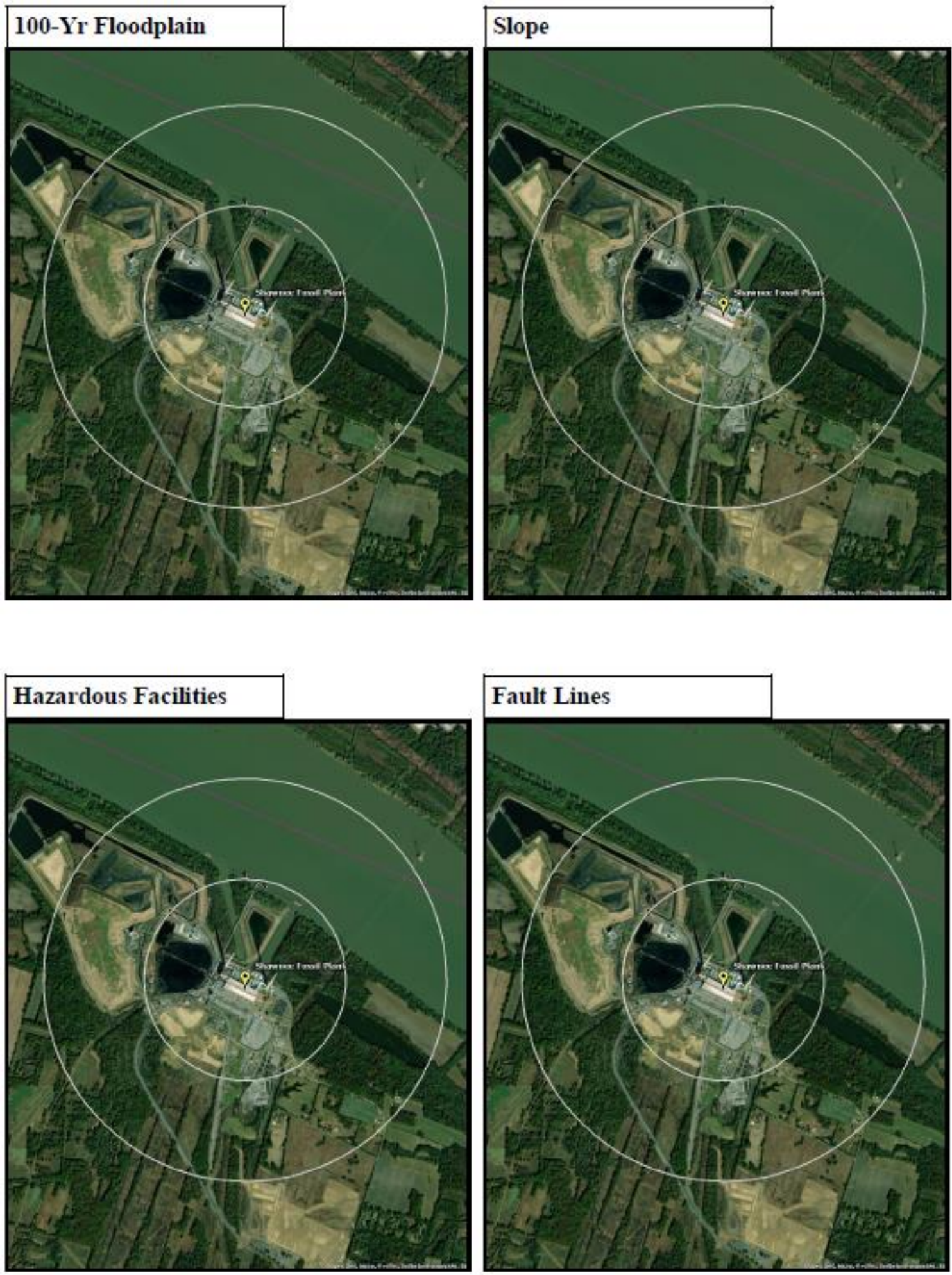

Figure 25. Shawnee Fossil Plant siting criteria maps showing 100-year flood plain, slope, hazardous facilities, and fault lines. 


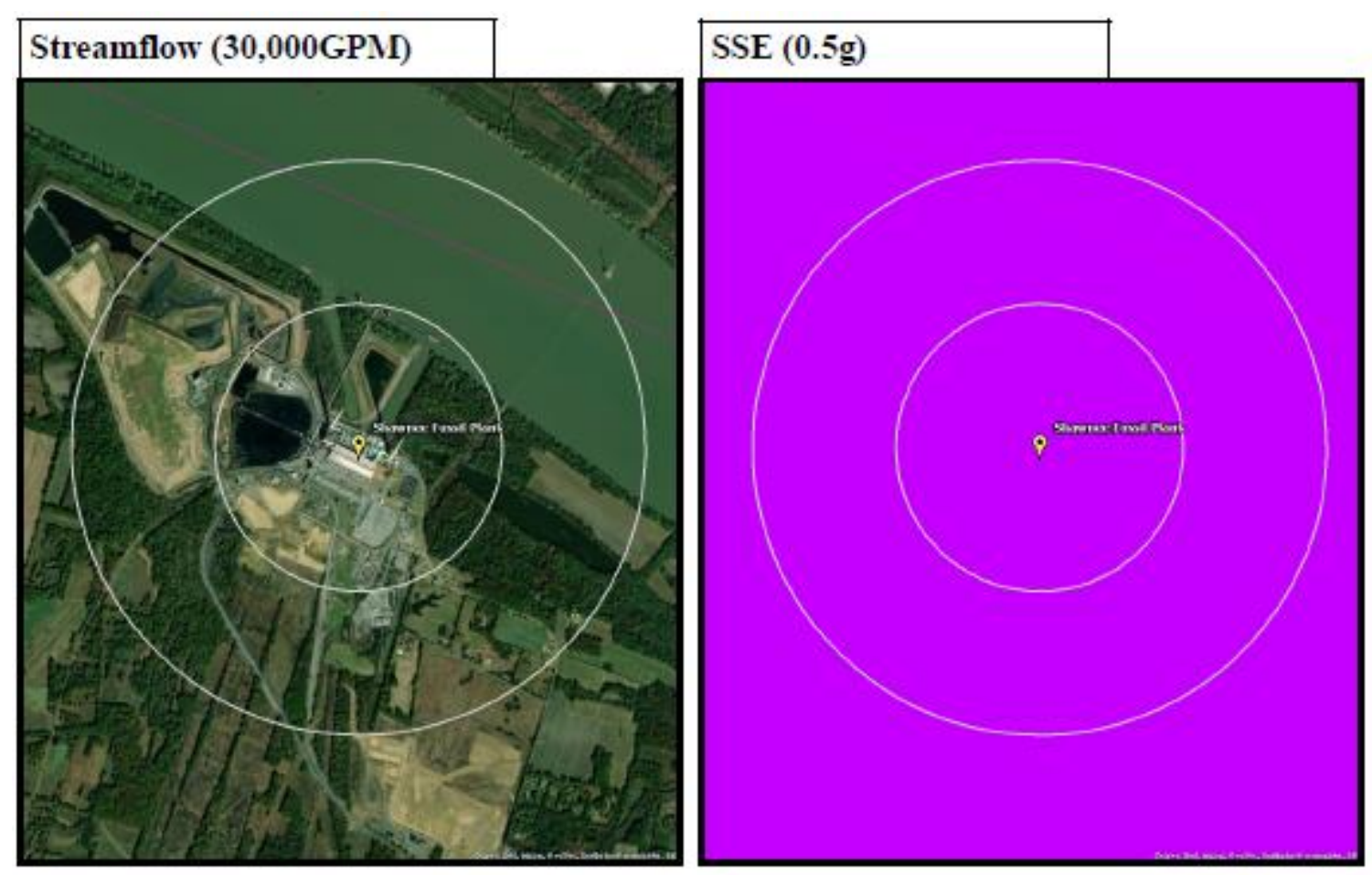

Figure 26. Shawnee Fossil Plant siting criteria maps showing streamflow and SSE.

\subsubsection{Summary}

The Shawnee Fossil Plant is about 7 miles west of the outskirts of Paducah, Kentucky, and 3 miles west of Metropolis, Illinois, across the Ohio River. There are no population density concerns for the Shawnee site in relation to utilization of SMR or advanced non-LWR technology with a small source term.

Although it is not shown as a hazard on the hazardous facilities criteria map, the Barkley Regional Airport is approximately 6 miles south of the Shawnee site. Neither runway is aligned with the plant site. Since the airport is classified as a general aviation airport, it does not require specific analysis per RG 4.7, and the runway alignment is not a concern. However, the proximity of the airport makes it prudent to gather and analyze data on flight frequency and typical plane size.

Open water around the borders of the site poses issues associated with a plant on a body of water. This is not an issue for the central portion of the site. The predominant risk to siting in this area is SSE because of the site's proximity to the New Madrid seismic zone. Engineering that would allow an advanced nonLWR to demonstrate public health and safety at peak ground acceleration (2\% chance in a 50-year return period) at values greater than $0.5 \mathrm{~g}$ will be necessary to propose siting in this region.

The area's seismic concerns place the Shawnee site at a lower priority candidate for consideration of an SMR or an advanced non-LWR. However, if technology allows for higher seismic conditions, then most of the yellow area shown in Figure 23 becomes suitable for consideration of SMR siting at Shawnee. 


\section{RETIRED TVA FOSSIL FUEL PLANTS}

The entry of the United States into World War II led to increasing power demand from various companies supporting the emerging war effort. In the TVA region, the aluminum industry required vast amounts of power to produce everything from helmets and identification tags to gas masks and airplanes. In addition, the experimental nuclear work and the Graphite Reactor operation in Oak Ridge, Tennessee (currently ORNL) required considerable energy [11].

Electric demand quickly outpaced the amount of power the original hydroelectric dams could produce, so TVA turned to coal-fired electric plants. TVA acquired the Wilson Steam Plant from the War Department and purchased power from other utility-owned coal-fired plants before it completed construction of the Watts Bar Steam Plant in 1942 [11].

Changing technology, increased environmental regulations, and economic factors have lessened the importance of coal in TVA's overall power generation portfolio. To date, 8 coal-fired plants have been closed, and more will close in the coming years as TVA's generation emphasis continues to shift toward cleaner sources of power [11].

The 8 plants evaluated in this section are listed below in their order of retirement, from 1966 until 2020:

- Wilson Steam Plant (1919-1966)

- Watts Bar Steam Plant (1942-1982)

- John Sevier Steam Plant (1955-2012)

- Widows Creek Fossil Plant (1952-2015)

- Colbert Fossil Plant (1951-2016)

- Johnsonville Fossil Plant (1949-2017)

- Allen Fossil Plant (1956-2018)

- Paradise Fossil Plant (1959-2020)

Dismantled infrastructure at older sites, as well as incorporation of alternative uses, may diminish the advantage and opportunity to consider siting an SMR or an advanced non-LWR at those locations. However, most of the retirements are more recent. 


\subsection{WILSON STEAM PLANT}

The Wilson Steam Plant was located on the south bank of the Tennessee River on the outskirts of Muscle Shoals, Alabama. The US Army Corps of Engineers began building Wilson Dam in 1918 to provide power to produce World War I munitions. Because the dam would take six years to complete, the Corps constructed the Wilson Steam Plant, which became operational in 1919. TVA acquired the steam and hydropower plants in 1933. The steam plant was retired in 1966 and was demolished in 1968. The land is now used for recreational purposes, including numerous hiking trails. The Wilson Hydroelectric plant is still in operation [11]. Aerial imagery of the plant's topography is shown in Figure 27.

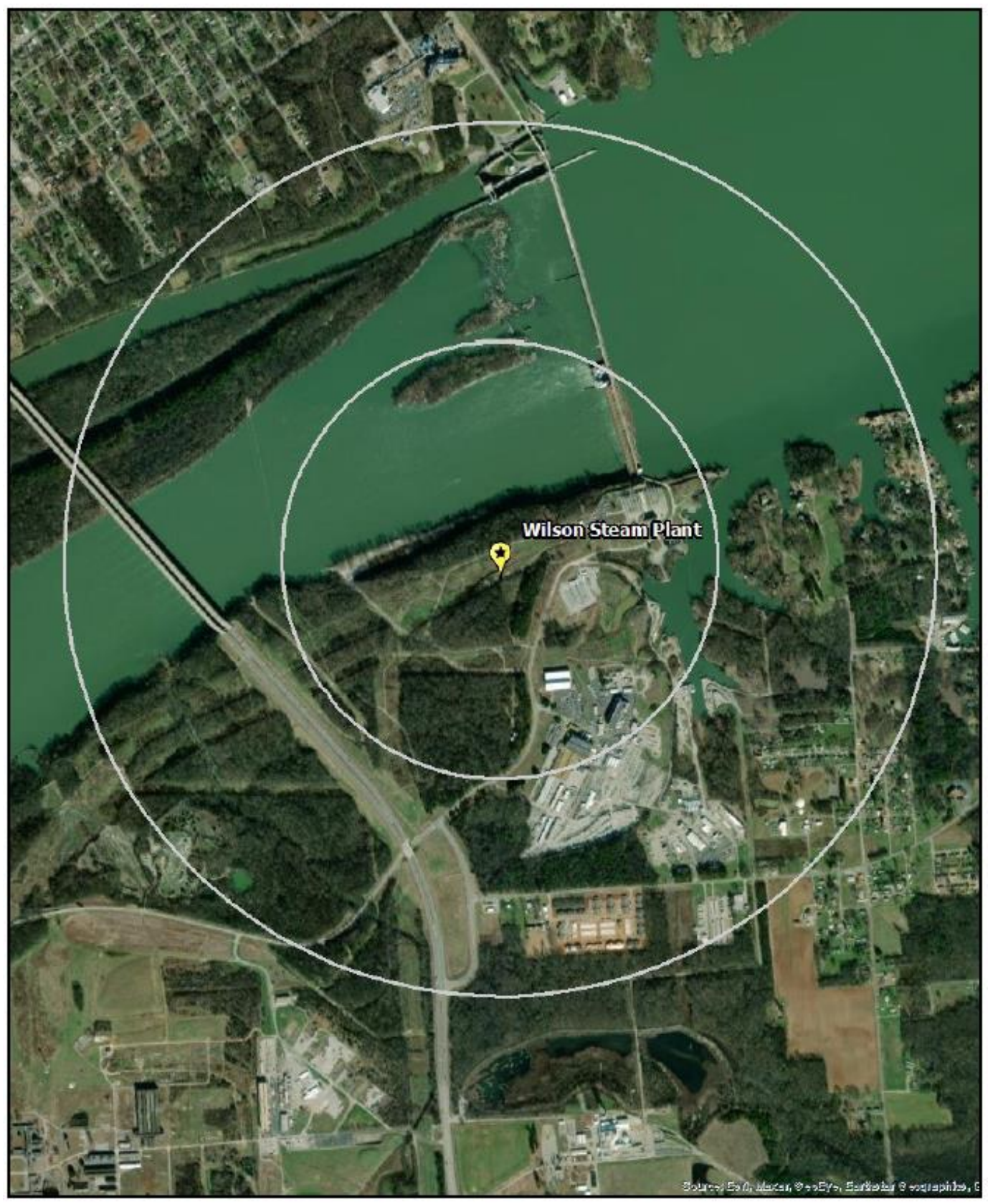

Figure 27. Satellite view of Wilson Steam Plant proximity. 


\section{Site Characterization: Composite Map}

\section{Site: Wilson Steam Plant}

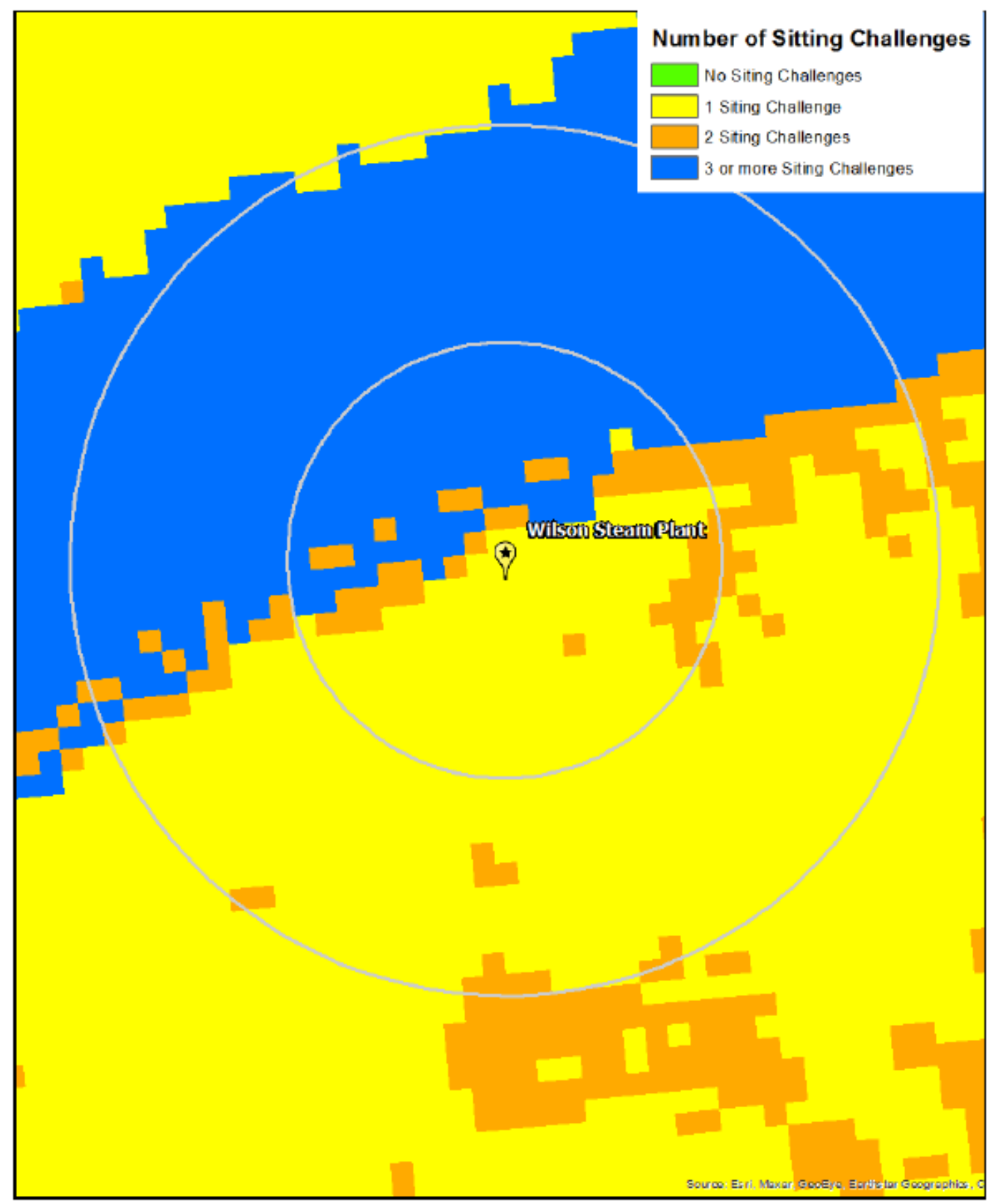

Figure 28. Wilson Steam Plant composite map.

\section{State: AL}



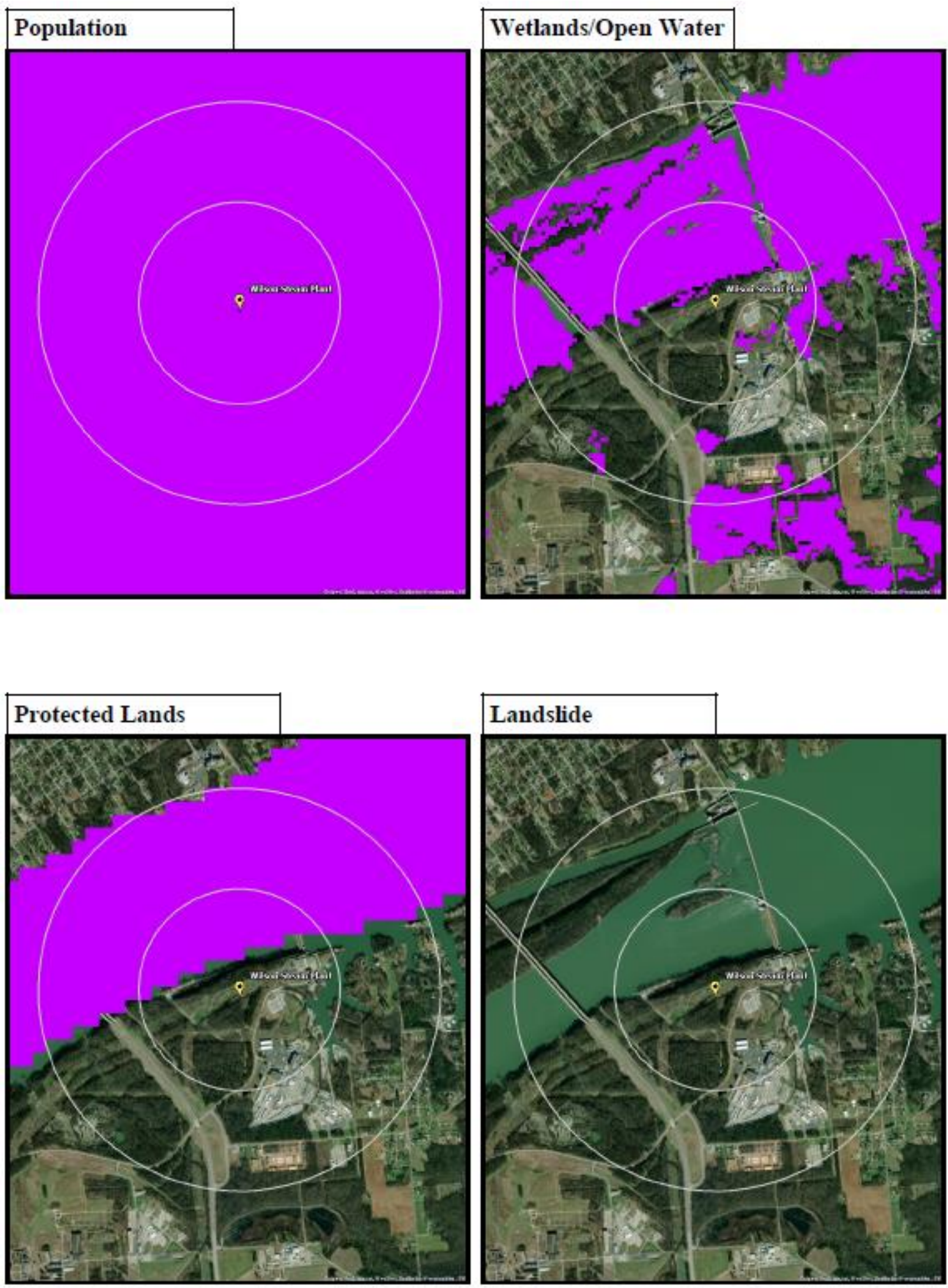

Figure 29. Wilson Steam Plant siting criteria maps showing population, wetlands/open water, protected lands, and landslide. 

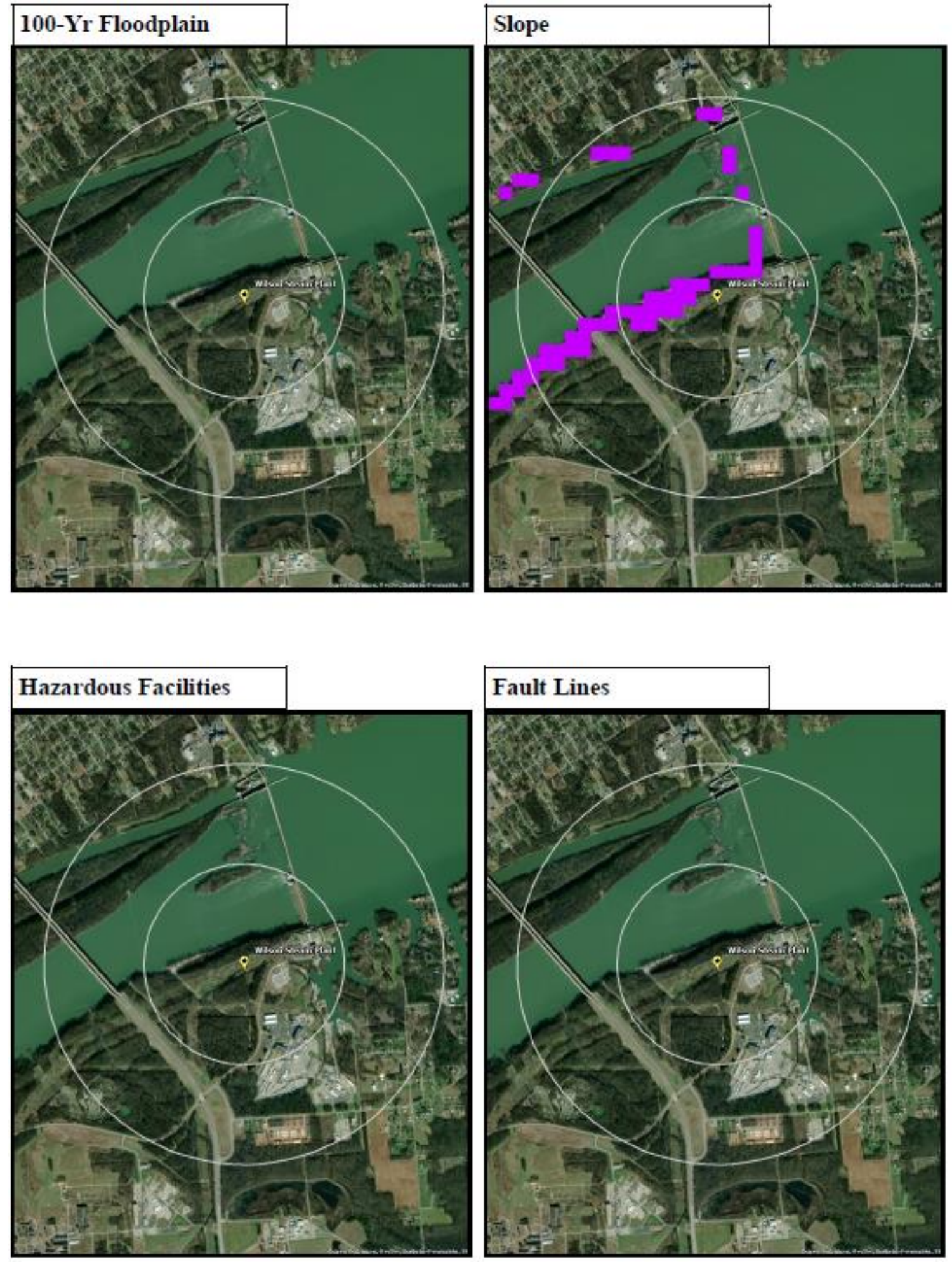

Figure 30. Wilson Steam Plant siting criteria maps showing 100-year floodplain, slope, hazardous facilities, and fault lines. 


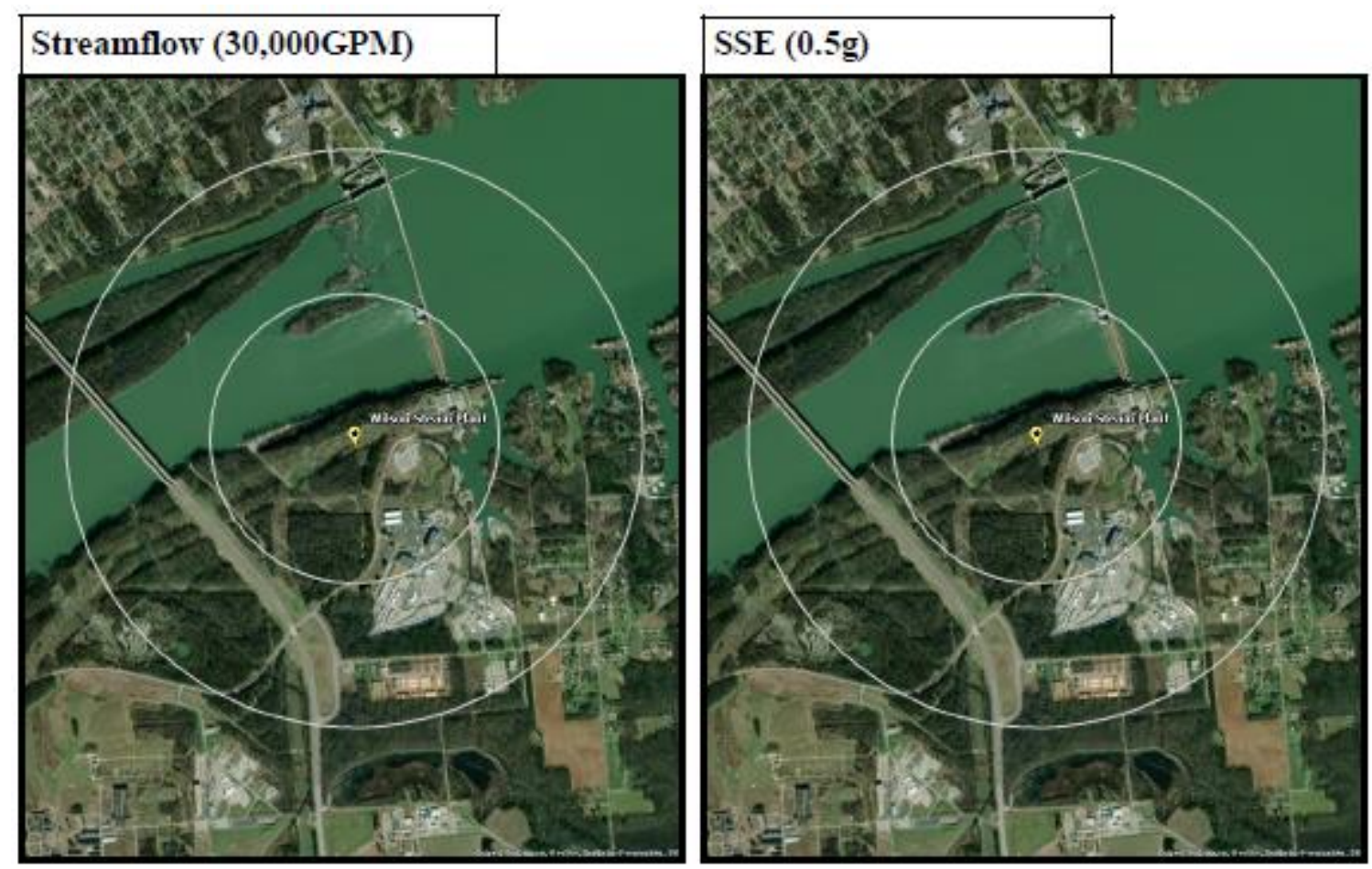

Figure 31. Wilson Steam Plant siting criteria maps showing streamflow and SSE.

\subsubsection{Summary}

The Wilson Steam Plant is on the immediate outskirts of Muscle Shoals, Alabama. Therefore, as shown in Figure 29, population density is an issue for the entire site, even with a proposed reduction in the calculation caps for siting an advanced non-LWR. The site is satisfactory in other respects. Only issues such as open water and slope show up as site factors, which are expected for a plant on a body of water. The river is also designated as protected.

The coal plant infrastructure has been demolished, but the hydroelectric plant still has its grid connection. Therefore, if the population consideration could be overcome, given that the population of Muscle Shoals is less than 25,000 residents, the site could be suitable for consideration of advanced non-LWR siting. However, with current recreational use of the site, this would be a difficult decision. 


\subsection{WATTS BAR STEAM PLANT}

The Watts Bar Steam Plant was located on 1,700 acres on the northern end of the Chickamauga Reservoir near Spring City, Tennessee. Construction on the four generating units was completed in 1942. The station had a combined summer net generating capacity of 267 megawatts. The steam plant was demolished in 2011. However, the site continues to be used for a hydroelectric plant and two large LWRs [11]. Aerial imagery of the plant's topography is shown in Figure 32.

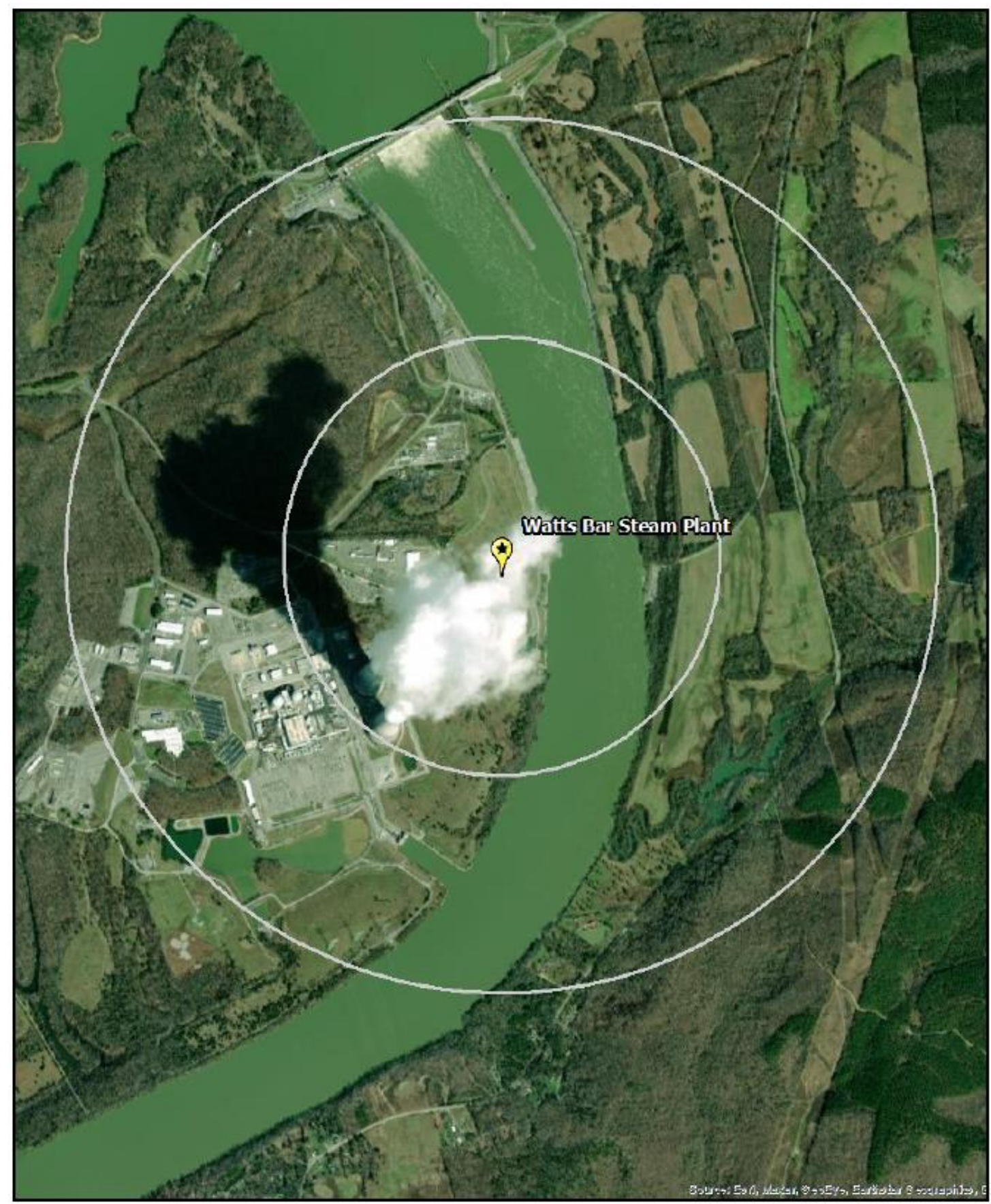

Figure 32. Satellite view of Watts Bar Steam Plant proximity. 


\subsubsection{Evaluation}

The screening results for the Watts Bar site are listed in Table 7, and a composite map for the surrounding area is shown in Figure 33. The physical plant structures are located on land, with no siting issues. Maps of the individual SMR siting criteria based on selected input values are also provided below.

Table 7. Watts Bar Steam Plant siting criteria summary

\begin{tabular}{|l|}
\hline SCleening Clitelia OVelview \\
\hline Site: Watts Bar Steam Plant $\quad$ State: TN \\
\hline
\end{tabular}

\begin{tabular}{|c|c|c|c|c|c|c|}
\hline \multicolumn{2}{|c|}{ No Siting Issue } & \multicolumn{2}{|l|}{ Partial Siting Issue } & \multicolumn{3}{|c|}{ Full Siting Issue } \\
\hline $\begin{array}{c}\text { Inside } \\
\text { the } 0.5 \\
\text { mile } \\
\text { Radius } \\
\end{array}$ & $\begin{array}{c}\text { Pop } \\
\text { Density }\end{array}$ & 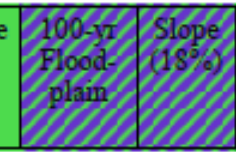 & \begin{tabular}{|c|} 
Hazardous \\
Facilities \\
\end{tabular} & $\begin{array}{l}\text { Fault } \\
\text { Lines }\end{array}$ & 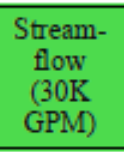 & $\begin{array}{l}\text { SSE } \\
(0.5 \mathrm{~g})\end{array}$ \\
\hline $\begin{array}{l}\text { Inside } \\
\text { the } \\
0.6 \text { to } 1- \\
\text { mile } \\
\text { Radius }\end{array}$ & $\begin{array}{c}\text { Pop } \\
\text { Density }\end{array}$ & 7y) & \begin{tabular}{|c|} 
Hazardous \\
Facilities
\end{tabular} & $\begin{array}{l}\text { Fault } \\
\text { Lines }\end{array}$ & $\begin{array}{l}\text { Stream- } \\
\text { flow } \\
(30 \mathrm{~K} \\
\text { GPM) }\end{array}$ & $\begin{array}{l}\text { SSE } \\
(0.5 \mathrm{~g})\end{array}$ \\
\hline & & & & Va & & \\
\hline Population & Density withi & & $>5$ & (peopl & quare mile) & \\
\hline Wetlands & ind Open wate: & & & & & \\
\hline Protected & ands are exclu & & & & & \\
\hline Land with & moderate/high & ility are excluded & & & & \\
\hline Land that & ies within a 10 & & & & & \\
\hline Slope & & & & $>18 \%$ & $\left.10^{\circ}\right)$ & \\
\hline $\begin{array}{l}\text { Land loca } \\
\text { (Airport - }\end{array}$ & $\begin{array}{l}\text { ed in proximity } \\
5 \mathrm{mi} \text {; Oil Refin }\end{array}$ & ases-1 mi) & & & & \\
\hline Land too $c$ & lose to identifi & & & & & \\
\hline Streamflor & $\mathrm{v}$ within $20 \mathrm{mi}$ & & & $\geq 30,0$ & gpm & \\
\hline Safe-shutc & own earthquak & & & & & \\
\hline
\end{tabular}




\section{Site Characterization: Composite Map}

Site: Watts Bar Steam Plant

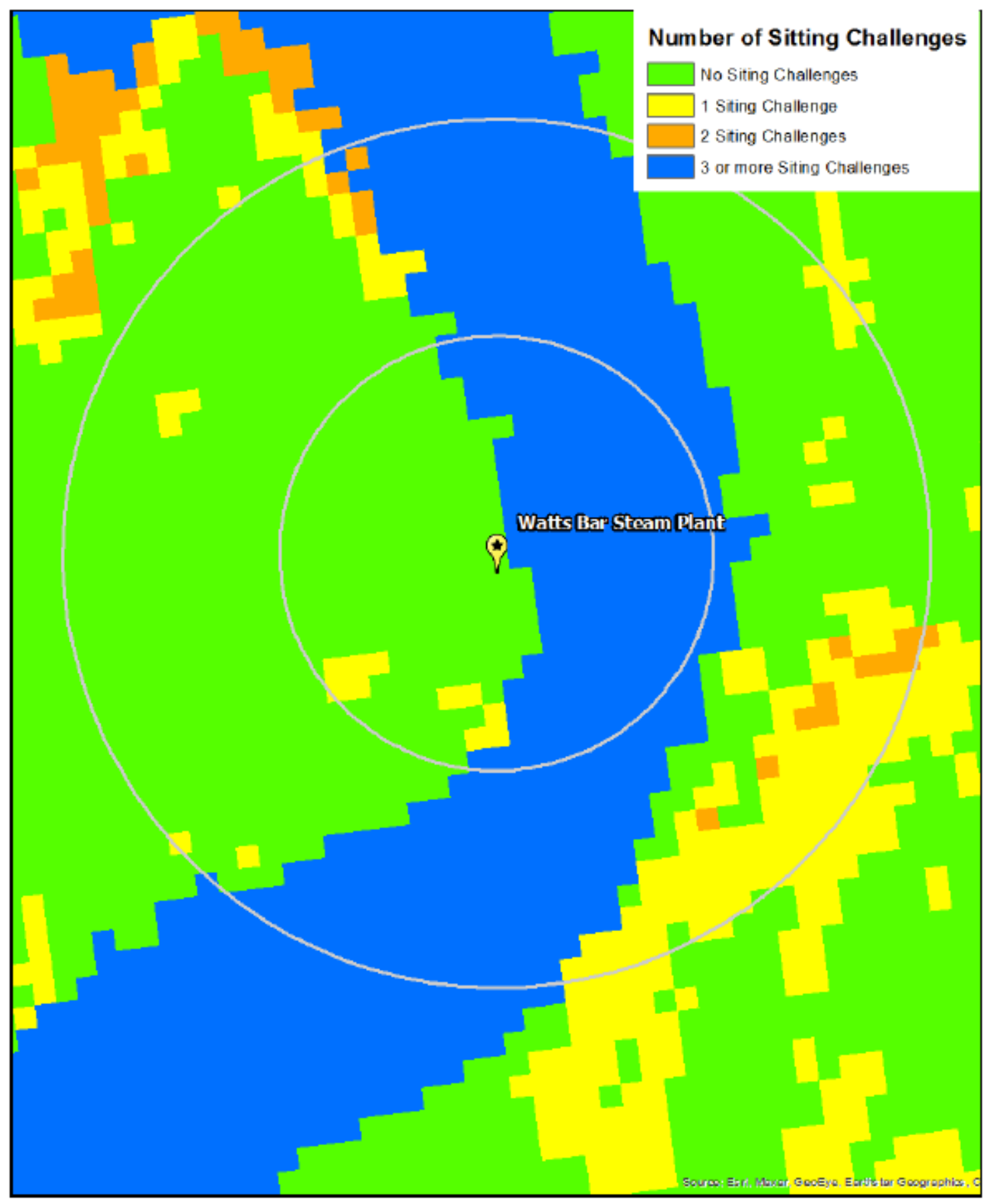

Figure 33. Watts Bar Steam Plant composite map.

State: TN 

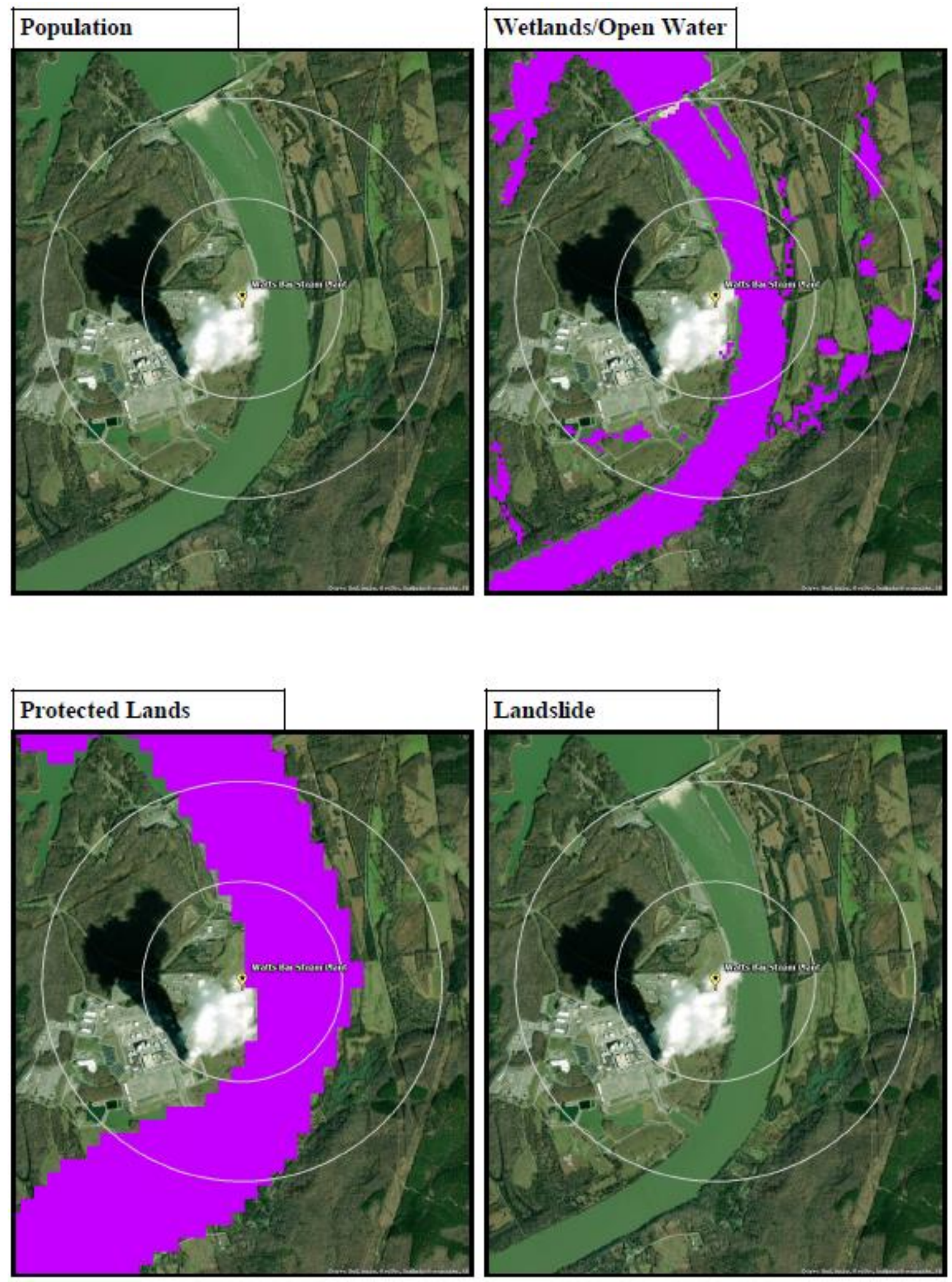

Figure 34. Watts Bar Steam Plant siting criteria maps showing population, wetlands/open water, protected lands, and landslide. 

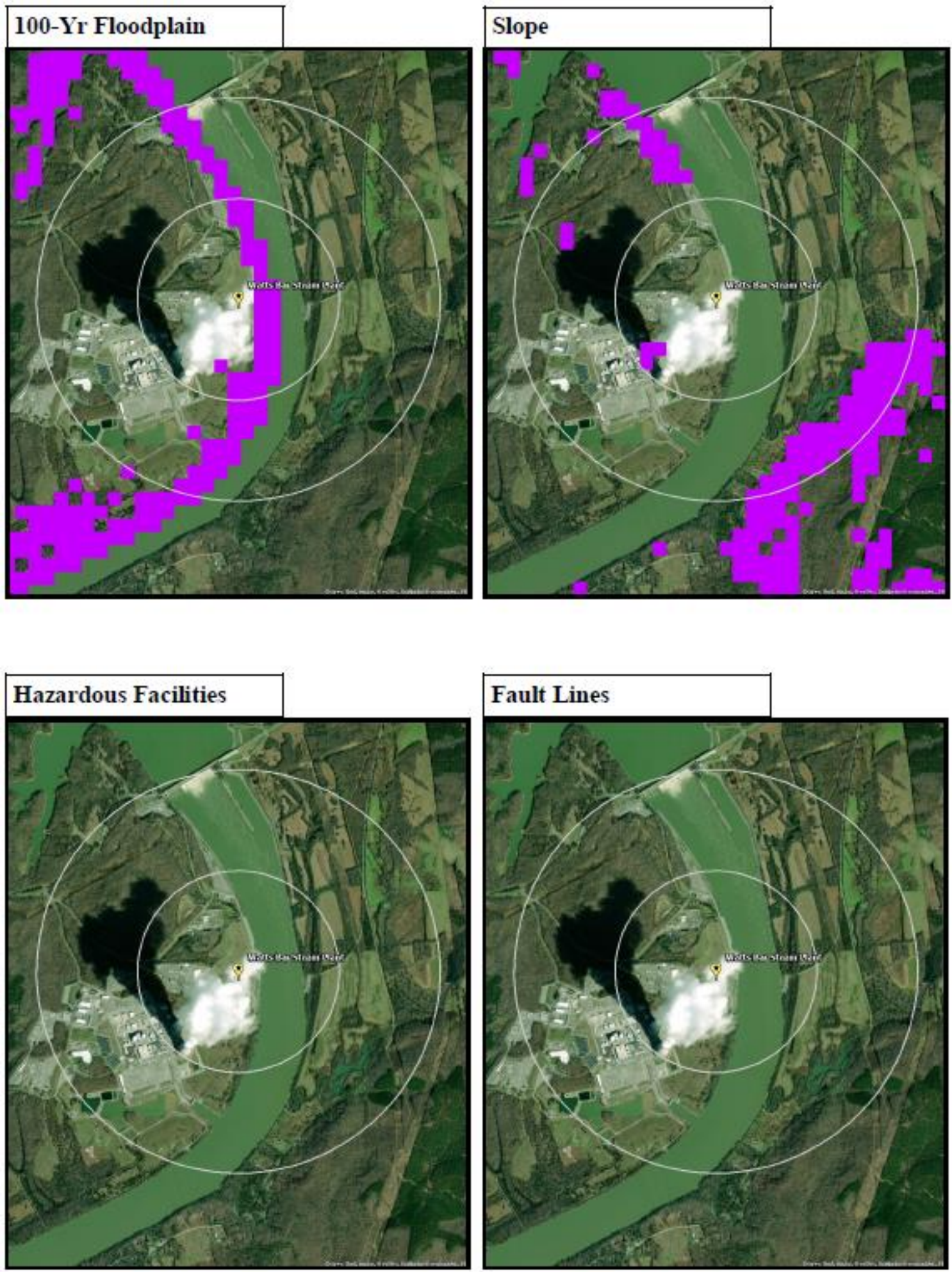

Figure 35. Watts Bar Steam Plant siting criteria maps showing 100-year floodplain, slope, hazardous facilities, and fault lines. 

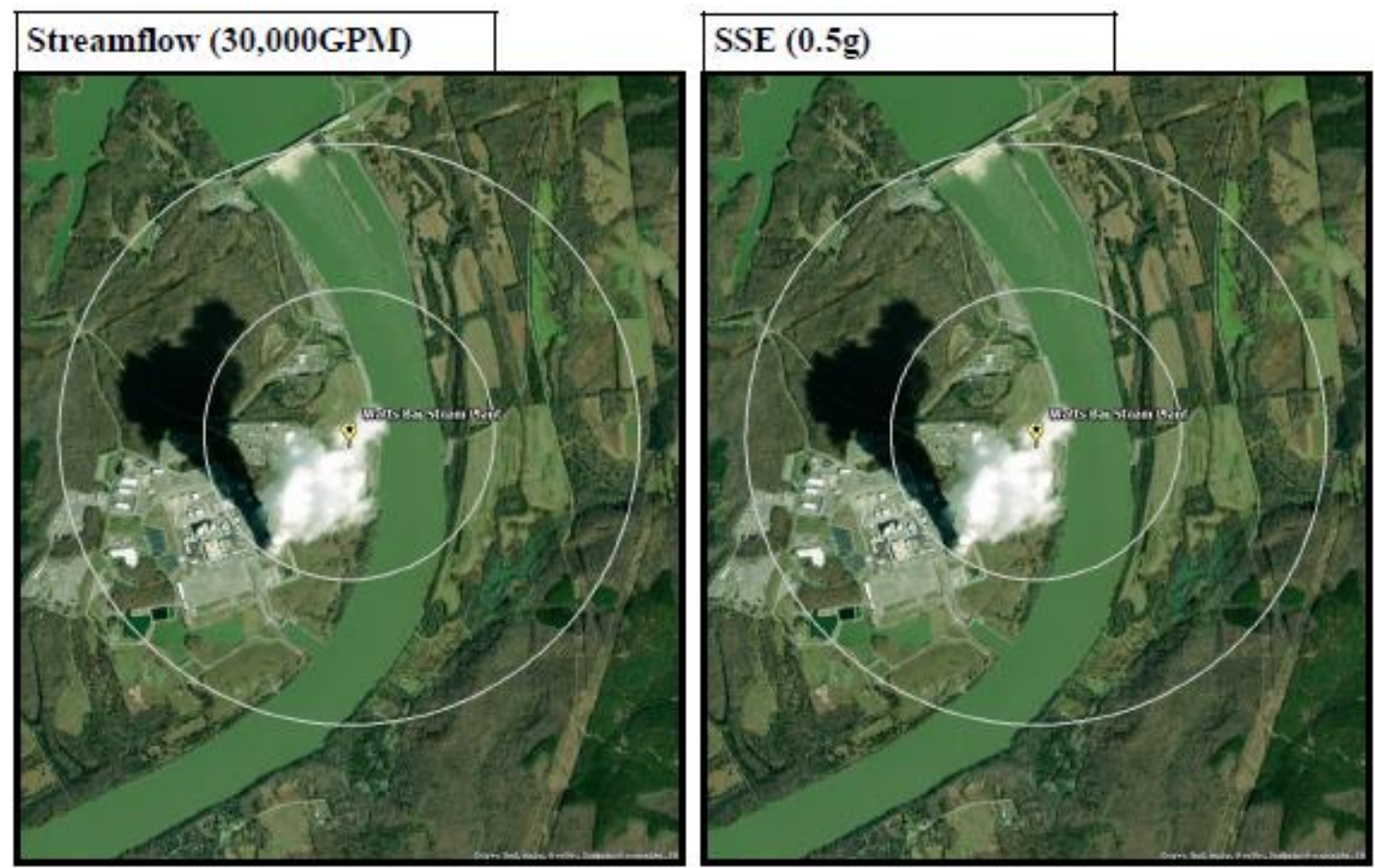

Figure 36. Watts Bar Steam Plant siting criteria maps showing streamflow and SSE.

\subsubsection{Summary}

The only visual issues associated with this site are related to open water, slope, and floodplain, all of which are typically associated with a plant on a body of water. The waterway itself is also designated as protected. However, the central Watts Bar site meets all the SMR and advanced non-LWR siting parameters, and the site currently hosts two large LWRs. The site could easily be considered for additional capacity, even though the steam plant infrastructure has been demolished. 


\subsection{JOHN SEVIER STEAM PLANT}

The John Sevier Steam Plant was located on 750 acres on the south bank of the Holston River near Rogersville, Tennessee. Construction on the four generating units was completed between 1955 and 1957. The station had a combined summer net generating capacity of 704 megawatts. The steam plant was decommissioned in 2012 and demolished between 2015 and 2017. In its place, TVA built an 880 MW combined cycle gas plant which came online in 2012. TVA currently plans to sell the excess land for industrial or commercial purposes [11]. Aerial imagery of the plant's topography is shown in Figure 37. The structures shown in the figure are associated with the combined cycle plant.

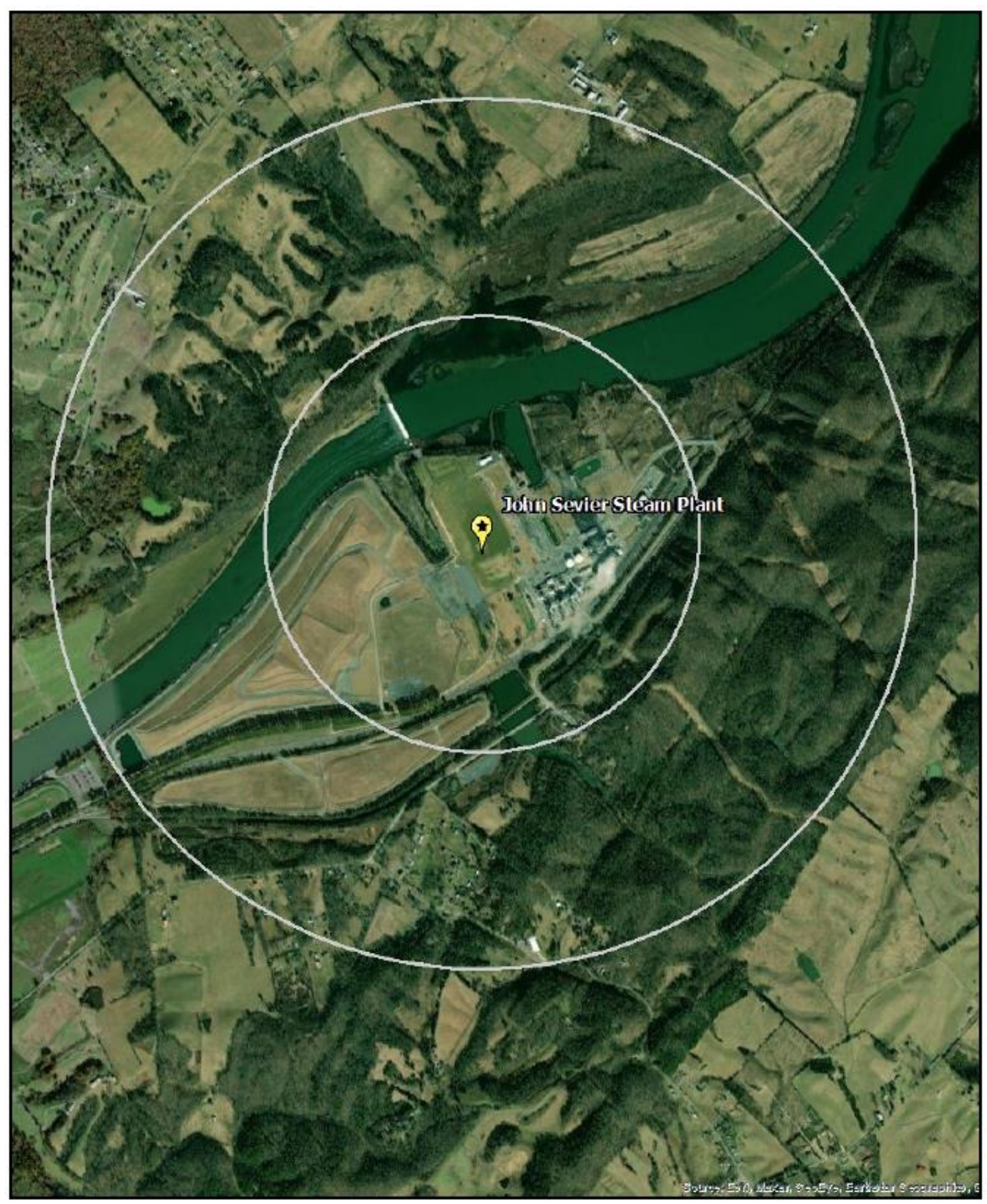

Figure 37. Satellite view of John Sevier Steam Plant proximity. 


\subsubsection{Evaluation}

The screening results for the John Sevier site are listed in Table 8, and a composite map for the surrounding area is shown in Figure 38. The physical plant structures are located on land, with no siting issues. Maps of the individual SMR siting criteria based on selected input values are also provided below.

Table 8. John Sevier Steam Plant siting criteria summary

\section{Screening Criteria Overview}

Site: John Sevier Steam Plant

State: TN

\begin{tabular}{|c|c|c|c|c|c|c|}
\hline \multicolumn{7}{|c|}{ Screening Criteria Summary Bar } \\
\hline \multicolumn{2}{|c|}{ No Siting Issue } & Partial Siting Issue & & \multicolumn{3}{|c|}{\begin{tabular}{|l|l|} 
& Full Siting Issue \\
\end{tabular}} \\
\hline $\begin{array}{c}\text { Inside } \\
\text { the } 0.5 \\
\text { mile } \\
\text { Radius } \\
\end{array}$ & $\begin{array}{c}\text { Pop } \\
\text { Density } \\
\text { Lands } \\
\end{array}$ & 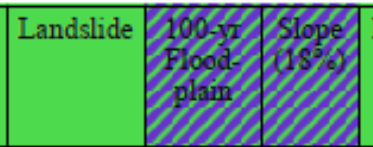 & \begin{tabular}{c|} 
Hazardous \\
Facilities
\end{tabular} & $\begin{array}{l}\text { Fault } \\
\text { Lines }\end{array}$ & \begin{tabular}{l|} 
Stream- \\
flow \\
(30K \\
GPM) \\
\end{tabular} & $\begin{array}{l}\text { SSE } \\
(0.5 \mathrm{~g})\end{array}$ \\
\hline \begin{tabular}{|l|} 
Inside \\
the \\
0.6 to $1-$ \\
mile \\
Radius
\end{tabular} & \begin{tabular}{|c|c|} 
Pop & $\begin{array}{c}\text { Protected } \\
\text { Lensity }\end{array}$ \\
& \\
\end{tabular} & 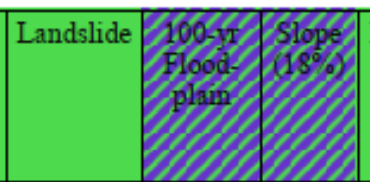 & \begin{tabular}{c|} 
Hazardous \\
Facilities
\end{tabular} & $\begin{array}{l}\text { Fault } \\
\text { Lines }\end{array}$ & \begin{tabular}{l|} 
Stream- \\
flow \\
$(30 \mathrm{~K}$ \\
GPM)
\end{tabular} & $\begin{array}{c}\mathrm{SSE} \\
(0.5 \mathrm{~g})\end{array}$ \\
\hline \multicolumn{7}{|c|}{ Screening Criteria Table } \\
\hline \multicolumn{3}{|c|}{ Criteria } & \multicolumn{4}{|c|}{ Value } \\
\hline \multicolumn{3}{|c|}{ Population Density within 4 miles } & \multicolumn{4}{|c|}{$>500$ (people/square mile) } \\
\hline \multicolumn{3}{|c|}{ Wetlands and Open water are excluded } & \multicolumn{4}{|c|}{-} \\
\hline \multicolumn{3}{|c|}{ Protected lands are excluded } & \multicolumn{4}{|c|}{-} \\
\hline \multicolumn{3}{|c|}{ Land with moderate/high landslide hazard susceptibility are excluded } & \multicolumn{4}{|c|}{-} \\
\hline \multicolumn{3}{|c|}{ Land that lies within a 100 -year floodplain is excluded } & \multicolumn{4}{|c|}{-} \\
\hline \multicolumn{3}{|l|}{ Slope } & \multicolumn{4}{|c|}{$>18 \%\left(\sim 10^{\circ}\right)$} \\
\hline \multicolumn{3}{|c|}{$\begin{array}{l}\text { Land located in proximity to hazardous facilities } \\
\text { (Airport - 5mi; Oil Refineries - } 1 \mathrm{mi} \text {; and Military Bases }-1 \mathrm{mi} \text { ) }\end{array}$} & \multicolumn{4}{|c|}{-} \\
\hline \multicolumn{3}{|c|}{ Land too close to identified fault lines is avoided } & \multicolumn{4}{|c|}{-} \\
\hline \multicolumn{3}{|c|}{ Streamflow within 20 miles } & \multicolumn{4}{|c|}{$\geq 30,000 \mathrm{gpm}$} \\
\hline \multicolumn{3}{|c|}{ Safe-shutdown earthquake peak ground acceleration } & \multicolumn{4}{|c|}{$\geq 0.5 \mathrm{~g}$} \\
\hline
\end{tabular}




\section{Site Characterization: Composite Map \\ Site: John Sevier Steam Plant \\ State: TN}

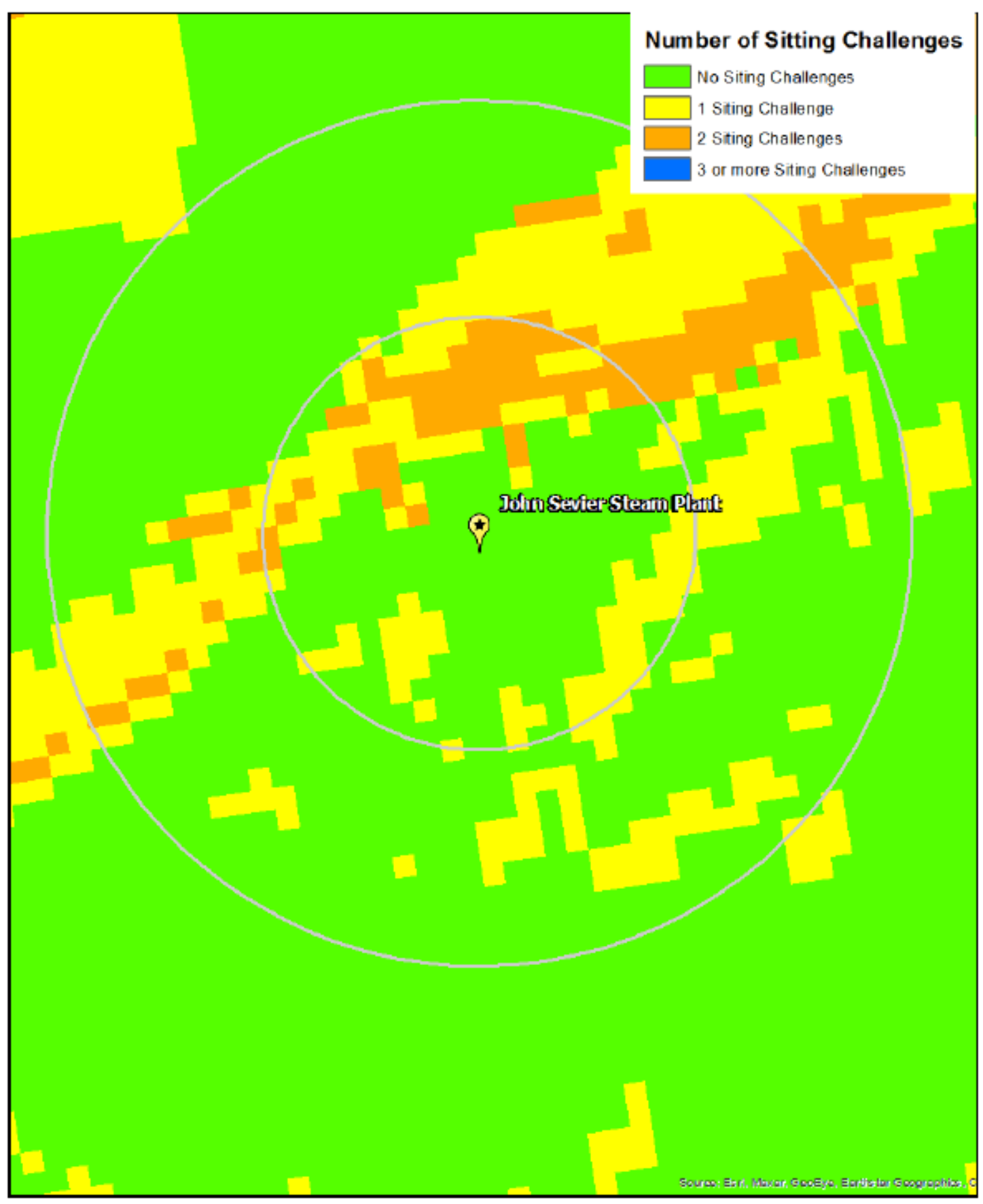

Figure 38. John Sevier Steam Plant composite map. 

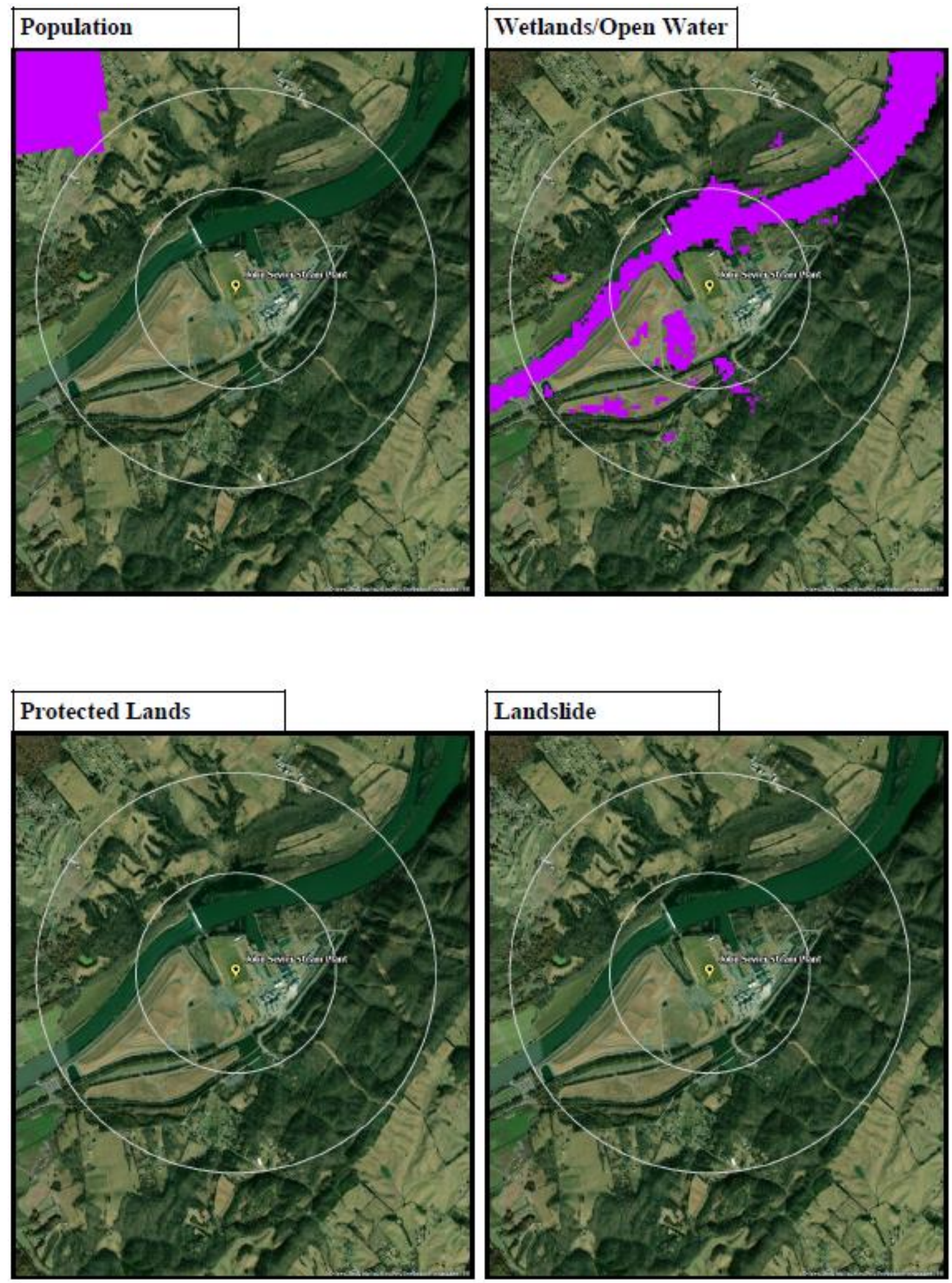

Figure 39. John Sevier Steam Plant siting criteria maps showing population, wetlands/open water, protected lands, and landslide. 

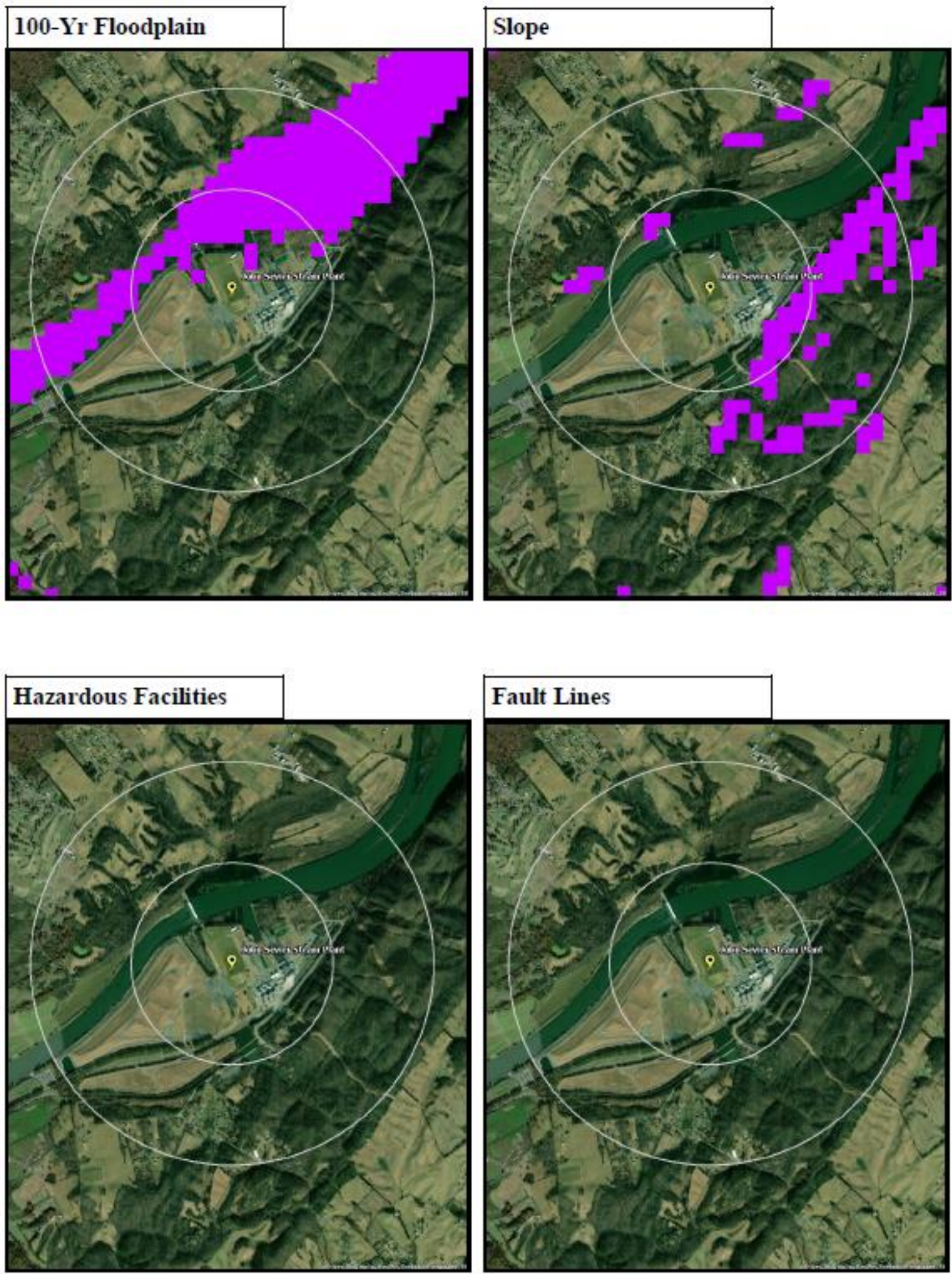

Figure 40. John Sevier Steam Plant siting criteria maps showing 100-year floodplain, slope, hazardous facilities, and fault lines. 


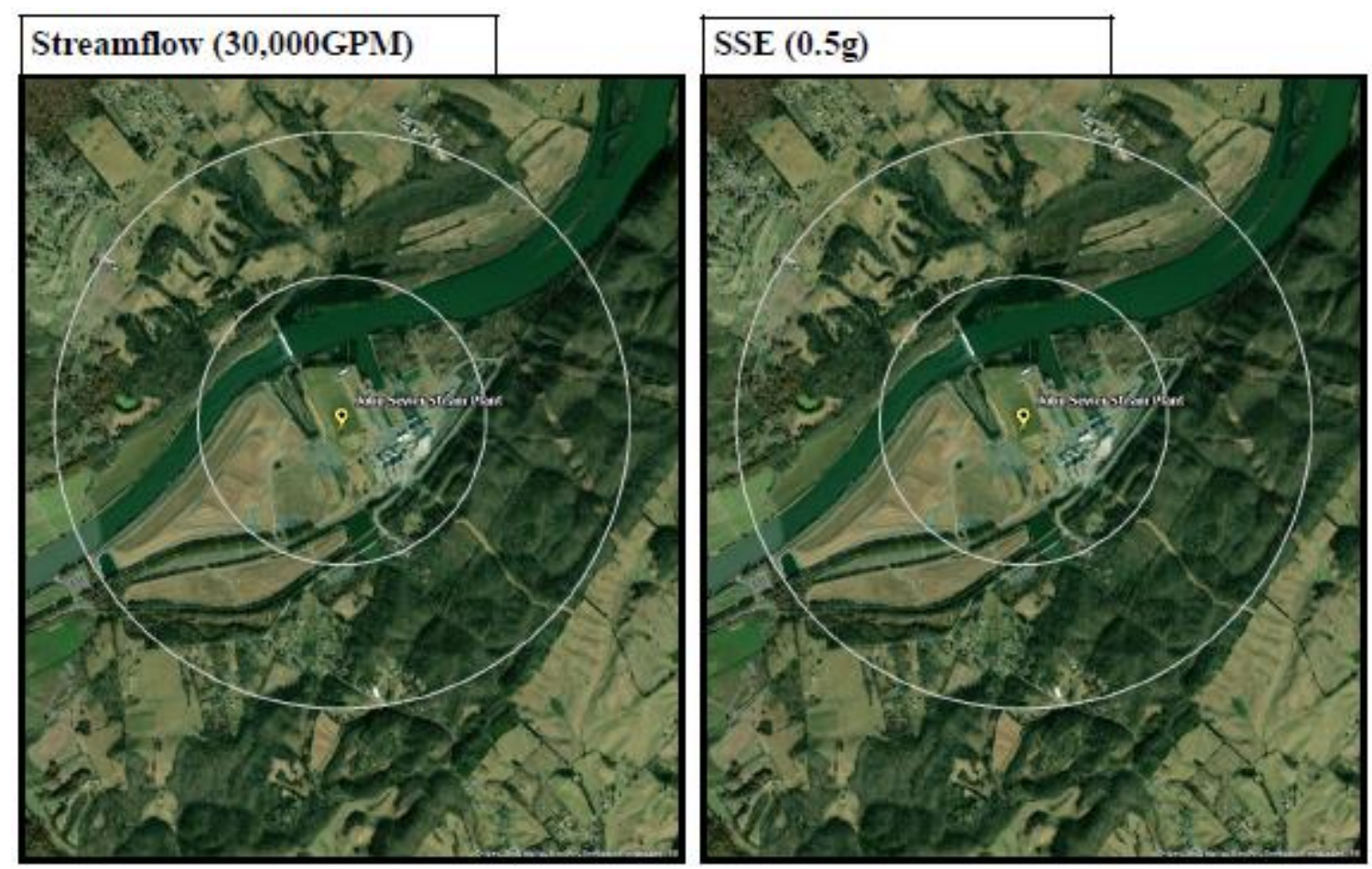

Figure 41. John Sevier Steam Plant siting criteria maps showing streamflow and SSE.

\subsubsection{Summary}

The only visual issues associated with this site are related to open water, slope, and floodplain, all of which are typically associated with a plant along a major waterway.

The John Sevier Fossil Plant is about 3 miles southeast of Rogersville, Tennessee, as indicated by the small population flag in the northwest corner of the population site map above. However, there are no population density concerns for the central John Sevier site in relation to utilization of SMR or advanced non-LWR technology with a small source term associated with Rogersville.

As shown in Figure 38, the John Sevier site is suitable for siting an SMR or an advanced non-LWR if supported by future regional load demand and if TVA retains the excess site land formerly associated with the demolished coal plant. 


\subsection{WIDOWS CREEK FOSSIL PLANT}

The Widows Creek Fossil Plant was located on approximately 950 acres on the Tennessee River near Stevenson, Alabama. Eight generating units were completed between 1952 and 1965. The station had a combined summer net generating capacity of 1,800 megawatts. The steam plant units were decommissioned between 2012 and 2015, and demolition is in progress, with completion expected in 2021. Google plans to build a datacenter on the sites of units 1-6 [11]. Aerial imagery of the plant's topography is shown in Figure 42.

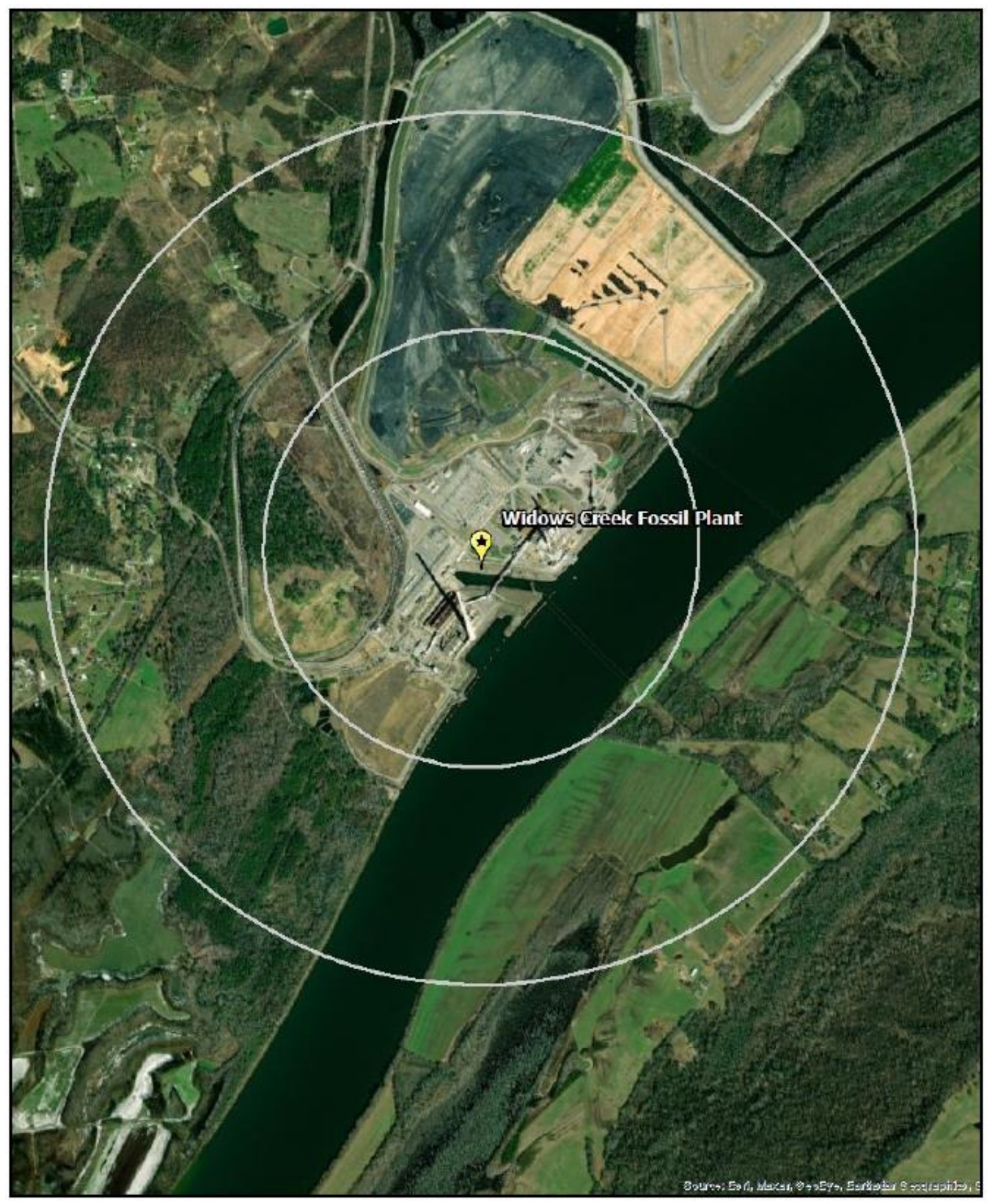

Figure 42. Satellite view of Widows Creek Fossil Plant proximity. 


\subsubsection{Evaluation}

The screening results for the Widows Creek site are listed in Table 9, and a composite map for the surrounding area is shown in Figure 43. The physical plant structures are located on land, with no siting issues. Maps of the individual SMR siting criteria based on selected input values are also included below.

Table 9. Widows Creek Fossil Plant siting criteria summary

\begin{tabular}{|lc|}
\hline \multicolumn{2}{|c|}{ Screening Criteria Overview } \\
\hline Site: Widows Creek Fossil Plant & State: AL \\
\hline
\end{tabular}

\begin{tabular}{|c|c|c|c|c|c|c|c|c|c|}
\hline \multicolumn{10}{|c|}{$\underset{\text { (Colored Boxes indicate Screening Results) }}{\text { Screening Criteria Summary }}$} \\
\hline \multicolumn{3}{|c|}{ No Siting Issue } & \multicolumn{3}{|r|}{ Partial Siting Issue } & \multicolumn{4}{|c|}{ Full Siting Issue } \\
\hline $\begin{array}{c}\text { Inside } \\
\text { the } 0.5 \\
\text { mile } \\
\text { Radius } \\
\end{array}$ & \begin{tabular}{|c|} 
Pop \\
Density
\end{tabular} & $\begin{array}{l}\text { Wet- } \\
\text { lands }\end{array}$ & \begin{tabular}{c|} 
Protected \\
Lands
\end{tabular} & Landslide & \begin{tabular}{|c|c|}
$100-\mathrm{yr}$ & Slope \\
Flood- & $(18 \%)$ \\
plain & \\
\end{tabular} & \begin{tabular}{|c|} 
Hazardous \\
Facilities
\end{tabular} & $\begin{array}{l}\text { Fault } \\
\text { Lines }\end{array}$ & 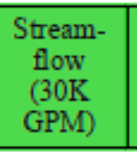 & $\begin{array}{l}\text { SSE } \\
(0.5 \mathrm{~g})\end{array}$ \\
\hline \begin{tabular}{|c|} 
Inside \\
the \\
0.6 to $1-$ \\
mile \\
Radius \\
\end{tabular} & \begin{tabular}{|c|} 
Pop \\
Density \\
\end{tabular} & $\begin{array}{l}\text { Wet- } \\
\text { lands }\end{array}$ & $\begin{array}{c}\text { Protected } \\
\text { Lands }\end{array}$ & Landslide & \begin{tabular}{|l|l|}
$100-\mathrm{y}$ & Slope \\
Flood- & $(18 \%)$ \\
plain
\end{tabular} & \begin{tabular}{|c|} 
Hazardous \\
Facilities
\end{tabular} & $\begin{array}{l}\text { Fault } \\
\text { Lines }\end{array}$ & $\begin{array}{l}\text { Stream- } \\
\text { flow } \\
(30 \mathrm{~K} \\
\text { GPM) }\end{array}$ & $\begin{array}{c}\mathrm{SSE} \\
(0.5 \mathrm{~g})\end{array}$ \\
\hline \multicolumn{10}{|c|}{ Screening Criteria Table } \\
\hline \multicolumn{6}{|c|}{ Criteria } & \multicolumn{4}{|c|}{ Value } \\
\hline \multicolumn{6}{|c|}{ Population Density within 4 miles } & \multicolumn{4}{|c|}{$>500$ (people/square mile) } \\
\hline \multicolumn{6}{|c|}{ Wetlands and Open water are excluded } & \multicolumn{4}{|c|}{-} \\
\hline \multicolumn{6}{|c|}{ Protected lands are excluded } & \multicolumn{4}{|c|}{-} \\
\hline \multicolumn{6}{|c|}{ Land with moderate/high landslide hazard susceptibility are excluded } & \multicolumn{4}{|c|}{-} \\
\hline \multicolumn{6}{|c|}{ Land that lies within a 100 -year floodplain is excluded } & \multicolumn{4}{|c|}{ - } \\
\hline \multicolumn{6}{|l|}{ Slope } & \multicolumn{4}{|c|}{$>18 \%\left(\sim 10^{\circ}\right)$} \\
\hline \multicolumn{6}{|c|}{$\begin{array}{l}\text { Land located in proximity to hazardous facilities } \\
\text { (Airport - } 5 \mathrm{mi} \text {; Oil Refineries - } 1 \mathrm{mi} \text {; and Military Bases-1 mi) }\end{array}$} & \multicolumn{4}{|c|}{-} \\
\hline \multicolumn{6}{|c|}{ Land too close to identified fault lines is avoided } & \multicolumn{4}{|c|}{-} \\
\hline \multicolumn{6}{|c|}{ Streamflow within 20 miles } & \multicolumn{4}{|c|}{$\geq 30,000 \mathrm{gpm}$} \\
\hline \multicolumn{6}{|c|}{ Safe-shutdown earthquake peak ground acceleration } & \multicolumn{4}{|c|}{$\geq 0.5 \mathrm{~g}$} \\
\hline
\end{tabular}




\section{Site Characterization: Composite Map}

Site: Widows Creek Fossil Plant State: AL

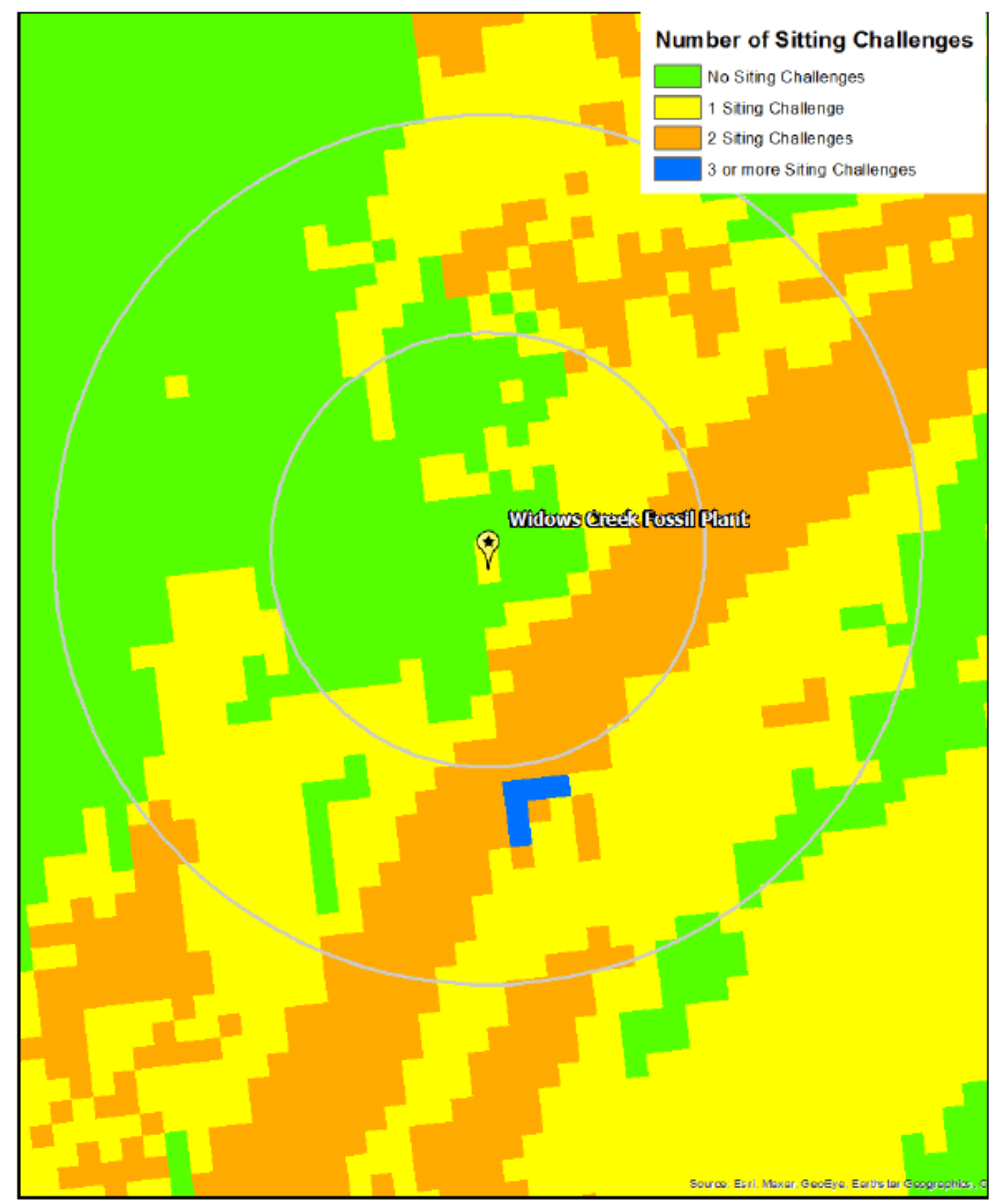

Figure 43. Widows Creek Fossil Plant composite map. 

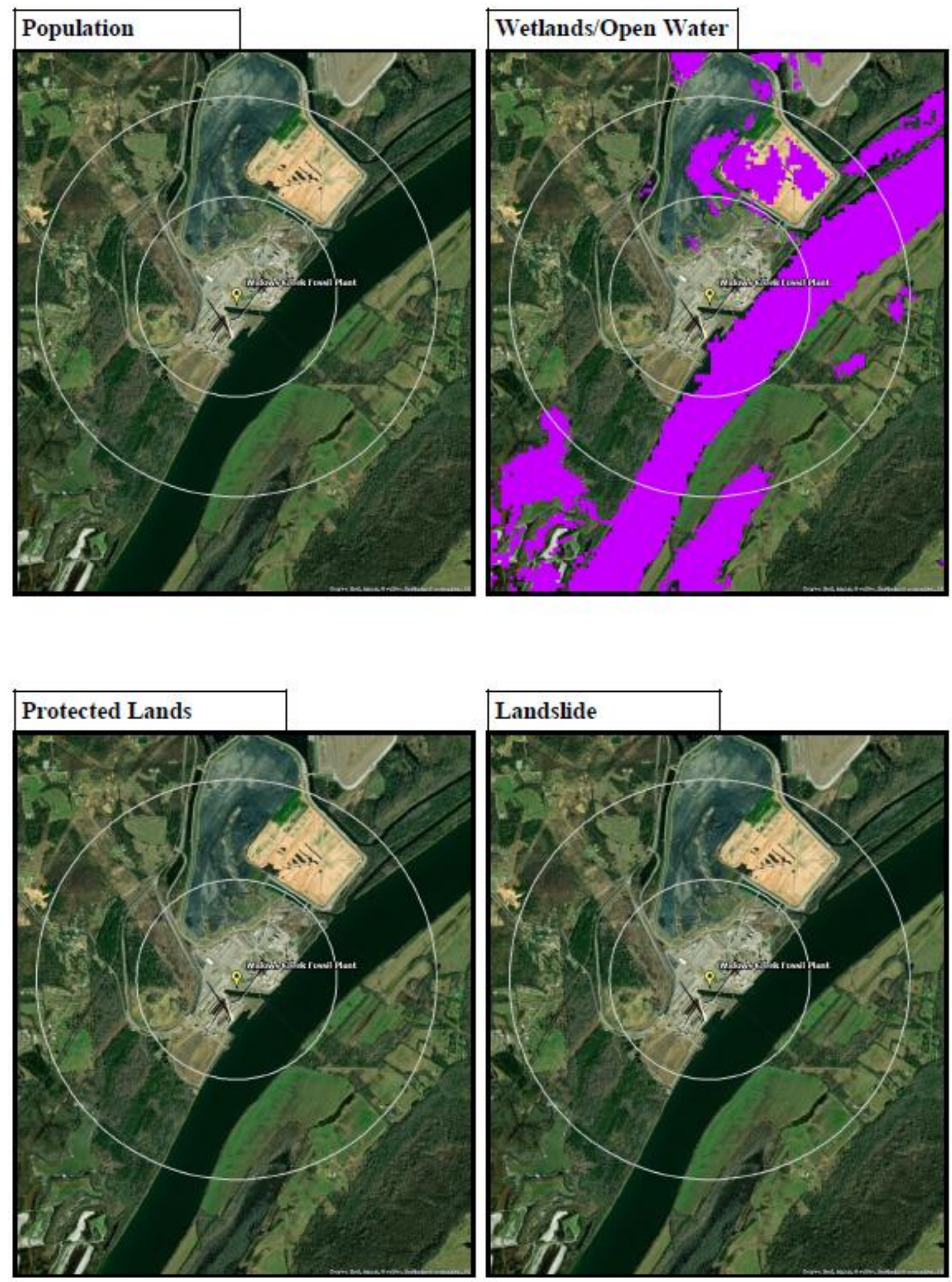

Figure 44. Widows Creek Fossil Plant siting criteria maps showing population, wetlands/open water, protected lands, and landslide. 

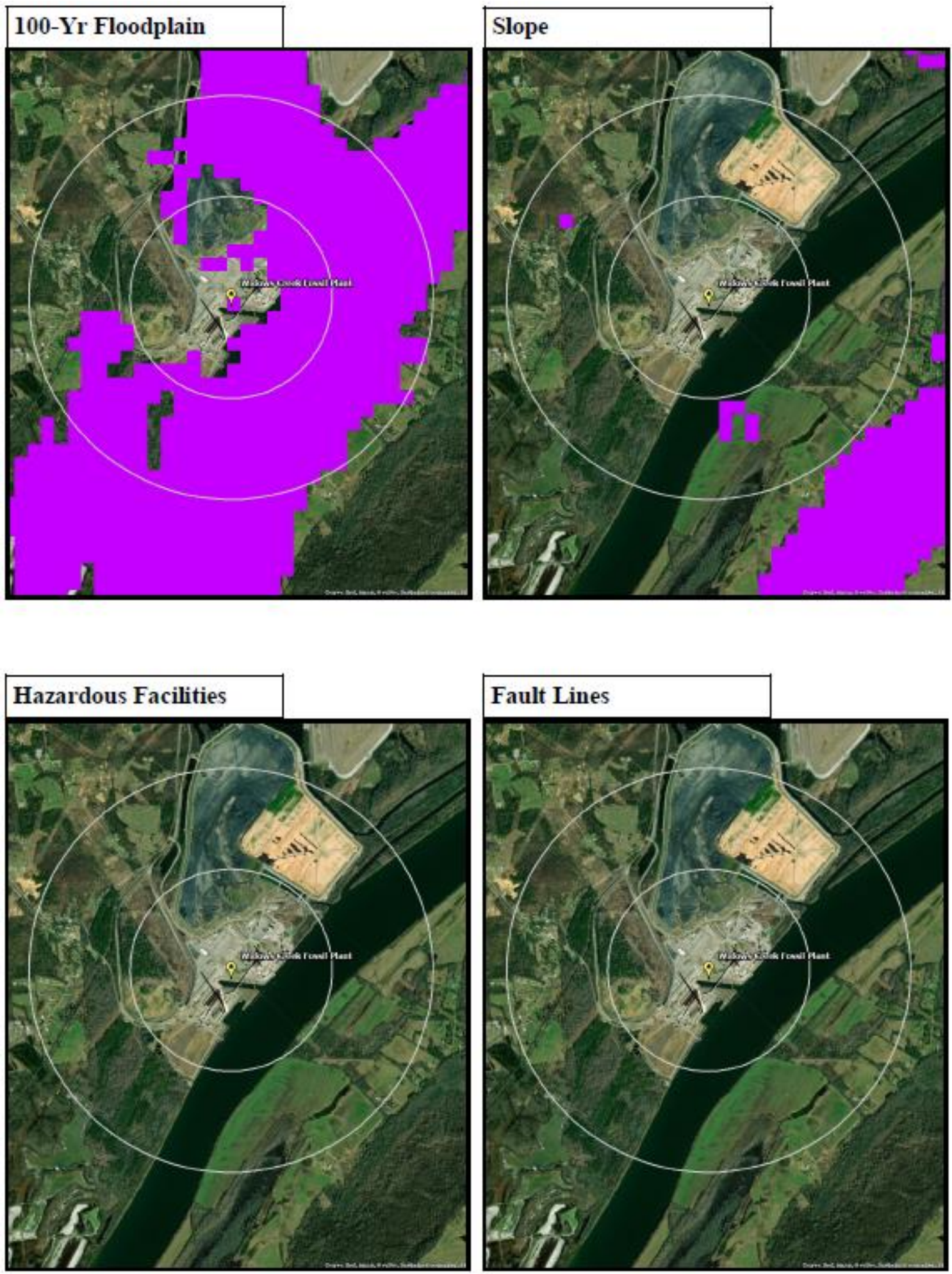

Figure 45. Widows Creek Fossil Plant siting criteria maps showing 100-year floodplain, slope, hazardous facilities, and fault lines. 

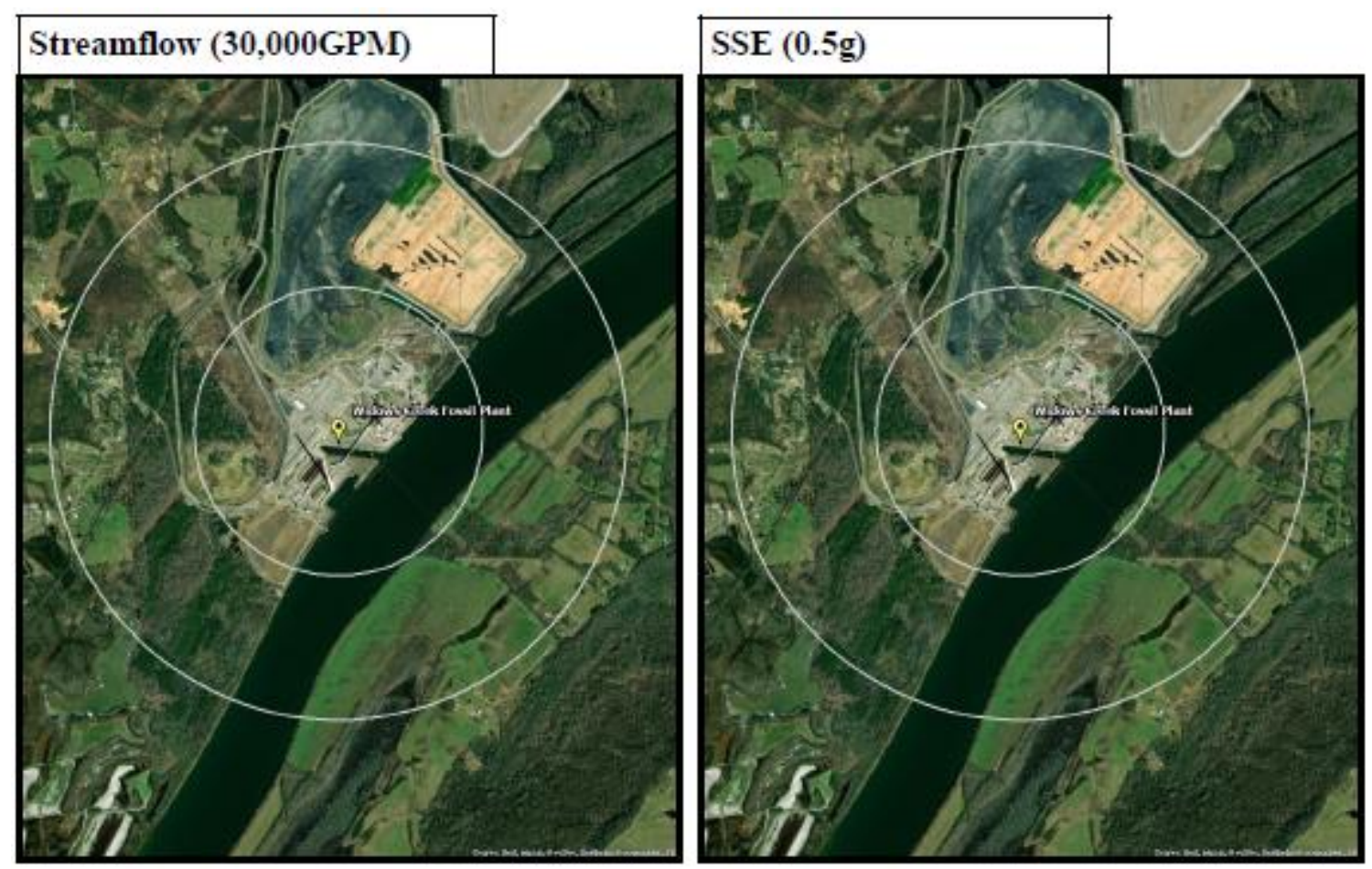

Figure 46. Widows Creek Fossil Plant siting criteria maps showing streamflow and SSE.

\subsubsection{Summary}

The only visual issues associated with this site are related to open water, slope, and floodplain, all of which are typically associated with a plant along a major waterway.

The Widows Creek Fossil Plant is about 4.5 miles east of Stevenson, Alabama. There are no population density concerns for the central Widows Creek site in relation to utilization of SMR or advanced nonLWR technology with a small source term associated with Stevenson.

As shown in Figure 43, the Widows Creek site is suitable to siting an SMR or an advanced non-LWR if supported by future regional load demand and if TVA retains sufficient land to support the technology of interest. 


\subsection{COLBERT FOSSIL PLANT}

The Colbert Fossil Plant is located on 1,300 acres on the south shore of Pickwick Lake near Muscle Shoals, Alabama, and the former Wilson Steam Plant. Five generating units were completed between 1951 and 1965. The station had a combined summer net generating capacity of 1,000 megawatts. The steam plant units were decommissioned between 2013 and 2016. Demolition and restoration are not expected to be complete until 2023. There are also 8 simple-cycle combustion turbines on the site with a net capacity of 392 megawatts [11]. Aerial imagery of the plant's topography is shown in Figure 47.

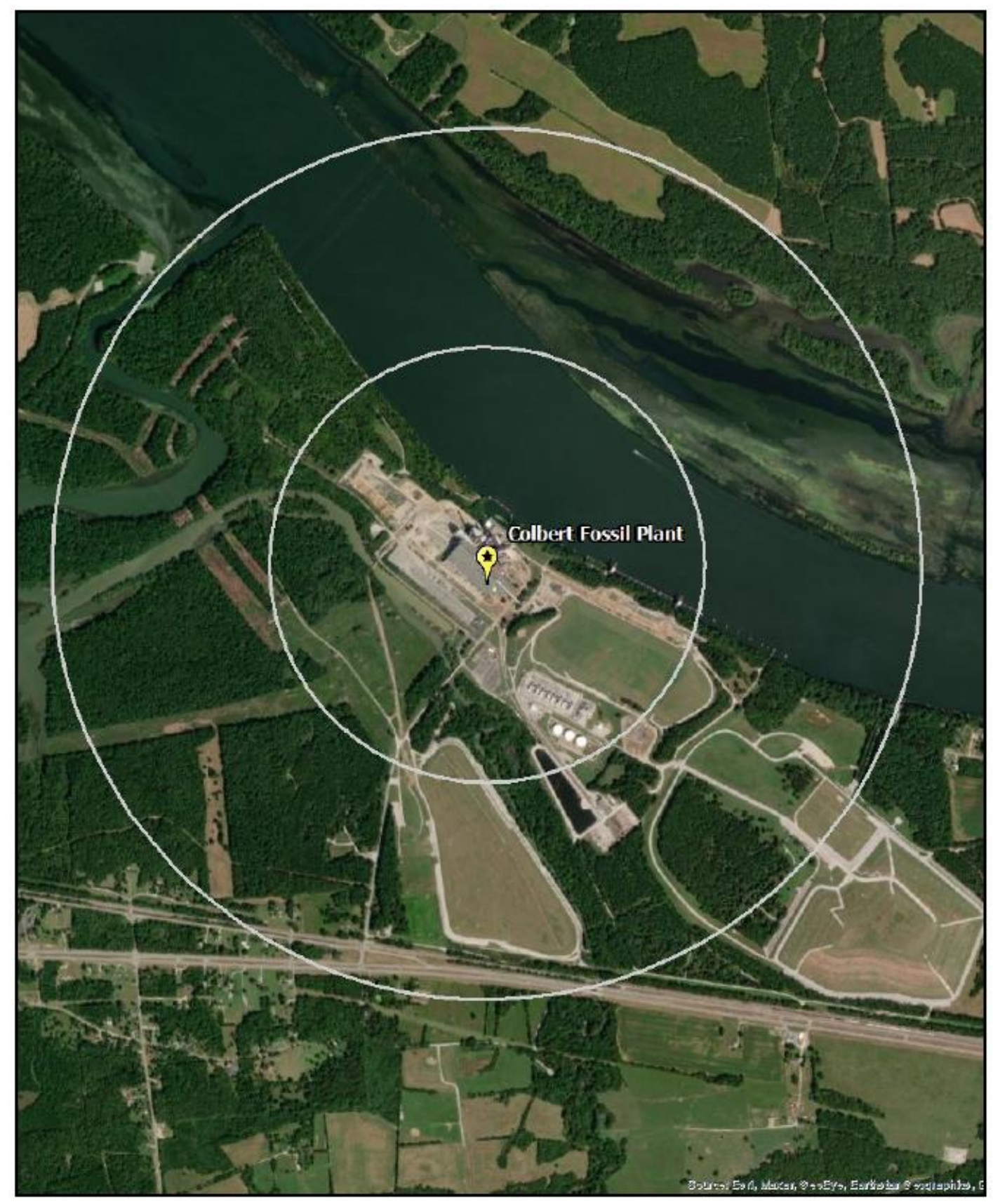

Figure 47. Satellite view of Colbert Fossil Plant proximity. 


\subsubsection{Evaluation}

The screening results for the Colbert site are listed in Table 10, and a composite map for the surrounding area is shown in Figure 48. The physical plant structures are located on land, with no siting issues. Maps of the individual SMR siting criteria based on selected input values are also included below.

Table 10. Colbert Fossil Plant siting criteria summary

\begin{tabular}{|c|}
\hline \multicolumn{2}{|c|}{ Screening Criteria Overview } \\
\hline Site: Colbert Fossil Plant \\
\hline
\end{tabular}

\begin{tabular}{|c|c|c|c|c|c|c|c|c|c|}
\hline \multicolumn{10}{|c|}{ Screening Criteria Summary Bar } \\
\hline \multicolumn{2}{|c|}{ No Siting Issue } & \multicolumn{4}{|c|}{ Partial Siting Issue } & & \multicolumn{3}{|c|}{ Full Siting Issue } \\
\hline $\begin{array}{l}\text { Inside } \\
\text { the } 0.5 \\
\text { mile } \\
\text { Radius } \\
\end{array}$ & \begin{tabular}{c|} 
Pop \\
Density
\end{tabular} & \begin{tabular}{|l|l|} 
Wet: & $\begin{array}{c}\text { Protected } \\
\text { Lands } \\
\text { lands }\end{array}$ \\
\end{tabular} & Landslide & $\begin{array}{l}100-\text { yr } \\
\text { Flood- } \\
\text { plain }\end{array}$ & \begin{tabular}{|l|} 
Slope \\
$(18 \%)$
\end{tabular} & $\begin{array}{c}\text { Hazardous } \\
\text { Facilities }\end{array}$ & $\begin{array}{l}\text { Fault } \\
\text { Lines }\end{array}$ & $\begin{array}{l}\text { Stream- } \\
\text { flow } \\
(30 \mathrm{~K} \\
\text { GPM) } \\
\end{array}$ & $\begin{array}{l}\mathrm{SSE} \\
(0.5 \mathrm{~g})\end{array}$ \\
\hline \begin{tabular}{|l} 
Inside \\
the \\
0.6 to $1-$ \\
mile \\
Radius \\
\end{tabular} & \begin{tabular}{|c|} 
Pop \\
Density
\end{tabular} & \begin{tabular}{|l|l|}
$\begin{array}{l}\text { Wet- } \\
\text { lands }\end{array}$ \\
Landsected
\end{tabular} & Landslide & $\begin{array}{l}\text { 100-yr } \\
\text { Flood- } \\
\text { plain }\end{array}$ & $\begin{array}{l}\text { Slope } \\
(18 \%)\end{array}$ & \begin{tabular}{|c|} 
Hazardous \\
Facilities \\
\end{tabular} & $\begin{array}{l}\text { Fault } \\
\text { Lines }\end{array}$ & $\begin{array}{l}\text { Stream- } \\
\text { flow } \\
\text { (30K } \\
\text { GPM) }\end{array}$ & $\begin{array}{c}\text { SSE } \\
(0.5 \mathrm{~g})\end{array}$ \\
\hline \multicolumn{10}{|c|}{ Screening Criteria Table } \\
\hline \multicolumn{6}{|c|}{ Criteria } & \multicolumn{4}{|c|}{ Value } \\
\hline \multicolumn{6}{|c|}{ Population Density within 4 miles } & \multicolumn{4}{|c|}{$>500$ (people/square mile) } \\
\hline \multicolumn{6}{|c|}{ Wetlands and Open water are excluded } & \multicolumn{4}{|c|}{-} \\
\hline \multicolumn{6}{|c|}{ Protected lands are excluded } & \multicolumn{4}{|c|}{-} \\
\hline \multicolumn{6}{|c|}{ Land with moderate/high landslide hazard susceptibility are excluded } & \multicolumn{4}{|c|}{-} \\
\hline \multicolumn{6}{|c|}{ Land that lies within a 100 -year floodplain is excluded } & \multicolumn{4}{|c|}{ - } \\
\hline \multicolumn{6}{|l|}{ Slope } & \multicolumn{4}{|c|}{$>18 \%\left(\sim 10^{\circ}\right)$} \\
\hline \multicolumn{6}{|c|}{$\begin{array}{l}\text { Land located in proximity to hazardous facilities } \\
\text { (Airport - 5mi; Oil Refinenes - 1mi; and Military Bases - } 1 \mathrm{mi} \text { ) }\end{array}$} & \multicolumn{4}{|c|}{-} \\
\hline \multicolumn{6}{|c|}{ Land too close to identified fault lines is avoided } & \multicolumn{4}{|c|}{ - } \\
\hline \multicolumn{6}{|c|}{ Streamflow within 20 miles } & \multicolumn{4}{|c|}{$\geq 30,000 \mathrm{gpm}$} \\
\hline \multicolumn{6}{|c|}{ Safe-shutdown earthquake peak ground acceler ation } & \multicolumn{4}{|c|}{$\geq 0.5 \mathrm{~g}$} \\
\hline
\end{tabular}




\section{Site Characterization: Composite Map}

\section{Site: Colbert Fossil Plant $\quad$ State: AL}

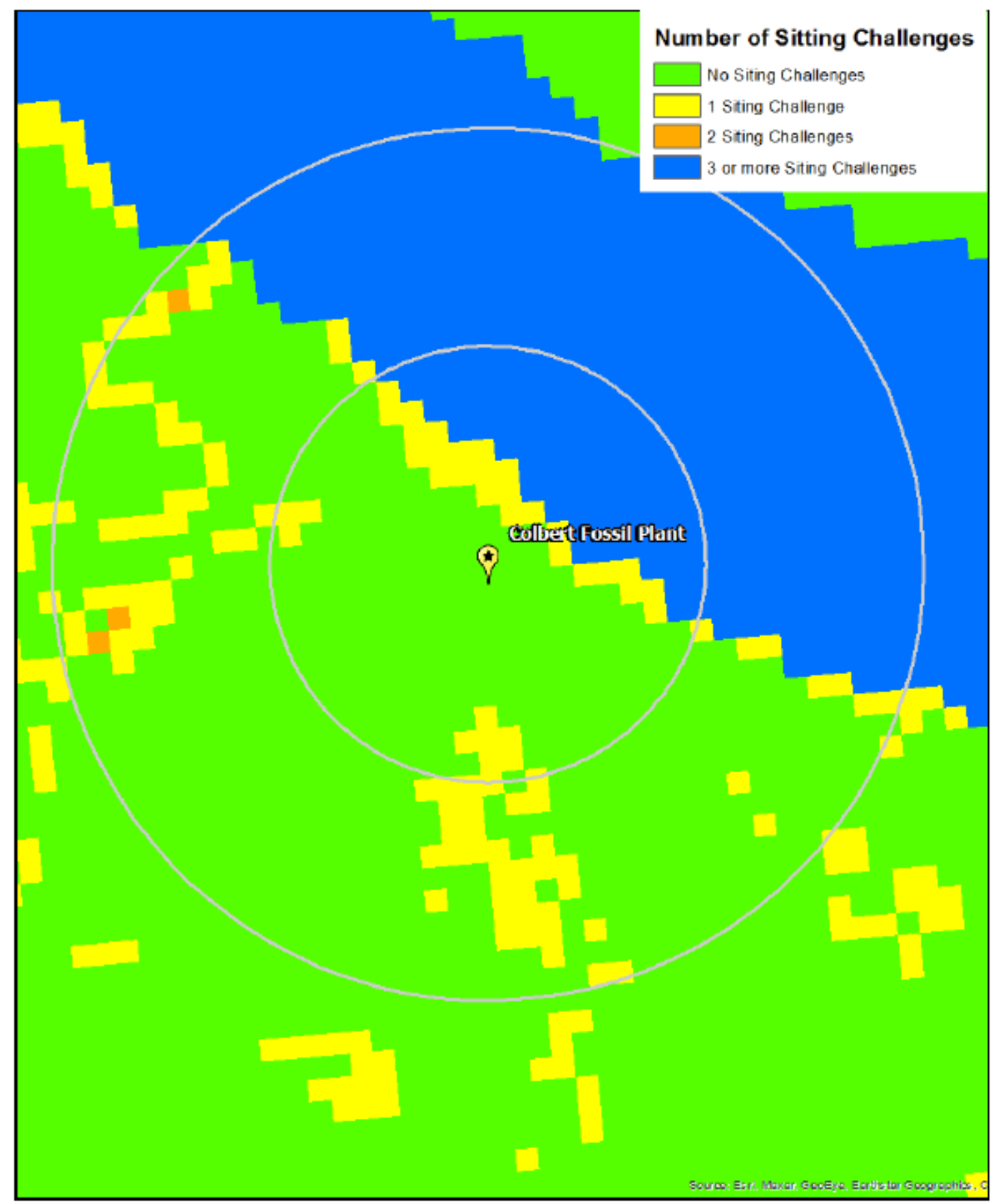

Figure 48. Colbert Fossil Plant composite map. 

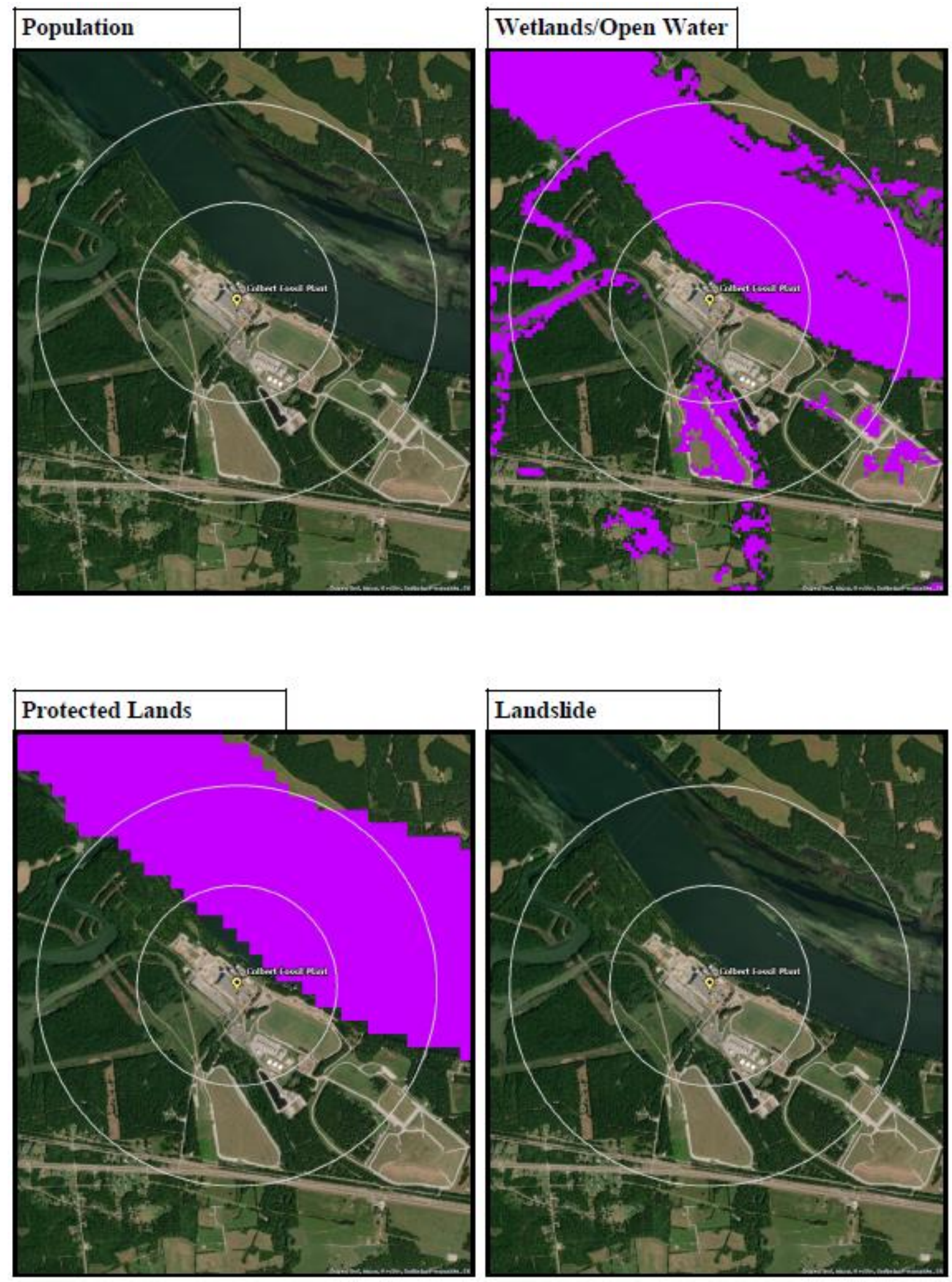

Figure 49. Colbert Fossil Plant siting criteria maps showing population, wetlands/open water, protected lands, and landslide. 

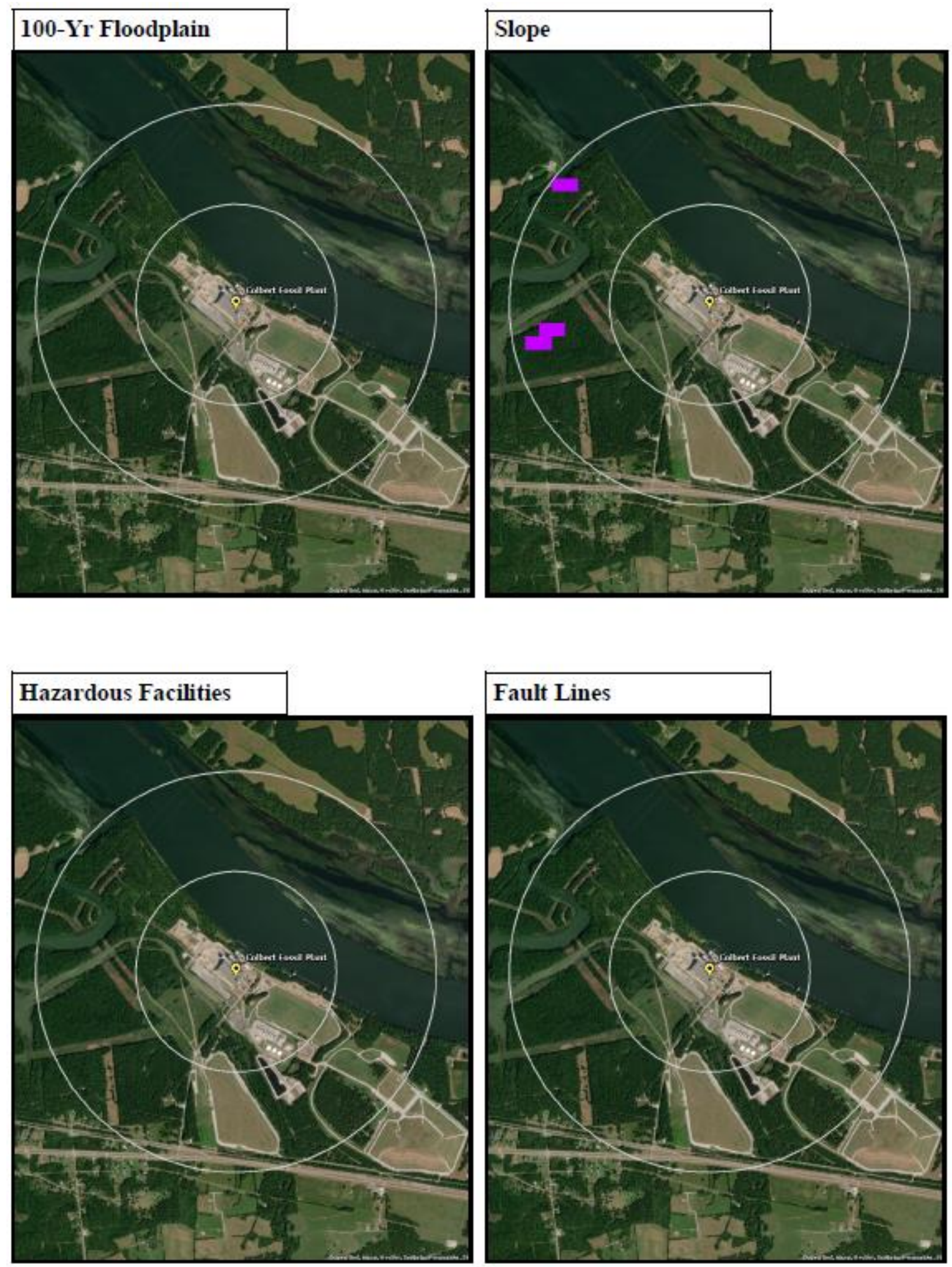

Figure 50. Colbert Fossil Plant siting criteria maps showing 100-year floodplain, slope, hazardous facilities, and fault lines. 

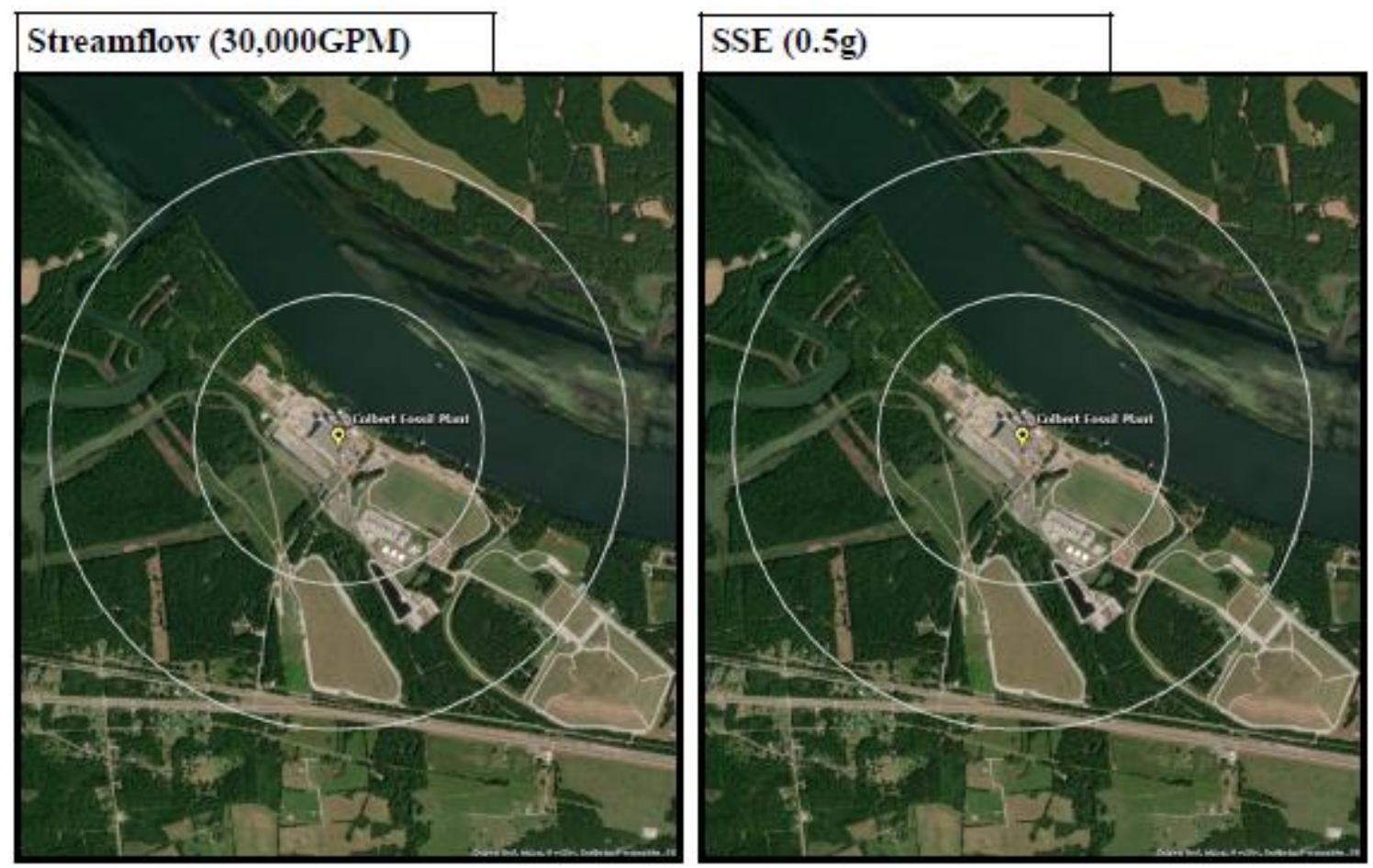

Figure 51. Colbert Fossil Plant siting criteria maps showing streamflow and SSE.

\subsubsection{Summary}

The only visual issues associated with this site are related to open water, which is typically associated with a plant along a major waterway. Pickwick Lake is also protected.

The Colbert Fossil Plant is about 8 miles west of Muscle Shoals, Alabama, and 13 miles downriver from the former Wilson Steam Plant. There are no population density concerns for the central Colbert site in relation to utilization of SMR or advanced non-LWR technology with a small source term associated with Muscle Shoals.

As shown in Figure 48, the Colbert site is suitable for siting an SMR or an advanced non-LWR if supported by future regional load demand and if TVA retains sufficient land to support the technology of interest. 


\subsection{JOHNSONVILLE FOSSIL PLANT}

The Johnsonville Fossil Plant is located on 720 acres on the Tennessee River near Waverly, Tennessee. Ten generating units were completed between 1951 and 1959. The station had a combined summer net generating capacity of 1,500 megawatts. The steam plant units were decommissioned between 2015 and 2017. Demolition and restoration are in the planning stage. There are also 20 simple-cycle combustion turbines on the site with a net capacity of 1,269 megawatts [11]. Aerial imagery of the plant's topography is shown in Figure 52.

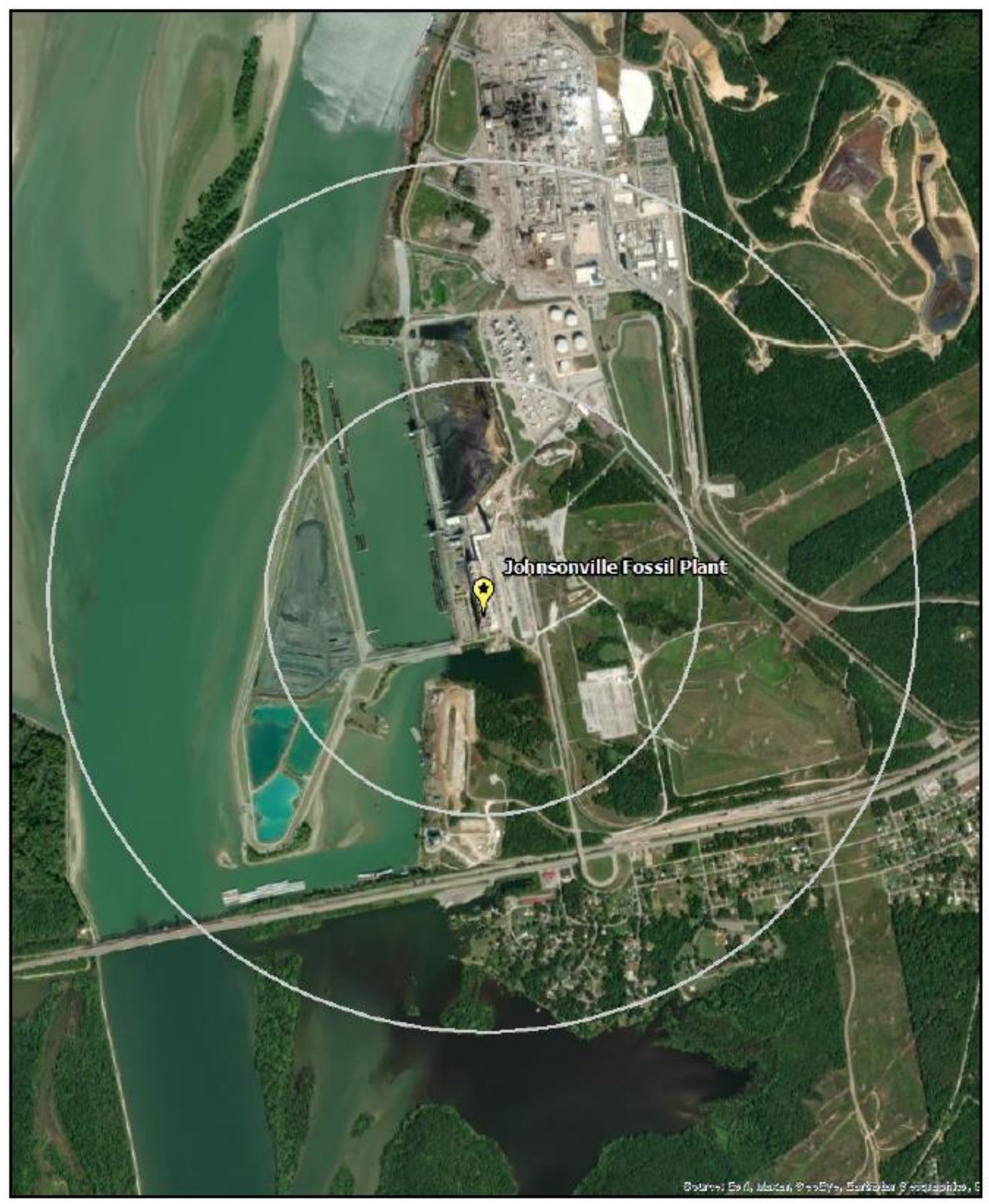

Figure 52. Satellite view of Johnsonville Fossil Plant proximity. 


\subsubsection{Evaluation}

The screening results for the Johnsonville site are listed in Table 11, and a composite map for the surrounding area is shown in Figure 53. The physical plant structures are located on land, with no siting issues. Maps of the individual SMR siting criteria based on selected input values are also provided below.

Table 11. Johnsonville Fossil Plant siting criteria summary

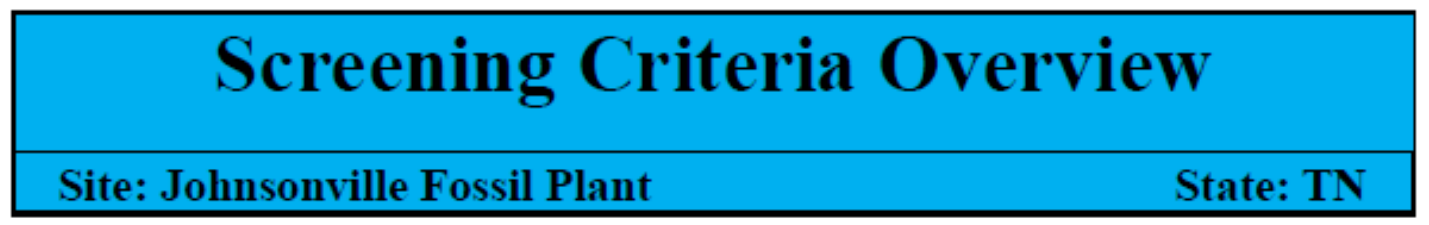

\begin{tabular}{|c|c|c|c|c|c|c|c|c|c|c|}
\hline \multicolumn{11}{|c|}{ Screening Criteria Summary Bar } \\
\hline \multicolumn{3}{|c|}{ No Siting Issue } & \multicolumn{4}{|c|}{ Partial Siting Issue } & & \multicolumn{3}{|c|}{ Full Siting Issue } \\
\hline $\begin{array}{c}\text { Inside } \\
\text { the } 0.5 \\
\text { mile } \\
\text { Radius } \\
\end{array}$ & $\begin{array}{c}\text { Pop } \\
\text { Density }\end{array}$ & \begin{tabular}{|l|} 
Wet- \\
lands \\
\end{tabular} & \begin{tabular}{c|c|} 
Protected \\
Lands
\end{tabular} & Landslide & $\begin{array}{c}\text { 100-yr } \\
\text { Flood- } \\
\text { plain }\end{array}$ & \begin{tabular}{|l|} 
Slope \\
$(18 \%)$
\end{tabular} & \begin{tabular}{|c|} 
Hazardous \\
Facilities
\end{tabular} & $\begin{array}{l}\text { Fault } \\
\text { Lines }\end{array}$ & 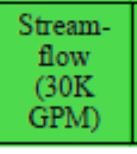 & $\begin{array}{l}\text { SSE } \\
(0.5 \mathrm{~g})\end{array}$ \\
\hline \begin{tabular}{|c|} 
Inside \\
the \\
0.6 to $1-$ \\
mile \\
Radius \\
\end{tabular} & $\begin{array}{c}\text { Pop } \\
\text { Density }\end{array}$ & \begin{tabular}{l|} 
Wet- \\
lands
\end{tabular} & \begin{tabular}{|r|} 
Protected \\
Iands
\end{tabular} & Landslide & $\begin{array}{l}100-\mathrm{y} \\
\text { Flood- } \\
\text { plain }\end{array}$ & $\begin{array}{l}\text { Slope } \\
(18 \%) \\
\end{array}$ & \begin{tabular}{|c|}
$\begin{array}{c}\text { Hazardous } \\
\text { Facilities }\end{array}$ \\
\end{tabular} & $\begin{array}{l}\text { Fault } \\
\text { Lines }\end{array}$ & $\begin{array}{l}\text { Stream- } \\
\text { flow } \\
\text { (30K } \\
\text { GPM) }\end{array}$ & $\begin{array}{c}\text { SSE } \\
(0.5 \mathrm{~g})\end{array}$ \\
\hline \multicolumn{11}{|c|}{ Screening Criteria Table } \\
\hline \multicolumn{7}{|c|}{ Criteria } & \multicolumn{4}{|c|}{ Value } \\
\hline \multicolumn{7}{|c|}{ Population Density within 4 miles } & \multicolumn{4}{|c|}{$>500($ people/square mile) } \\
\hline \multicolumn{7}{|c|}{ Wetlands and Open water are excluded } & \multicolumn{4}{|c|}{-} \\
\hline \multicolumn{7}{|c|}{ Protected lands are excluded } & \multicolumn{4}{|c|}{-} \\
\hline \multicolumn{7}{|c|}{ Land with moderate/high landslide hazard susceptibility are excluded } & \multicolumn{4}{|c|}{ - } \\
\hline \multicolumn{7}{|c|}{ Land that lies within a 100 -year floodplain is excluded } & \multicolumn{4}{|c|}{-} \\
\hline \multicolumn{7}{|l|}{ Slope } & \multicolumn{4}{|c|}{$>18 \%\left(\sim 10^{\circ}\right)$} \\
\hline \multicolumn{7}{|c|}{$\begin{array}{l}\text { Land located in proximity to hazardous facilities } \\
\text { (Airport - } 5 \mathrm{mi} \text {; Oil Refineries - } 1 \mathrm{mi} \text {; and Military Bases - } 1 \mathrm{mi} \text { ) }\end{array}$} & \multicolumn{4}{|c|}{-} \\
\hline \multicolumn{7}{|c|}{ Land too close to identified fault lines is avoided } & \multicolumn{4}{|c|}{ - } \\
\hline \multicolumn{7}{|c|}{ Streamflow within 20 miles } & \multicolumn{4}{|c|}{$\geq 30,000 \mathrm{gpm}$} \\
\hline Safe-shutc & own earthe & quake pea & k ground ac & celeration & & & & $\geq 0$ & & \\
\hline
\end{tabular}




\section{Site Characterization: Composite Map}

Site: Johnsonville Fossil Plant

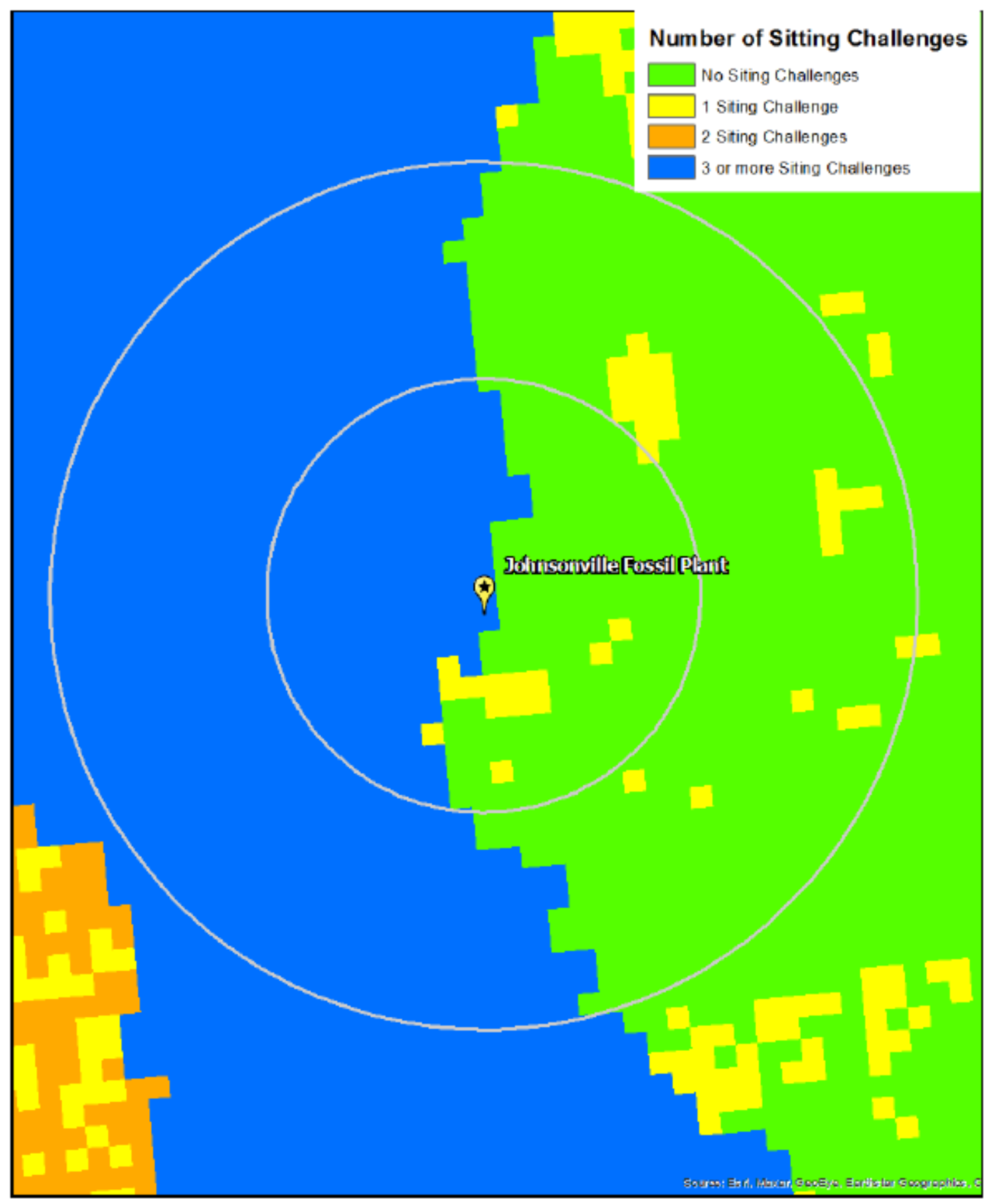

Figure 53. Johnsonville Fossil Plant composite map.
State: TN 

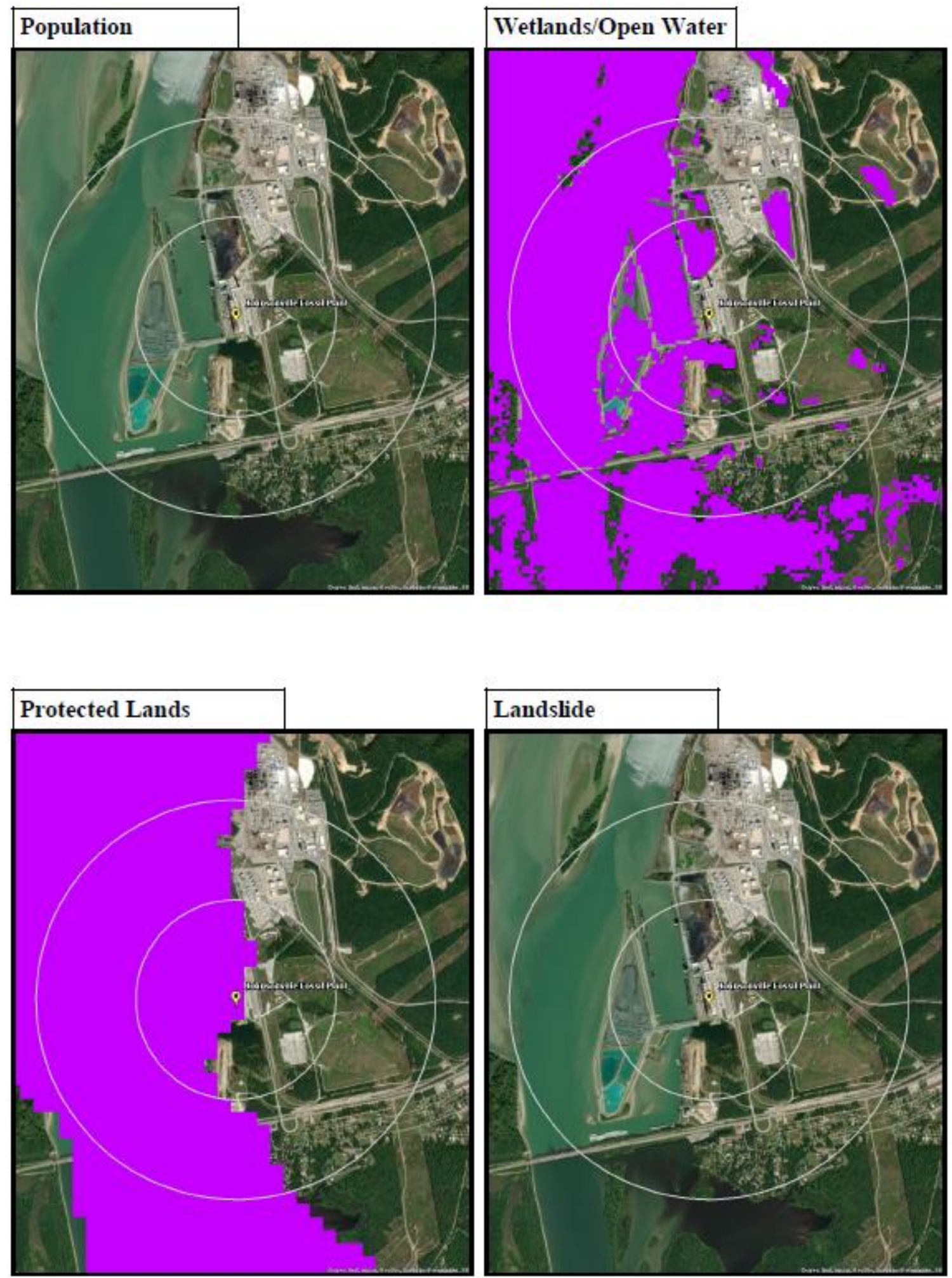

Figure 54. Johnsonville Fossil Plant composite maps showing population, wetlands/open water, protected lands, and landslide. 

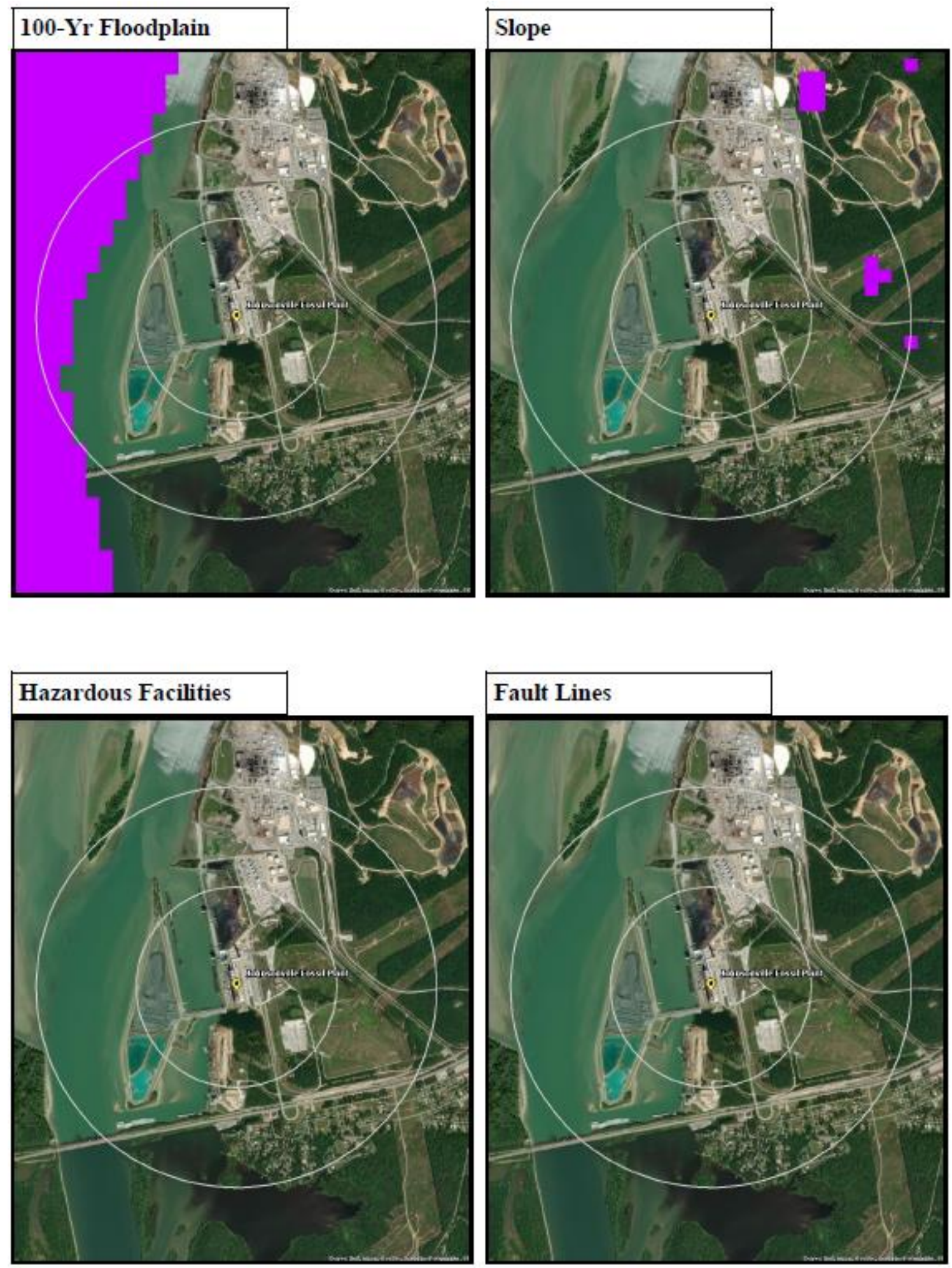

Figure 55. Johnsonville Fossil Plant composite maps showing 100-year floodplain, slope, hazardous facilities, and fault lines. 


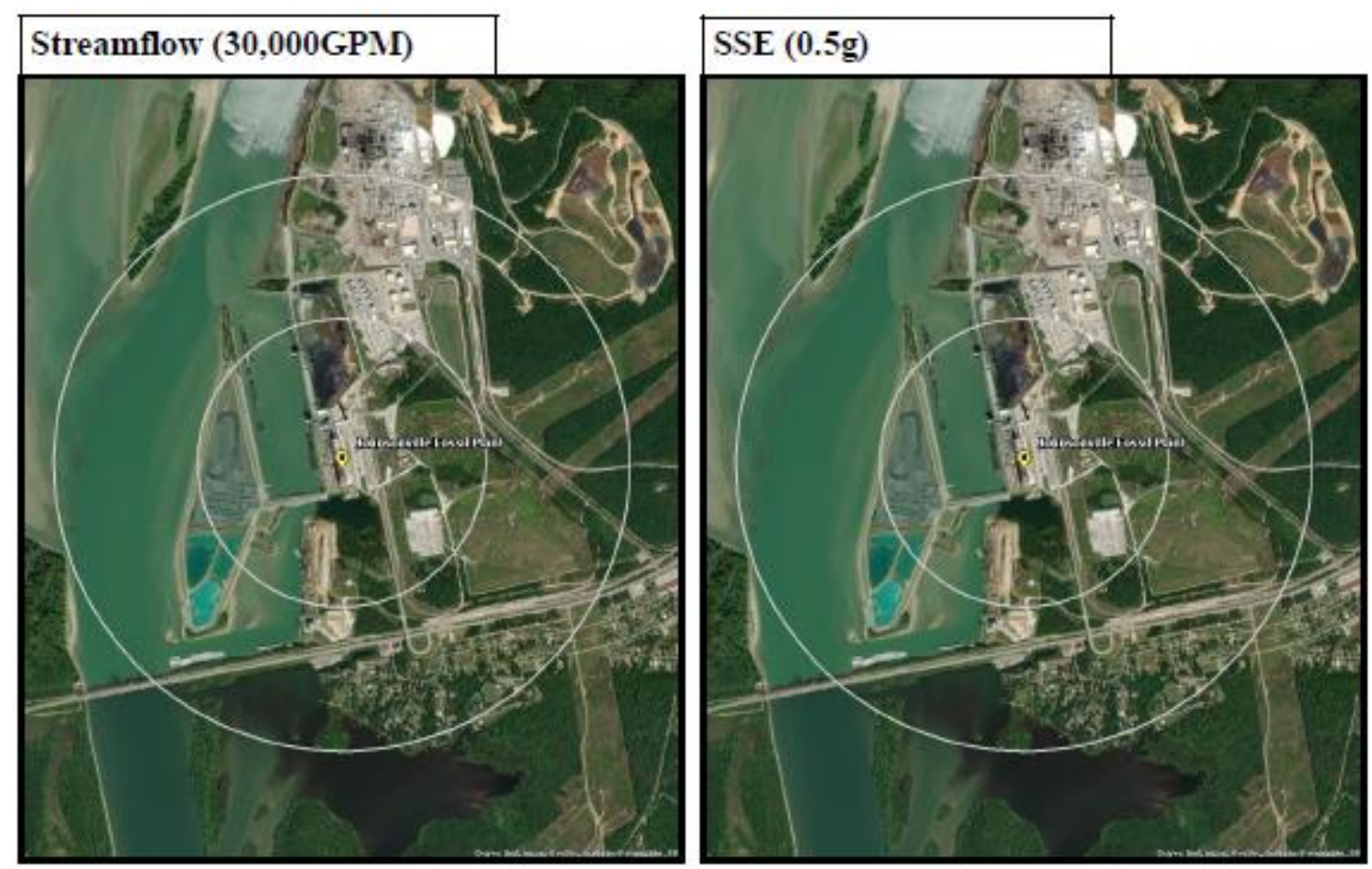

Figure 56. Johnsonville Fossil Plant composite maps showing streamflow and SSE.

\subsubsection{Summary}

The only visual issues associated with this site are related to open water, slope, and floodplain, all of which are typically associated with a plant along a major waterway. The Tennessee River is also protected in this area.

The Johnsonville Fossil Plant is about 11 miles west of Waverly, Tennessee. There are no population density concerns for the central Johnsonville site in relation to utilization of SMR or advanced non-LWR technology with a small source term associated with Waverly.

As shown in Figure 53, the Johnsonville site is suitable for siting an SMR or an advanced non-LWR if supported by future regional load demand and if TVA retains sufficient land to support the technology of interest. 


\subsection{ALLEN FOSSIL PLANT}

The Allen Fossil Plant is located on 500 acres on McKellar Lake outside Memphis, Tennessee. Three generating units were completed in 1959. The station had a combined summer net generating capacity of 741 megawatts. The steam plant units were decommissioned in 2018. Demolition and restoration are in the planning stage. There are also 20 gas combustion turbines on the site with a net capacity of 456 megawatts [11]. Aerial imagery of the plant's topography is shown in Figure 57.

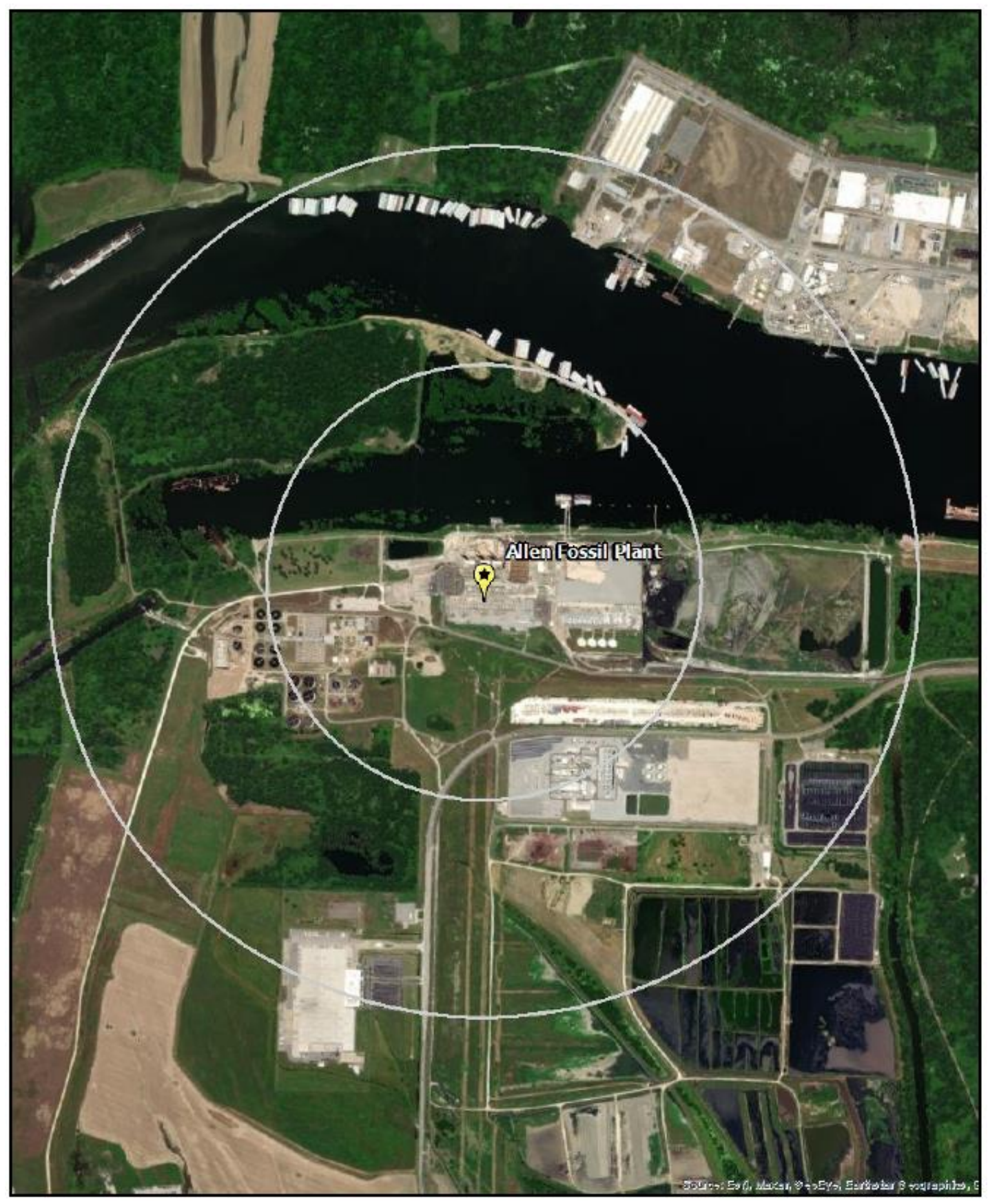

Figure 57. Satellite view of Allen Fossil Plant proximity. 


\subsubsection{Evaluation}

The screening results for the Allen site are listed in Table 12, and a composite map for the surrounding area is shown in Figure 58. The physical plant structures are located on land, with one siting issue. Maps of the individual SMR siting criteria based on selected input values are also provided below.

Table 12. Allen Fossil Plant siting criteria summary

\begin{tabular}{|cr|}
\hline \multicolumn{2}{|c|}{ Screening Criteria Overview } \\
\hline Site: Allen Fossil Plant & State: TN \\
\hline
\end{tabular}

\begin{tabular}{|c|c|c|c|c|c|c|c|c|c|c|}
\hline \multicolumn{3}{|c|}{ No Siting Issue } & \multicolumn{4}{|c|}{ Partial Siting Issue } & & \multicolumn{3}{|c|}{ Full Siting Issue } \\
\hline $\begin{array}{c}\text { Inside } \\
\text { the } 0.5 \\
\text { mile } \\
\text { Radius }\end{array}$ & $\begin{array}{c}\text { Pop } \\
\text { Density }\end{array}$ & $\begin{array}{l}\text { Wet- } \\
\text { lands }\end{array}$ & $\begin{array}{l}\text { Protected } \\
\text { Lands }\end{array}$ & Landslide & $\begin{array}{c}100-\mathrm{yI} \\
\text { Flood- } \\
\text { plain }\end{array}$ & $\begin{array}{l}\text { Slope } \\
(18 \%)\end{array}$ & \begin{tabular}{c|} 
Hazardous \\
Facilities
\end{tabular} & $\begin{array}{l}\text { Fault } \\
\text { Lines }\end{array}$ & 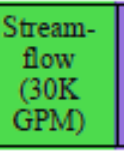 & $\begin{array}{c}\text { SSE } \\
(0.5 \mathrm{~g})\end{array}$ \\
\hline $\begin{array}{c}\text { Inside } \\
\text { the } \\
0.6 \text { to } 1- \\
\text { mile } \\
\text { Radius }\end{array}$ & $\begin{array}{c}\text { Pop } \\
\text { Density }\end{array}$ & $\begin{array}{l}\text { Wet- } \\
\text { lands }\end{array}$ & $\begin{array}{l}\text { Protected } \\
\text { Lands }\end{array}$ & Landslide & $\begin{array}{c}100-\mathrm{y} \\
\text { Flood- } \\
\text { plain }\end{array}$ & $\begin{array}{l}\text { Slope } \\
(18 \%)\end{array}$ & \begin{tabular}{c|} 
Hazardous \\
Facilities
\end{tabular} & $\begin{array}{l}\text { Fault } \\
\text { Lines }\end{array}$ & $\begin{array}{c}\text { Stream- } \\
\text { flow } \\
(30 \mathrm{~K} \\
\text { GPM) }\end{array}$ & $\begin{array}{c}\text { SSE } \\
(0.5 \mathrm{~g})\end{array}$ \\
\hline & & & Criteria & & & & & Val & & \\
\hline Population & Density v & ithin $4 \mathrm{~m}$ & niles & & & & $>5 C$ & (people/ & uare mile) & \\
\hline Wetlands & nd Open & vater are $e$ & excluded & & & & & - & & \\
\hline Protected & ands are $e$ & scluded & & & & & & - & & \\
\hline Land with & moderate/ & igh lands & slide hazard & susceptibili & lity are excl & luded & & - & & \\
\hline Land that & ies within & a 100 -yea & ar floodplai & is exclude & & & & - & & \\
\hline Slope & & & & & & & & $>18 \%$ & $\left.10^{\circ}\right)$ & \\
\hline $\begin{array}{l}\text { Land loca } \\
\text { (Airport - }\end{array}$ & $\begin{array}{l}\text { din prox } \\
\text { mi; Oil R }\end{array}$ & $\begin{array}{l}\text { mity to } h \\
\text { efineries - }\end{array}$ & $\begin{array}{l}\text { lazardous fa } \\
\text { - 1mi; and I }\end{array}$ & $\begin{array}{l}\text { cilities } \\
\text { Military Bas }\end{array}$ & ses-1 mi) & & & - & & \\
\hline Land too $\mathrm{C}$ & lose to ide & atified fau & ult lines is a & voided & & & & - & & \\
\hline Streamflor & within 2 & miles & & & & & & $\geq 30,00$ & $\mathrm{pm}$ & \\
\hline Safe-shutc & own earth & luake pea & k ground ac & celeration & & & & $\geq 0$ & & \\
\hline
\end{tabular}




\section{Site Characterization: Composite Map \\ Site: Allen Fossil Plant \\ State: TN}

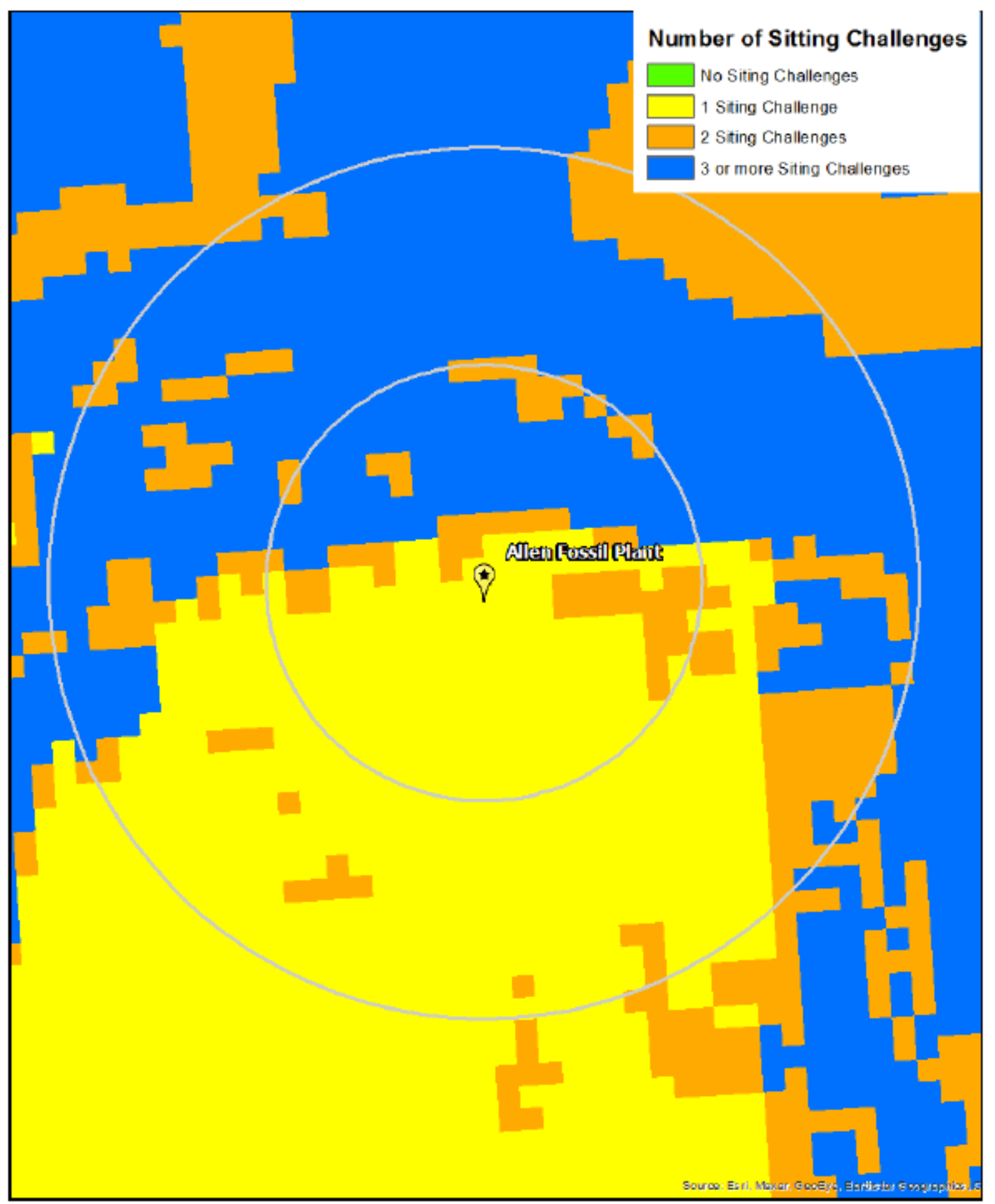

Figure 58. Allen Fossil Plant composite map. 

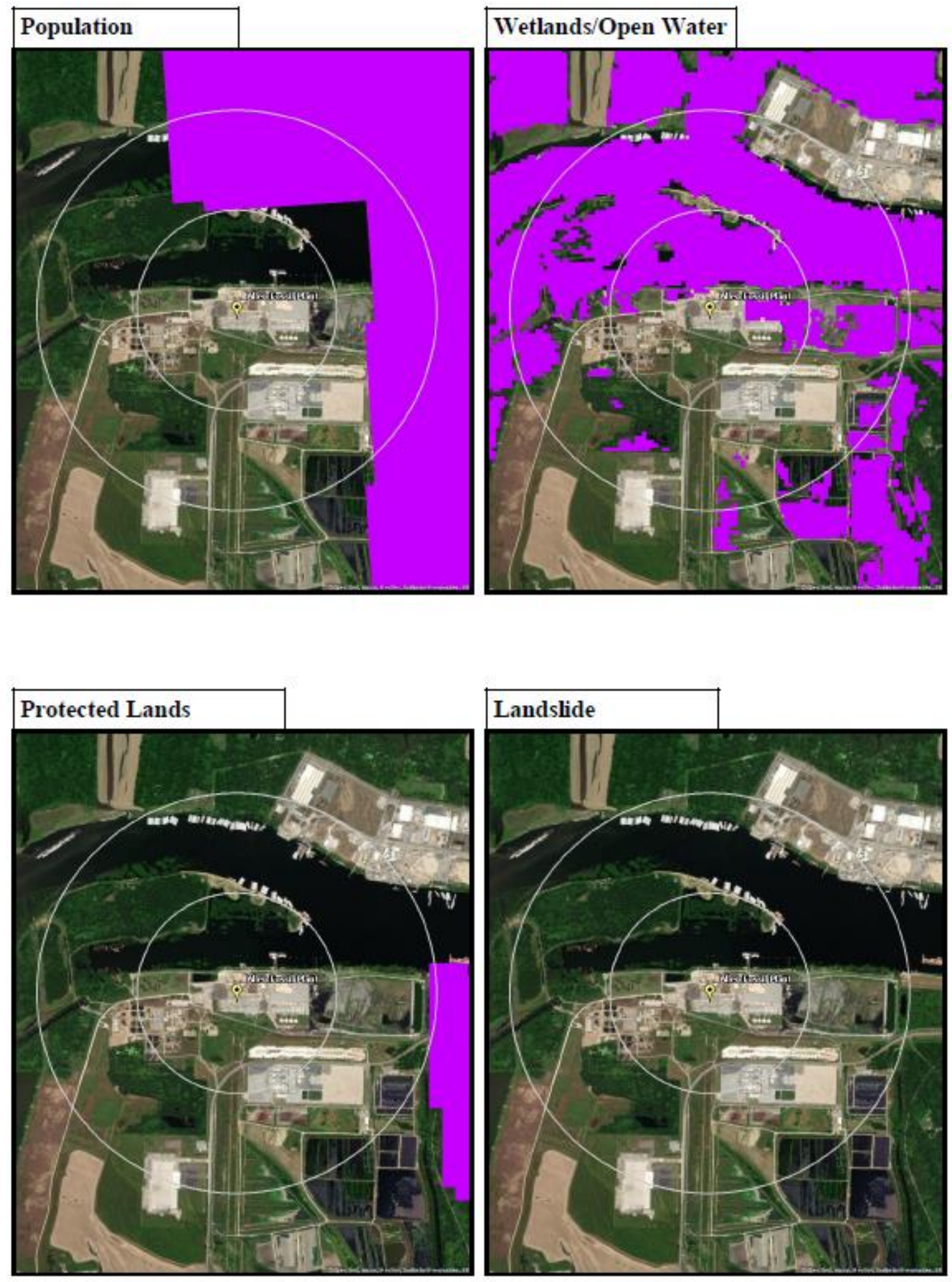

Figure 59. Allen Fossil Plant composite maps showing population, wetlands/open water, protected lands, and landslide. 

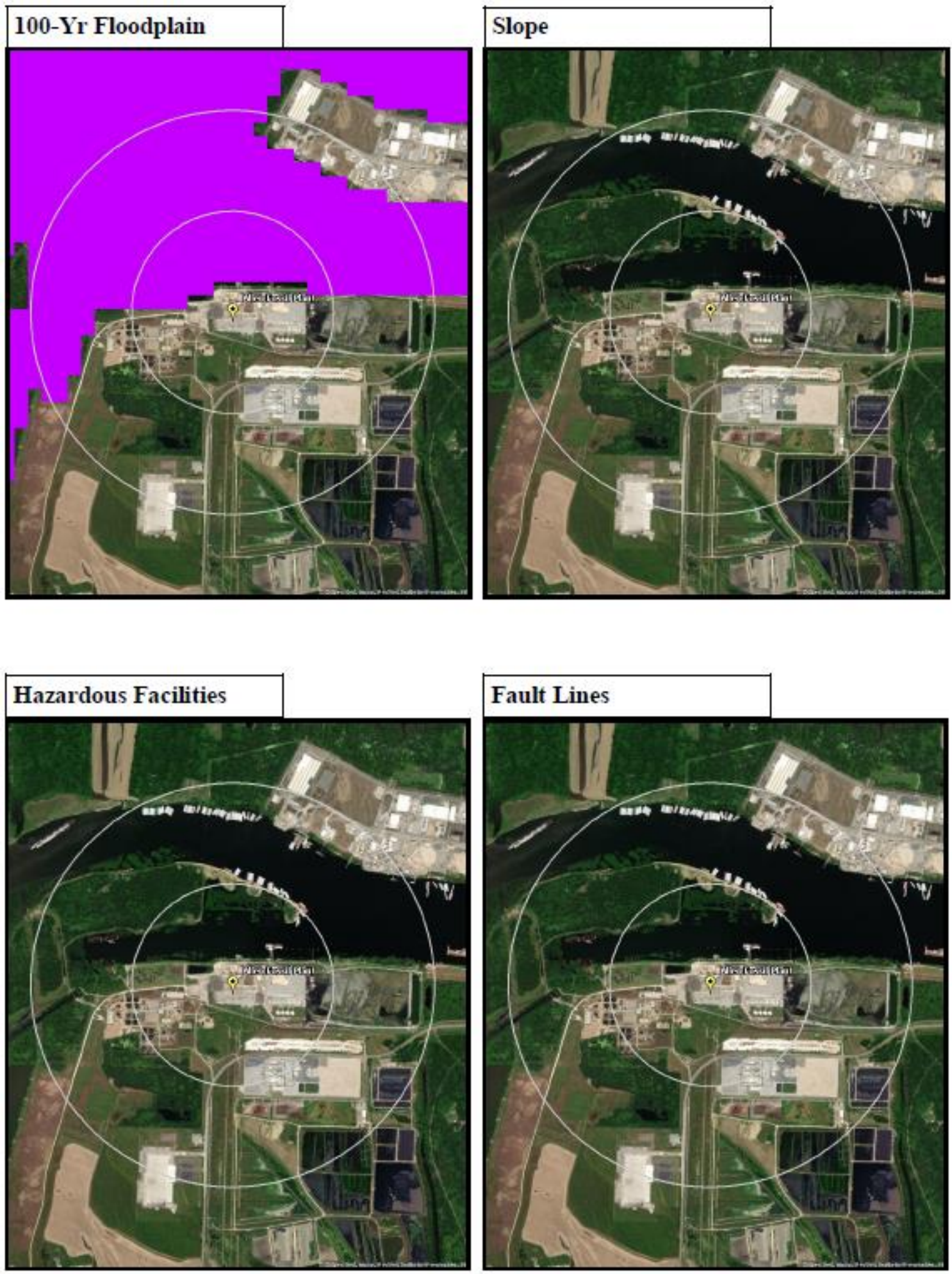

Figure 60. Allen Fossil Plant composite maps showing 100-year floodplain, slope, hazardous facilities, and fault lines. 

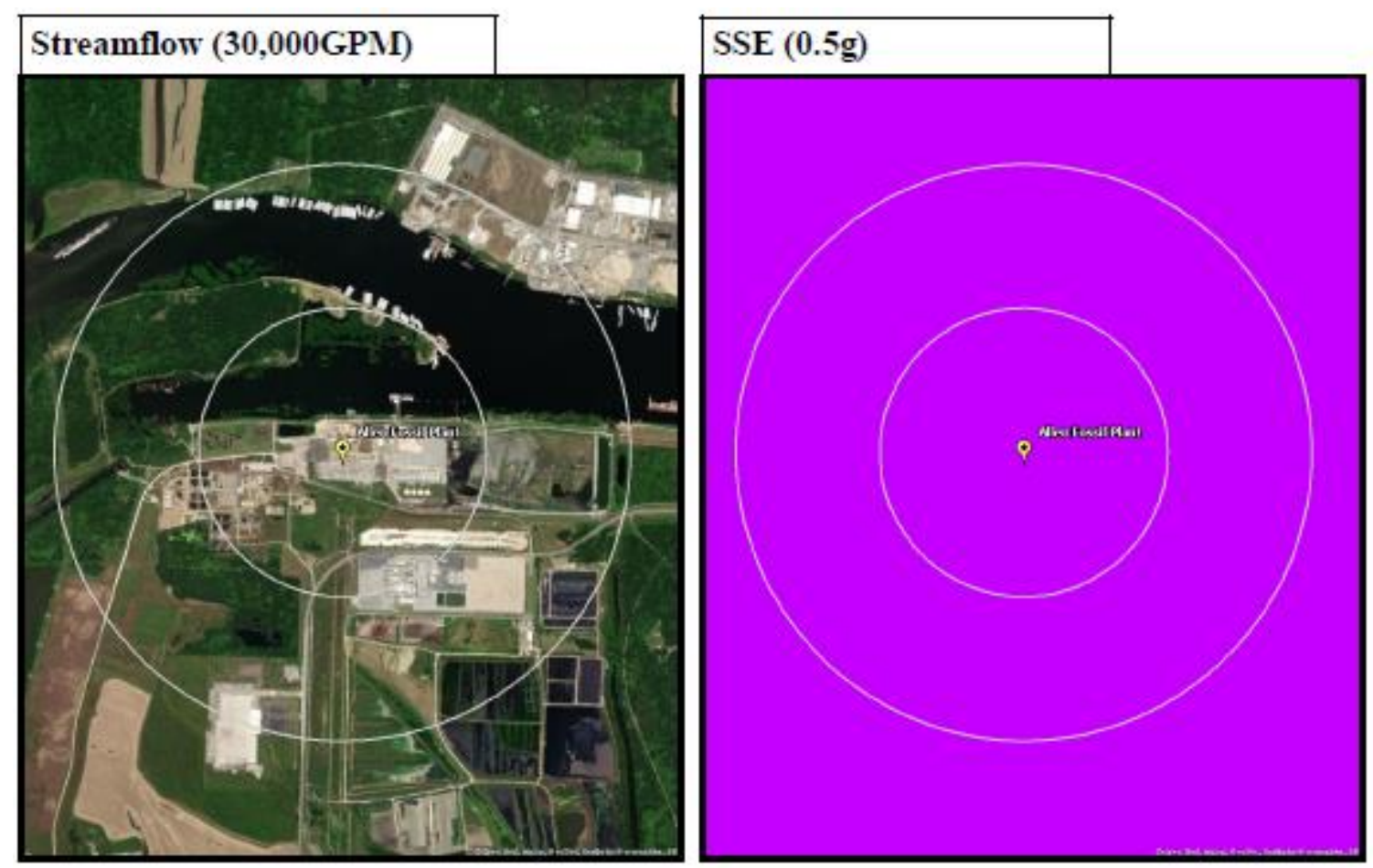

Figure 61. Allen Fossil Plant composite maps showing streamflow and SSE.

\subsubsection{Summary}

Open water and floodplain are flagged but are typically associated with a plant along a major waterway. The T.O. Fuller State Park is protected to the east of the site.

The Allen Fossil Plant is about 5 miles west of Memphis, Tennessee. As a result, there are population density concerns north and east of the central Allen site in relation to utilization of SMR or advanced nonLWR technology with a small source term.

The predominant risk to siting in this area is safe shutdown earthquake due to proximity to the New Madrid seismic zone. Engineering that would allow an advanced non-LWR to demonstrate public health and safety at peak ground acceleration (2\% chance in a 50-year return period) at values greater than $0.5 \mathrm{~g}$ will be necessary to propose siting in this region.

As shown in Figure 58, the Allen site is less suitable for siting an SMR or an advanced non-LWR than other current or former coal-fired stations because there is no space that has passed the default siting parameters. Given the recent construction of gas turbine capacity at the site, the proximity to Memphis, and the seismic concerns, the Allen site would be less desirable for an SMR or an advanced non-LWR. 


\subsection{PARADISE FOSSIL PLANT}

The Paradise Fossil Plant is located on approximately 3,500 acres on the Green River near Drakesboro, Kentucky. Three generating units were completed between 1963 and 1970. The station had a combined summer net generating capacity of 2,453 megawatts. The steam plant units were decommissioned between 2017 and 2020. Demolition and restoration are in the planning stage. There are also 3 combustion turbines on the site with a net capacity of 1,100 megawatts [11]. Aerial imagery of the plant's topography is shown in Figure 62.

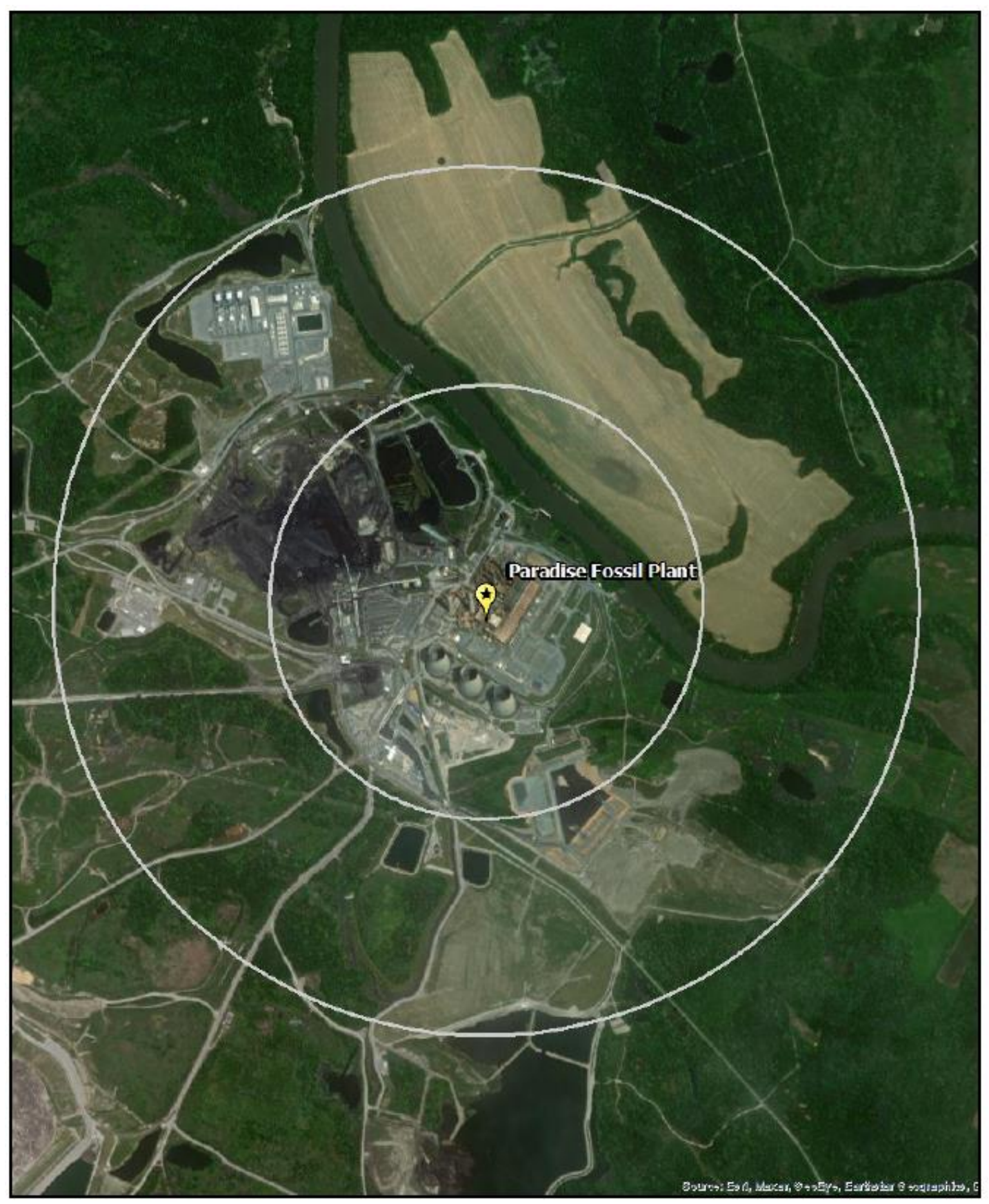

Figure 62. Satellite view of Paradise Fossil Plant proximity. 


\subsubsection{Evaluation}

The screening results for the Paradise site are listed in Table 13, and a composite map for the surrounding area is shown in Figure 63. The physical plant structures are located on land with no siting issues. Maps of the individual SMR siting criteria based on selected input values are also provided below.

Table 13. Paradise Fossil Plant siting criteria summary

\begin{tabular}{|lc|}
\hline \multicolumn{2}{|c|}{ Screening Criteria Overview } \\
\hline Site: Paradise Fossil Plant & State: KY \\
\hline
\end{tabular}

\begin{tabular}{|c|c|c|c|c|c|c|c|c|c|c|}
\hline \multicolumn{11}{|c|}{$\underset{\text { (Colored Boxes indicate Screening Results) }}{\operatorname{Screening} \text { Criteria Summary }}$} \\
\hline \multicolumn{3}{|c|}{ No Siting Issue } & \multicolumn{4}{|c|}{ Partial Siting Issue } & & \multicolumn{3}{|c|}{ Full Siting Issue } \\
\hline $\begin{array}{l}\text { Inside } \\
\text { the } 0.5 \\
\text { mile } \\
\text { Radius }\end{array}$ & \begin{tabular}{|c|} 
Pop \\
Density
\end{tabular} & $\begin{array}{l}\text { Wet- } \\
\text { lands }\end{array}$ & \begin{tabular}{|c|} 
Protected \\
Lands
\end{tabular} & Landslide & $\begin{array}{l}100-\text { yr } \\
\text { Flood- } \\
\text { plain }\end{array}$ & \begin{tabular}{|l|} 
Slope \\
$(18 \%)$
\end{tabular} & \begin{tabular}{|c|} 
Hazardous \\
Facilities
\end{tabular} & $\begin{array}{l}\text { Fault } \\
\text { Lines }\end{array}$ & \begin{tabular}{|c|} 
Stream- \\
flow \\
(30K \\
GPM)
\end{tabular} & $\begin{array}{l}\text { SSE } \\
(0.5 \mathrm{~g})\end{array}$ \\
\hline $\begin{array}{l}\text { Inside } \\
\text { the } \\
0.6 \text { to } 1- \\
\text { mile } \\
\text { Radius }\end{array}$ & \begin{tabular}{|c|} 
Pop \\
Density
\end{tabular} & \begin{tabular}{|l|} 
Wet- \\
lands
\end{tabular} & \begin{tabular}{c|} 
Protected \\
Lands
\end{tabular} & Landslide & $\begin{array}{l}100 \text {-yr } \\
\text { Flood- } \\
\text { plain }\end{array}$ & $\begin{array}{l}\text { Slope } \\
(18 \%)\end{array}$ & \begin{tabular}{|c|} 
Hazardous \\
Facilities
\end{tabular} & $\begin{array}{l}\text { Fault } \\
\text { Lines }\end{array}$ & \begin{tabular}{|c|} 
Stream- \\
flow \\
(30K \\
GPM)
\end{tabular} & $\begin{array}{c}\text { SSE } \\
(0.5 \mathrm{~g})\end{array}$ \\
\hline \multicolumn{11}{|c|}{ Screening Criteria Table } \\
\hline \multicolumn{7}{|c|}{ Criteria } & \multicolumn{4}{|c|}{ Value } \\
\hline \multicolumn{7}{|c|}{ Population Density within 4 miles } & \multicolumn{4}{|c|}{$>500$ (people/square mile) } \\
\hline \multicolumn{7}{|c|}{ Wetlands and Open water are excluded } & \multicolumn{4}{|c|}{-} \\
\hline \multicolumn{7}{|c|}{ Protected lands are excluded } & \multicolumn{4}{|c|}{-} \\
\hline \multicolumn{7}{|c|}{ Land with moderate/high landslide hazard susceptibility are excluded } & \multicolumn{4}{|c|}{-} \\
\hline \multicolumn{7}{|c|}{ Land that lies within a 100 -year floodplain is excluded } & \multicolumn{4}{|c|}{ - } \\
\hline \multicolumn{7}{|l|}{ Slope } & \multicolumn{4}{|c|}{$>18 \%\left(\sim 10^{\circ}\right)$} \\
\hline \multicolumn{7}{|c|}{$\begin{array}{l}\text { Land located in proximity to hazardous facilities } \\
\text { (Airport - 5mi; Oil Refineries - } 1 \mathrm{mi} \text {; and Military Bases }-1 \mathrm{mi} \text { ) }\end{array}$} & \multicolumn{4}{|c|}{-} \\
\hline \multicolumn{7}{|c|}{ Land too close to identified fault lines is avoided } & \multicolumn{4}{|c|}{-} \\
\hline \multicolumn{7}{|c|}{ Streamflow within 20 miles } & \multicolumn{4}{|c|}{$\geq 30,000 \mathrm{gpm}$} \\
\hline \multicolumn{7}{|c|}{ Safe-shutdown earthquake peak ground acceleration } & \multicolumn{4}{|c|}{$\geq 0.5 \mathrm{~g}$} \\
\hline
\end{tabular}




\section{Site Characterization: Composite Map}

Site: Paradise Fossil Plant

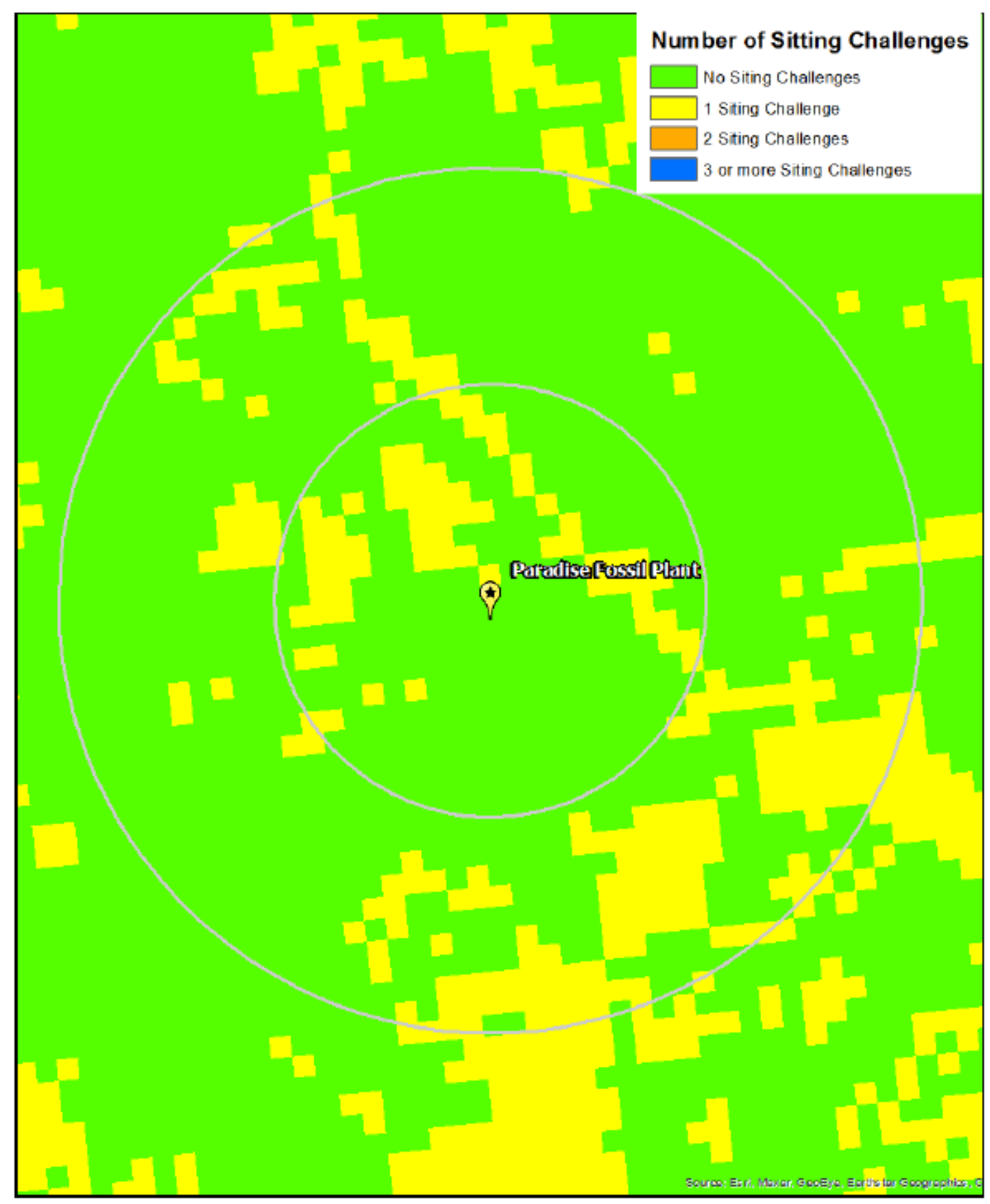

Figure 63. Paradise Fossil Plant composite map.

\section{State: KY}



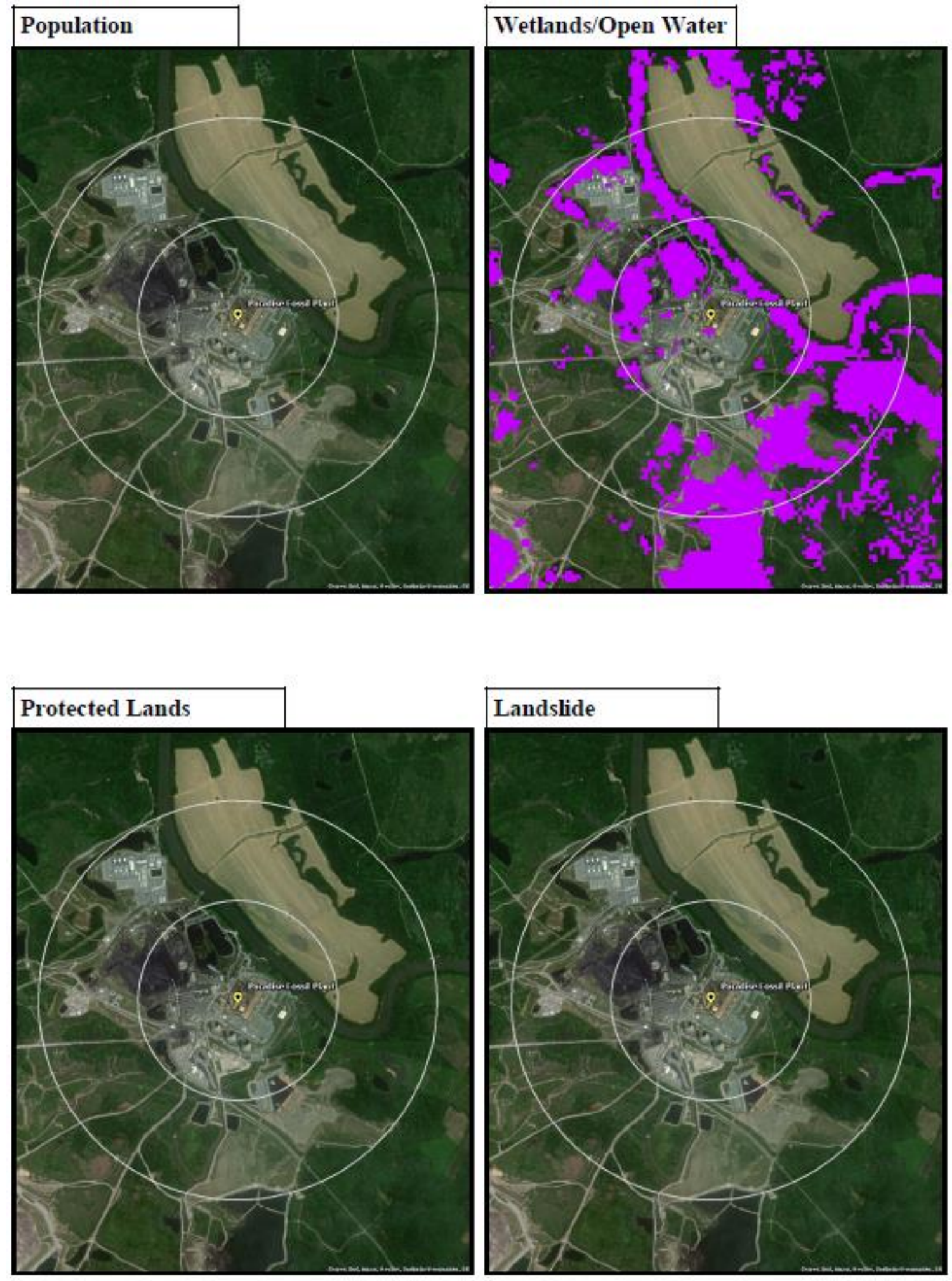

Figure 64. Paradise Fossil Plant composite maps showing population, wetlands/open water, protected lands, and landslide. 

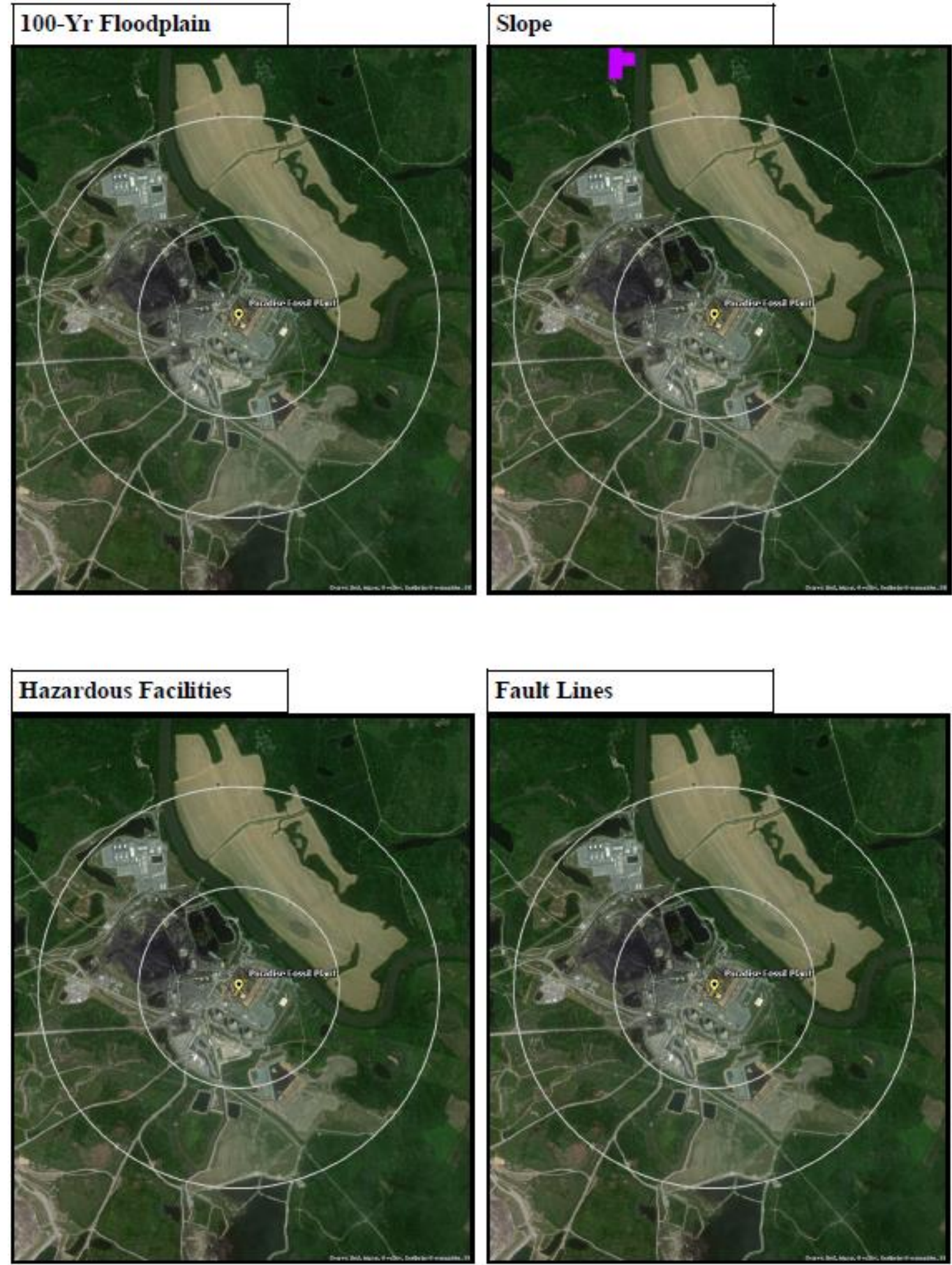

Figure 65. Paradise Fossil Plant composite maps showing 100-year floodplain, slope, hazardous facilities, and fault lines. 

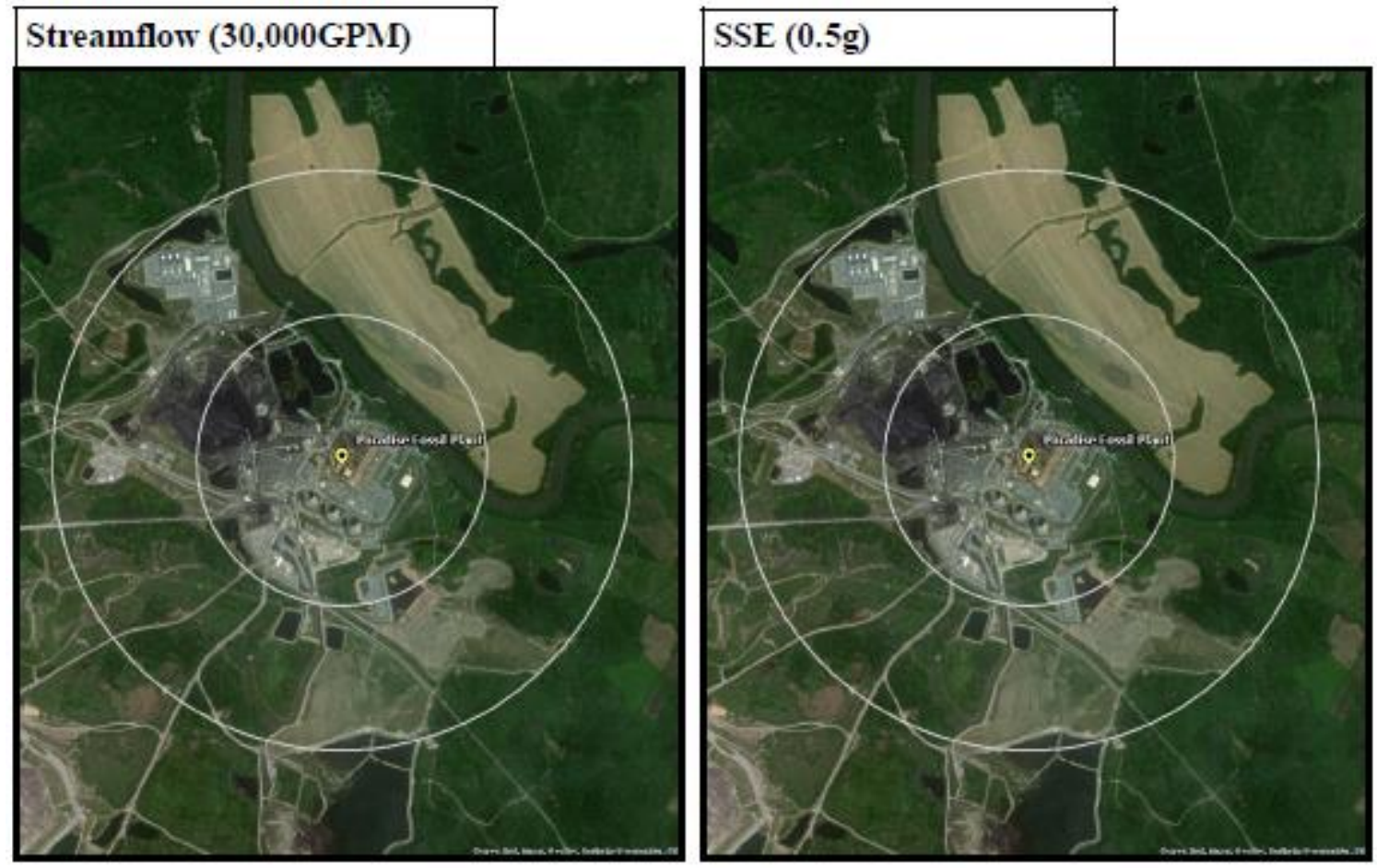

Figure 66. Paradise Fossil Plant composite maps showing streamflow and SSE.

\subsubsection{Summary}

The only visual issues associated with this site are related to open water and minimal slope, both of which are typically associated with a plant along a major waterway.

The Paradise Fossil Plant is about 5 miles northeast of Drakesboro, Kentucky. There are no population density concerns for the central Paradise site in relation to utilization of SMR or advanced non-LWR technology with a small source term associated with Drakesboro.

As shown in Figure 63, the Paradise site is suitable for siting an SMR or an advanced non-LWR if supported by future regional load demand and if TVA retains sufficient land to support the technology of interest. 


\section{OBSERVATIONS}

The 2019 TVA IRP signals that TVA is phasing out its coal-fired assets, but it will pursue license renewal options for its existing nuclear fleet while evaluating emerging nuclear technologies, including SMRs, as part of technology innovation efforts. This report analyzes the potential for backfitting SMRs and advanced non-LWR technologies at the current and former TVA coal plant sites.

There are five TVA coal-fired stations still operating. Two of the currently operating coal-fired stations are suitable for siting an SMR or an advanced non-LWR technology: the Cumberland site and the Gallatin site. Of these two stations, the Cumberland site may be the best choice for meeting demand, because the Gallatin site has additional gas-fired combined cycle capacity installed. The Shawnee station is not recommended based on the seismic activity associated with the New Madrid seismic zone. The Bull Run and Kingston stations have noted siting issues that could possibly be addressed with additional engineering effort and technology selection. However, the proximity of the Bull Run and Kingston sites to the banked Clinch River site likely make that effort unnecessary.

There are eight former coal-fired stations in the TVA system. Only two of these sites have broad area siting parameter concerns: the Wilson site and the Allen site. The Wilson site has been transformed into a recreation area and would not be a good candidate for further consideration for a reactor backfit.

Likewise, the Allen site is near Memphis, and although it is not population excluded, there are seismic concerns at the site. The Allen site also recently added gas combustion turbine capacity. Therefore, the Allen site is not a good candidate for further consideration for a reactor backfit.

The remaining six former TVA coal-fired stations are all suitable for consideration for backfit of SMR or advanced non-LWR technology based on OR-SAGE analysis. The Watts Bar site has been demolished, but there is sufficient land, as well as a nuclear pedigree at the site, if projected energy demand supports consideration of additional nuclear capacity. The John Sevier and Widows Creek sites are both suitable for SMR or advanced non-LWR technology siting. However, TVA has announced plans to sell off excess land at these sites, which would hamper a reactor decision. Google has reportedly broken ground on a datacenter at the Widows Creek site. In addition, the John Sevier site now hosts an 880 MWe gas plant. The remaining three former coal-fired sites - Colbert, Johnsonville, and Paradise - are all suitable for SMR or advanced non-LWR technology siting and are regionally diverse (Alabama, Tennessee, and Kentucky). All three sites include some of the most recently decommissioned coal-fired units. However, all three of these sites also have some gas-turbine capacity to consider for future energy demand planning.

As expected, most of the current and former TVA coal plant sites are suitable for SMR or advanced nonLWR technology siting based on a site review using OR-SAGE. Many sites have alternative energy source uses, including hydroelectric, gas, and nuclear capabilities to consider for energy planning. Therefore, any future decision to add nuclear SMR or advanced non-LWR capacity will depend on technology economics and regional demand. TVA's plan to retain the land for generation purposes will also be a factor at many sites. With an otherwise flat capacity demand [4], the current interest in electrifying transportation will likely be a factor in any future TVA generation capacity decisions. Further coal site analyses supported by the DOE-NE SA\&I Campaign could clarify the potential for siting SMR or advanced non-LWR technology at other utilities in other regions of the country.

The analysis presented in this report demonstrates the capability of the OR-SAGE tool to rapidly inform and provide a clear visualization of siting assessments. OR-SAGE can readily be applied to assist TVA in any future decision making or to support a nationwide assessment of current and former coal stations and sites as part of a move to a low-carbon economy as proposed by the current administration. 


\section{REFERENCES}

1. US Energy Information Administration, "More Than 100 Coal-Fired Plants Have Been Replaced or Converted to Natural Gas Since 2011," Today in Energy, August 5, 2020, Today-InEnergy August 5.

2. US Energy Information Administration, "U.S. Coal-Fired Electricity Generation in 2019 Falls to 42-Year Low," Today in Energy, May 11, 2020, Today-In_Energy_May_11.

3. D. Gearino, "Inside Clean Energy: The Era of Fossil Fuel Power Plants is Rapidly Receding. Here is Their Life Expectancy," Inside Climate News, December 10, 2020, Inside-ClimateNews Dec 10.

4. TVA, “2019 Integrated Resource Plan,” 2019, https://www.tva.com/environment/environmentalstewardship/integrated-resource-plan.

5. R. J. Belles, O. A. Omitaomu, et al., Updated Application of Spatial Data Modeling and Geographical Information Systems (GIS) for Identification of Potential Siting Options for Small Modular Reactors, ORNL/TM-2012/403, ORNL, Oak Ridge, TN, September 2012, https://info.ornl.gov/sites/publications/Files/Pub39008.pdf

6. O. A. Omitaomu et al., "Adapting a GIS-Based Multicriteria Decision Analysis Approach for Evaluating New Power Generating Sites,” Applied Energy, Volume 96, 292-301, August 2012.

7. NRC, General Site Suitability Criteria for Nuclear Power Stations, RG 4.7, Revision 3, March 2014.

8. E. Rodwell (Project Manager), Siting Guide: Site Selection and Evaluation Criteria for an Early Site Permit Application, 1006878, Final Report, Electric Power Research Institute, March 2002.

9. R. J. Belles, O. A. Omitaomu, et al., Evaluation of Suitability of Selected Set of Coal Plant Sites for Repowering with Small Modular Reactors, ORNL/TM-2013/109, ORNL, Oak Ridge, TN, March 2013, https://www.osti.gov/biblio/1073000

10. TVA, "Coal," 2021, https://www.tva.com/energy/our-power-system/coal

11. TVA, "Plants of the Past," 2021, https://www.tva.com/energy/our-power-system/coal/plants-ofthe-past 
APPENDIX A. OR-SAGE Algebraic Methodology 



\section{APPENDIX A. OR-SAGE ALGEBRAIC METHODOLOGY}

The basic OR-SAGE methodology and the potential for nuclear siting capacity is well documented $[5,6]$. The methodology is briefly summarized in this appendix.

Specifically, OR-SAGE uses a map algebra approach. This approach divides the contiguous United States into $100 \times 100 \mathrm{~m}$ grids for a total of 700 million cells. With $K$ different types of siting criteria, a binary variable $x_{i j}^{k}$ is defined for each cell, where $x_{i j}^{k}=0$ when siting criteria $k$ for cell $(\mathrm{i}, \mathrm{j})$ satisfies the criteria threshold. Otherwise, $x_{i j}^{k}=1$. Therefore, the generation of suitable areas using map algebra formulation can be expressed as

$$
\min \left\{z_{i j}=\sum_{k=1}^{K} x_{i j}^{k}\right\}
$$

where $x_{i j}^{k} \in\{0,1\}, \forall k=1, \ldots, K ; i=1, \ldots, N ; j=1, \ldots, M$; that is,

$x_{i j}^{1}= \begin{cases}0, & \text { if population density in cell is }<500 \text { people per square mile, and } \\ 1, & \text { if population density in cell is } \geq 500 \text { people per square mile }\end{cases}$

$x_{i j}^{2}= \begin{cases}0, & \text { if cell is not a protected land } \\ 1, & \text { if cell is a protected land }\end{cases}$

$x_{i j}^{3}= \begin{cases}0, & \text { if SSE } \leq 0.2 \mathrm{~g} \\ 1, & \text { if SSE }>0.2 \mathrm{~g}\end{cases}$

$x_{i j}^{4}= \begin{cases}0, & \text { if cell is low landslide hazard } \\ 1, & \text { if cell is moderate or high landslide hazard }\end{cases}$

$x_{i j}^{5}= \begin{cases}0, & \text { if cell is not close to fault lines } \\ 1, & \text { if cell is close to fault lines }\end{cases}$

$x_{i j}^{6}= \begin{cases}0, & \text { if cell is not close to hazardous operations } \\ 1, & \text { if cell is close to hazardous operations }\end{cases}$ 
$x_{i j}^{7}= \begin{cases}0, & \text { if cell is not in } 100-\text { year floodplain region } \\ 1, & \text { if cell is in } 100-\text { year floodplain region }\end{cases}$

$x_{i j}^{8}= \begin{cases}0, & \text { if cell is not classified as wetlands or open water } \\ 1, & \text { if cell is classified as wetlands or open water }\end{cases}$

$x_{i j}^{9}= \begin{cases}0, & \text { if slope } \leq 18 \% \\ 1, & \text { if slope }>18 \%\end{cases}$

$x_{i j}^{10}= \begin{cases}0, & \text { if streamflow }>65,000 \text { galloans per minute } \\ 1, & \text { if streamflow } \leq 65,000 \text { galloans per minute }\end{cases}$

Finally, $z_{i j}$ is further classified as follows:

$\left\{\begin{array}{l}\text { if } z_{i j}=0 \stackrel{\text { yields }}{\longrightarrow} \text { land area suitable for siting a reactor } \\ \text { if } z_{i j}>0 \stackrel{\text { yields }}{\longrightarrow} \text { land area not suitable for siting a reactor }\end{array}\right.$

If $z_{i j}=1$, then one siting criterion is not satisfied. Similarly, if $z_{i j}=2$, then two siting criteria are not satisfied, and so on. A graphical representation of the matrix on a national scale is shown in Figure 1 in the main body of the report. This is called the composite map. Green areas are cells with $z_{i j}=0$; yellow areas are cells with $z_{i j}=1$; gold areas are cell with $z_{i j}=2$; and blue areas are cell with $z_{i j} \geq 3$. 


(n)

